\title{
FERNANDA BACCIOTTI
}

Fisiologia e formação de partículas lipídicas durante o crescimento da levedura Yarrowia lipolytica IMUFRJ 50682.

São Paulo 
FERNANDA BACCIOTTI

Fisiologia e formação de partículas lipídicas durante o crescimento da levedura Yarrowia lipolytica IMUFRJ 50682.

Dissertação apresentada à Escola Politécnica da Universidade de São Paulo como requisito para a obtenção do título de Mestre em Ciências.

Orientador: Andreas Karoly Gombert

São Paulo

2015 
FERNANDA BACCIOTTI

Fisiologia e formação de partículas lipídicas durante o crescimento da levedura Yarrowia lipolytica IMUFRJ 50682.

Dissertação apresentada à Escola

Politécnica da Universidade de São Paulo como requisito para a obtenção do título de Mestre em Ciências.

Área de Concentração: Engenharia Química

Orientador: Andreas Karoly Gombert 


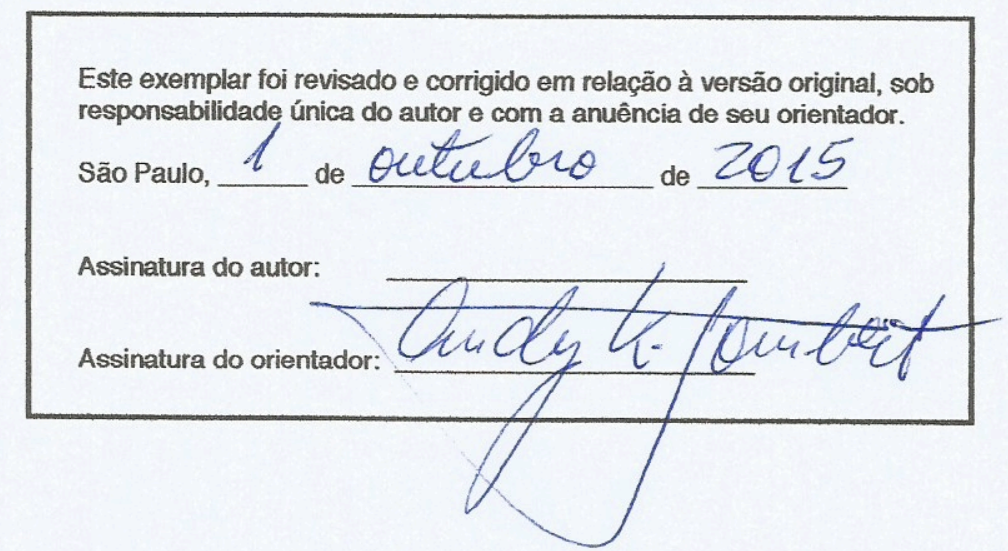

Catalogação-na-publicação

Bacciotti, Fernanda

Fisiologia e formação de partículas lipídicas durante o crescimento da levedura Yarrowia lipolytica IMUFRJ 50682. / F. Bacciotti -- versão corr. -- São Paulo, 2015

$123 p$.

Dissertação (Mestrado) - Escola Politécnica da Universidade de São Paulo. Departamento de Engenharia Química.

1.Yarrowia lipolytica 2.fisiologia microbiana 3.leveduras oleaginosas I.Universidade de São Paulo. Escola Politécnica. Departamento de Engenharia Química II.t. 
A minha mäe pelo apoio e amor incondicional, A $\mathcal{E}$ za, Benedito e Isolina pelo amor e por acreditarem sempre em mim, Ao Marcelo, Cassiano e Simiramis pelo apoio e carinho, Sem todos vocés eu não tería chegado onde estou! 


\section{AGRADECIMENTOS}

Ao meu orientador Prof. Dr. Andreas Karoly Gombert pela oportunidade concedida, pela paciência e compreensão frente às dificuldades encontradas ao longo desse projeto.

Ao Prof. Aldo Tonso pelo apoio e suporte em todas as etapas desse projeto e também pelas horas e horas ajudando com os problemas técnicos.

A Prof. Monica Montero Lomeli por me receber na UFRJ e me auxiliar no desenvolvimento das metodologias do projeto.

A minha mãe, Marcelo e os meus sogros pelo incentivo e auxílio durante todo o mestrado.

Ao Pedro Henrique Santos Oliveira pelo auxílio no desenvolvimento e na execução dos experimentos até então inéditos no grupo, pelas boas discussões científicas e não científicas que tornaram o nosso trabalho mais fácil e prazeroso, pela amizade e por me aguentar no dia a dia.

Às técnicas de laboratório Orlinda Azevedo e Andréa Silva pelo dedicado trabalho na manutenção e ordem dos laboratórios, pela ajuda durante o desenvolvimento dos experimentos, pela esperança dada nas dificuldades, pela descontração, amizade e carinho.

A todos os meus colegas de laboratório, em especial: Bianca, Bruno Labatte, Bruno Oishi, Felipe, Letícia Veloso, Kelly, Larrisa, Luís Franco, Carolina Bellão, Luiz Castel, Thiago Basso, Mariana, Paula, Sebatian, Rafael e Wesley, pois cada um contribuiu de alguma forma com o desenvolvimento do meu trabalho, também pela amizade, carinho e companheirismo.

E finalmente a Fapesp pela concessão da bolsa de mestrado que permitiu a minha estadia em São Paulo para a realização do mestrado. 
"Murphy era otimista"

Arthur Charles Clarke 


\section{RESUMO}

A levedura Yarrowia lipolytica tem sido muito investigada, especialmente por ser um microrganismo oleaginoso, ou seja, capaz de acumular grandes quantidades de lipídios, o que ocorre majoritariamente em organelas denominadas partículas lipídicas. Estes lipídios apresentam várias potenciais aplicações biotecnológicas, como por exemplo na produção de óleo microbiano (single cell oil) e na produção de biodiesel. Durante este projeto de mestrado, objetivou-se estudar a fisiologia de duas linhagens da levedura $Y$. lipolytica, sendo uma tradicionalmente estudada pela comunidade científica internacional (linhagem w29) e outra isolada da Baía da Guanabara, no Rio de Janeiro (linhagem IMUFRJ 50682). Foram realizados cultivos em frascos agitados tipo Erlenmeyer com defletores tampados com algodão (volume total $500 \mathrm{~mL}$, volume de meio $100 \mathrm{~mL}, 28{ }^{\circ} \mathrm{C}$ e 200 rotações por minuto), durante os quais foi possível: 1) escolher um meio de cultivo de composição totalmente definida, com tiamina como único fator de crescimento, adequado a estudos de fisiologia quantitativa com esta levedura; 2) verificar que $Y$. lipolytica não é capaz de crescer com sacarose ou xilose como única fonte de carbono; 3) verificar que $Y$. lipolytica cresce com velocidade específica de crescimento máxima ( Máx) de $0,49 \mathrm{~h}^{-1}$ num meio complexo contendo glicose, extrato de levedura e peptona (meio YPD), $0,31 \mathrm{~h}^{-1}$ em meio definido com glicose como única fonte de carbono e $0,35 \mathrm{~h}^{-1}$ no mesmo meio, mas com glicerol como única fonte de carbono, sem excreção de metabólitos para o meio de cultivo; 4) verificar que ocorreu limitação por oxigênio nos cultivos em frasco agitado, sendo este o motivo pelo qual as células deixaram de crescer exponencialmente; 5) verificar que o uso de ureia, em vez de sulfato de amônio, como fonte de nitrogênio, contribui para uma variação menor do $\mathrm{pH}$ durante os cultivos, sem prejuízo ao crescimento da levedura; 6) observar que, ao se restringir a oferta de nitrogênio à levedura (aumento da relação $\mathrm{C} / \mathrm{N}$ inicial no meio de 12,6 para 126), as células têm sua morfologia alterada e apresentam maior quantidade de partículas lipídicas; 7) determinar uma composição elementar para a biomassa de $Y$. lipolytica $\left(\mathrm{CH}_{1,98} \mathrm{O}_{0,58} \mathrm{~N}_{0,13}\right)$, em que os átomos de carbono encontram-se em média mais reduzidos do que na biomassa de leveduras como Saccharomyces cerevisiae e Dekkera bruxellensis. Foram também realizados cultivos em biorreator em batelada $\left(1 \mathrm{~L}\right.$ de volume útil, $28{ }^{\circ} \mathrm{C}$, aerobiose plena e pH controlado em 5,0 ), durante os quais foi possível: a) estabelecer um protocolo de 
cultivo para Y. lipolytica em biorreator (que envolvem agitação mecânica, aeração e uso de anti-espumante, entre outras diferenças em relação aos cultivos em frasco); b) confirmar os valores dos principais parâmetros fisiológicos apresentados por esta levedura, anteriormente obtidos a partir de cultivos em frasco; c) confirmar que o fator de conversão de substrato a células $(\mathrm{Y} / \mathrm{s})$ é maior para cultivos realizados com glicerol como fonte única de carbono $(0,53 \mathrm{~g} / \mathrm{g}$ para a linhagem IMUFRJ 50682), do que com glicose $(0,48 \mathrm{~g} / \mathrm{g}$ para a mesma linhagem). Finalmente, cultivos realizados em quimiostato com glicerol como fonte de carbono e energia, limitados por amônio (fonte de nitrogênio, relação $\mathrm{C} / \mathrm{N} 126$ ), às vazões específicas de $0,25 \mathrm{~h}^{-1}$ e $0,15 \mathrm{~h}^{-1}$, permitiram observar que o número de partículas lipídicas por célula de $Y$. lipolytica permaneceu em torno de 2 em ambas as situações e houve uma diminuição no teor de nitrogênio nas células quando a velocidade específica de crescimento diminuiu de 0,25 para $0,15 \mathrm{~h}^{-1}$.

Palavras chave: Yarrowia lipolytica, fisiologia microbiana, leveduras oleaginosas. 


\begin{abstract}
\end{abstract}
The yeast Yarrowia lipolytica has been intensively investigated, especially for being an oleaginous microorganism, thus possessing the capacity of accumulating high amounts of lipids, which mainly takes place in organeles known as lipid bodies. These lipids present several potential biotechnological appications, as in the production of single cell oil or biodiesel. During this research project, we aimed at investigating the physiology of two Y. lipolytica strains: w29, traditionally investigated by the international scientific community, and IMUFRJ 50682, isolated from the Guanabara Bay in Rio de Janeiro. Shake-flask cultivations in baffled Erlenmeyer flasks (total volume $500 \mathrm{~mL}$, liquid volume $100 \mathrm{~mL}, 28{ }^{\circ} \mathrm{C}$ and 200 rotations per minute) with cotton stoppers were carried out and allowed us to: 1) choose a fully defined cultivation medium, in which tiamine is the sole growth factor, suitable for quantitative physiological studies with this yeast; 2) verify that $Y$. lipolytica is not capable of growing on sucrose or xylose as the sole carbon source; 3) observe that $Y$. lipolytica grows with a maximum specific growth rate ( MAX) of $0.49 \mathrm{~h}^{-1}$ in a complex medium containing glucose, yeast extract and peptone (YPD medium), 0.31 $\mathrm{h}^{-1}$ in a defined medium with glucose as the sole carbon source, and $0.35 \mathrm{~h}^{-1}$ in the same medium, but with glycerol as the sole $\mathrm{C}$-source, without excreting metabolites to the cultivation medium; 4) verify that oxygen limitation took place during our shakeflask cultivations and that this caused cells to leave the exponential growth phase; 5) verify that urea can substitute ammonium as the sole nitrogen-source for $Y$. lipolytica, keeping $\mathrm{pH}$ variations less pronounced, without compromising cell growth; 6) observe that cells presented an altered morphology and higher amounts of lipid bodies, when less nitrogen was added to the medium ( $\mathrm{C} / \mathrm{N}$ ratio increased from 12.6 to 126$)$; 7) determine an elemental composition for the biomass of $Y$. lipolytica $\left(\mathrm{CH}_{1,98} \mathrm{O}_{0,58} \mathrm{~N}_{0,13}\right)$, in which the average carbon atom was more reduced with respect to the biomass of yeasts such as Dekkera bruxellensis and Saccharomyces cerevisiae. Bioreactor cultivations in batch mode (working volume $1 \mathrm{~L}, 28{ }^{\circ} \mathrm{C}$, full aerobiosis and $\mathrm{pH}$ controlled at 5.0) were also carried out, which allowed us to: a) define a protocol for the cultivation of $Y$. lipolytica in this system (which involves mechanical agitation, aeration and the use of anti-foam, among other differences with respect to shake-flask cultivations); b) confirm the main physiological parameters presented by this yeast, previously obtained from shake-flask cultivations; c) confirm 
that the biomass yield on substrate $(\mathrm{Yx} / \mathrm{s})$ is higher on glycerol than on glucose $(0.53$ $\mathrm{g} / \mathrm{g}$ and $0.48 \mathrm{~g} / \mathrm{g}$, respectively). Finally, N-limited chemostat cultivations with glycerol as the carbon and energy source and ammonium as the $\mathrm{N}$-source were also performed (dilution rates of $0.25 \mathrm{~h}^{-1}$ and $0.15 \mathrm{~h}^{-1}, \mathrm{C} / \mathrm{N}$ ratio in the medium of 126), allowing us to verify that the number of lipid particles per cell is around 2 under both conditions and that there was a decrease in the $\mathrm{N}$ content in the cells when the specific growth rate decreased from 0.25 to $0.15 \mathrm{~h}^{-1}$.

Key words: Yarrowia lipolytica, microbial physiology, oleaginous yeasts. 


\section{LISTA DE ILUSTRAÇÕES}

Figura 1 - Via de biossíntese de ácidos graxos e triacilgliceróis e degradação de ácidos graxos em leveduras (adaptado de Wang et al., 2013).

Figura 2 - Representação esquemática do metabolismo dos ácidos graxos (adaptado de Tehlivets et al., 2007).

Figura 3 - Síntese de lipídios neutros. O glicerol 3-P usado na síntese de TAG é formado através da redução de dihidroxiacetona fosfato (DHAP), obtida a partir da glicose ou do glicerol. $O$ acetil-CoA citosólico é obtido através da clivagem do citrato pela ATP-citrato-liase (ACL1 e ACL2). Então acetil-CoA é convertido em malonil-CoA através da acil carboxilase (ACC1) e a cadeia de ácidos graxos cresce através da adição de acetilCoA a uma unidade de malonil-CoA seguida da incorporação de mais moléculas de malonil-CoA (Ciclo de alongamento), obtendo assim o AcilCoA. Na síntese de TAG três grupos acila são adicionados ao Glicerol-3$P$, onde primeiramente ocorre a acilação do Glicerol-3-P na posição sn-1 para gerar acil glicerol-3-fosfato (ácido lisofosfatídico; LPA), posteriormente LPA sofre mais uma acilação na posição sn-2 pela ácido lisofosfatídico aciltransferase (SLC1) para gerar ácido fosfatídico (PA). O PA é desfosforilado pela enzima ácido fosfohidrolase fosfatídica (PAP), obtendo diacilglicerol (DAG). Para a síntese final de TAG, DAG é acilada na posição sn-3, através de uma acil-CoA-dependente ou de acil-CoAindependente reação. $\mathrm{Na}$ via de acil-CoA independente, este terceiro grupo acila é fornecido por um glicerofosfolipídio, enquanto que, na via acil- CoA dependente é fornecido pela acil-CoA. A reação de acil-CoAdependente é catalisada por três enzimas: Dga1p, Are1p e Are2p. A formação de esteres de esterol (EE) envolve a reação de uma molécula de ácido graxo (Acil-CoA) com um grupo hidroxila de esteróis, essa reação é catalisada pelas enzimas ARE1 e ARE2 (Adaptado de Seip, et al., 2013). .33

Figura 4 - Papel do RE e PLs nas vias de biossíntese de (a) de éster de esterol e (b) a biossíntese de triacilglicerol em levedura. (A) Vias de biossíntese de éster de esterol. As formas mais comuns de éster de esterol em leveduras são ésteres de ergosterol. A primeira série de enzimas responsáveis pela conversão do colesterol em zimosterol está localizada na membrana do RE. No entanto, o passo de zimosterol para fecosterol é catalisado pela enzima esterol 24 -metil transferase, que é ausente no $\mathrm{RE}$, mas foi mostrado ser uma das principais proteínas de PLs em leveduras. A conversão subsequente do fecosterol de ergosterol e a reação de esterificação final são mediadas por enzimas ligadas ao RE. Por conseguinte, a síntese de ésteres de ergosterol na levedura parece envolver um vai e vem de intermediários altamente hidrofóbicos entre o $\mathrm{RE}$ e as PLs. É possível que isto ocorra através de moléculas lipídicas solúveis, outra sugestão mais realista é uma continuidade física entre as duas organelas durante a biossíntese de éster de esterol. (B) Vias de biossíntese de triacilglicerol. A primeira aciltransferase, Gat1p, pode 
acilar (G3P) ou (DHAP) e é encontrada tanto em PLs quanto na membrana do RE, mas é muito mais abundante na primeira. Há também duas outras aciltransferases exclusivamente localizadas no RE, G3P-AT e DHAP-AT, que são específicas para ambos G3P ou DHAP, respectivamente. O 1-acil-DHAP é então convertido de 1-acil-G3P por uma redutase, Ayr1p, que está localizada predominantemente nas PLs e, em menor grau, no RE. O RE também contém uma extra e distinta atividade de redutase 1-acil-DHAP em adição além da que compartilha com PLs. A segunda aciltransferase, Slc1p ou 1-acil G3P-AT (LPA-AT), é também encontrada nas duas organelas, mas, tal como com ambos Gat1p e Ayr1p, a atividade Slc1p é muito mais abundante nas PLs e o RE tem outra 1-acil G3P-AT que não está presente nas PLs. A desfosforilação de PA para produzir (DAG) é realizada pela PA fosfatase. Esta atividade é altamente regulada na maioria dos organismos, uma vez que está envolvida em vias lipídicas secundárias e na formação de vesículas. Assim como a formação de ésteres de esterol, a biossíntese de TAG em levedura envolve o bidirecional vai e vem de intermediários entre o RE e as PLs (Adaptado de Murphy, 2001).

Figura 5 - Descrição geral da via de degradação de lipídios não polares. O acido graxo livre é oxidado a acil-CoA e pode então ser degradado na via da $\beta$-oxidação, no peroxissoma, que envolve acil-CoA oxidase (POX), a enzima multifuncional (MFE1) e a 3-cetoacil-CoA-tiolase (THIO1). (Adaptado de Ferreira, 2009).

Figura 6 - Partículas lipídicas (PLs) são heterogêneas em tamanho. (a) Múltiplas PLs pequenas. A maioria das células sintetiza múltiplas PLs pequenas para acomodar mais lipídios neutros. Fatores como seipin e fosfatidilcolina podem ajudar a manter PLs pequenas. (b) Gigantes/Super PLs. Adipócitos brancos ou células cultivadas em condições "extremas" (por exemplo, períodos prolongados em ácido oleico), ou determinadas células mutantes (por exemplo, células em que faltam seipin ou CTP: fosfocolina citidil transferase) podem sintetizar Gigantes/Super PLs. Os fatores que podem promover a formação de células Gigantes/Super PLs incluem FITM1/2, Fsp27/Cidea, perilipin1 e ácido fosfatídico (Adaptado de Yang, et al., 2012) 38

Figura 7 - O crescimento de partículas lipídicas (PL). (a) PLs podem crescer por meio da aquisição de lipídios através da entrega direcionada e síntese local. (i) $\mathrm{A}$ entrega de lipídio direcionada: Entrega direcionada/particionada de lipídios neutros, por exemplo, triacilgliceróis (TAG) em PLs na junção PL-RE e dentro da bicamada membranar do RE. FITM1/2 pode facilitar a entrega e/ou particionar o TAG. (ii) A síntese local de lipídios: triacilgliceróis (TAG) e CDP-colina, precursores da síntese de fosfatidil colina (PC), são sintetizados diretamente nas PLs. Enzimas chave envolvidas na síntese de PC (CCT, CTP: fosfocolina citidil transferase), e na síntese de TAG (DGAT2, diacilglicerol O-aciltransferase 2) estão presentes na superfície de PL. DAG: diacilglicerol; CPT: CDP-choline:1, 2 diacilglicerol fosfotransferase; colina-P: fosfocolina. (b) PLs podem crescer através da fusão com PLs 
existentes. (i) PLs podem crescer através da Fsp27 mediando à troca/fusão atípica. Lipídios neutros, por exemplo, triacilgliceróis (TAG), podem trocar livremente através dos sítios de contato das PLs enriquecidas com Fsp27, mas o direcionamento global dos lipídios neutros, isto é, de pequenas para grandes PLs, é impulsionado pela maior pressão no interior da menor PL para outra PL. O mediador Fsp27 de transferência lipídica/fusão atípica leva horas para se completar, e parece ser um modo essencial de crescimento de PL em adipócitos. (ii) PLs podem crescer através da rápida fusão homotípica de PL em adipócitos, e também em alguns mutantes, por exemplo, células deficientes em seipin ou em fosfatidil colina (PC). As alterações específicas na composição de fosfolipídios da superfície da PL, por exemplo, um aumento do ácido fosfatídico (PA) e/ou uma diminuição de fosfatidil colina (PC), podem facilitar a junção das partículas lipídicas. Fatores proteicos que medeiam este tipo de PL fusão permanecem desconhecidos (Adaptado de Yang, et al., 2012).

Figura 8 - Configuração geral do sistema de biorreatores empregado nos cultivos contínuos. 1) Frasco contendo meio de alimentação; 2) Biorreator de bancada; 3) Frasco para coleta do efluente; 4) Bomba peristáltica de alimentação de meio; 5) Bomba peristáltica de retirada de efluente (meio e células); 6) Sistema de agitação; 7) Sistema de medida da vazão de alimentação. Fonte: Basso, T. O. (2011)............................................58

Figura 9 - Fluxograma dos experimentos realizados durante o mestrado. 65

Figura 10 - Logaritmo natural da absorbância a $600 \mathrm{~nm}$ em função do tempo para cultivos com a linhagem Y. lipolytica w29 em diferentes meios de cultura, realizados a $28{ }^{\circ} \mathrm{C}$, agitação de $250 \mathrm{rpm}$ e com fonte de carbono glicose (20 g/L iniciais). As composições dos meios encontram-se descritas na Tabela 1 . 67

Figura 11 - Cálculo da conversão de glicerol a piruvato em Yarrowia lipolytica......72

Figura 12 - Cinética em frasco com a fonte de carbono glicose. Logaritmo natural da absorbância a $600 \mathrm{~nm}$, pH e concentração de glicose em função do tempo para cultivos realizados a $28{ }^{\circ} \mathrm{C}$, agitação de $250 \mathrm{rpm}$ com fonte de carbono glicose (20 g/L iniciais) e fonte de nitrogênio sulfato de amônio (3 g/L iniciais), com a relação $\mathrm{C} / \mathrm{N}(\mathrm{g} / \mathrm{g})$ igual a 12,6. A) Linhagem $Y$. lipolytica IMUFRJ 50682, a e b são duplicatas em meio definido BARTH; B) Linhagem Y. lipolytica w29. Onde a e b são duplicatas em meio definido BARTH e c cultivo em meio YPD. As linhas verticais indicam as mudanças das fases de crescimento observadas..74

Figura 13 - Cinética em frasco com a fonte de carbono glicerol. Logaritmo natural da absorbância a $600 \mathrm{~nm}$, pH e concentração de glicerol em função do tempo para cultivos realizados a $28{ }^{\circ} \mathrm{C}$, agitação de $250 \mathrm{rpm}$ com fonte de carbono glicerol $(20,44 \mathrm{~g} / \mathrm{L}$ iniciais) e fonte de nitrogênio sulfato de amônio (3 g/L iniciais), com a relação C/N (g/g) igual a 12,6. a) Linhagem IMUFRJ 50682, a e b são duplicatas em meio definido BARTH e c é o cultivo em meio YPG; b) Linhagem Y. lipolytica w29, onde a e b são 
duplicatas em meio definido BARTH e c é o cultivo em meio YPG. Em ambos os cultivos utilizou-se $0,15 \mathrm{~mL} / \mathrm{L}$ de anti espumante, conforme detalhado em Materiais e Métodos. As linhas verticais indicam as mudanças das fases de crescimento observadas.

Figura 14 - Cultivos realizados com a linhagem Y. lipolytica IMUFRJ 50682 com as fontes de nitrogênio uréia $(1,1 \mathrm{~g} / \mathrm{L}$ iniciais e $\mathrm{pH} 6,8)$ e sulfato de amônio (3 g/L iniciais e pH 6), em meio BARTH, a $28{ }^{\circ} \mathrm{C}$, agitação de $250 \mathrm{rpm}$ e glicose (20 g/L iniciais) como fonte de carbono. Logaritmo natural da absorbância a $600 \mathrm{~nm}$, concentração de glicose e pH. Em ambos os cultivos manteve-se a relação $\mathrm{C} / \mathrm{N}(\mathrm{g} / \mathrm{g})$ inicial igual a 12,6 . 83

Figura 15 - Cinética de crescimento com restrição da fonte de nitrogênio. Logaritmo natural da absorbância a $600 \mathrm{~nm}$, concentração de glicose e pH em função do tempo para cultivos realizados com as linhagens $Y$. lipolytica IMU̧FRJ 50682 e w29 a $28{ }^{\circ} \mathrm{C}$, agitação de $250 \mathrm{rpm}$ com fonte de carbono glicose $(20 \mathrm{~g} / \mathrm{L}$ iniciais) e fonte de nitrogênio sulfato de amônio (0,3 g/L iniciais). Relação C/N igual a 126. 84

Figura 16 - Imagem de microscopia com aumento de 100 vezes e coloração das PLs com BODIPY 493/503. A) Y. lipolytica w29 na forma leveduriforme, amostra retirada no instante da inoculação; B) $Y$. lipolytica w29 na forma de hifas e aumento das PLs devido à limitação de nitrogênio, amostra retirada no final do cultivo. (Imagens igualmente ampliadas para melhor visualização) 86

Figura 17 - Células de $S$. cerevisiae BY4741 em 4h de cultivo em meio YPD, fixadas com formaldeído. A imagem esquerda sem fluorescência e a direita com fluorescência. 88

Figura 18 - Yarrowia lipolytica IMUFRJ 50682 cultivada em meio YPD por 4h e fixada em formaldeído, imagem esquerda sem fluorescência e imagem direita com fluorescência.

Figura 19 - A) Yarrowia lipolytica IMUFRJ 50682 cultivada em meio YNB por 24h e fixada com formaldeído, B) Yarrowia lipolytica IMUFRJ 50682 cultivada em meio YNB por 24h sem fixação.

Figura 20 - Análise de fluorimetria. Utilizando o corante BODIPY 493/503, dos cultivos em frasco com a levedura $S$. cerevisiae BY4741 em meio YPD e da levedura Yarrowia lipolytica IMUFRJ 50682 em meio YPD e YNB, todos os cultivos com glicose $(20 \mathrm{~g} / \mathrm{L})$ como fonte de carbono, $28{ }^{\circ} \mathrm{C}$ e 250 rpm. A) Primeira análise de fluorimetria e B) Repetição da análise de fluorimetria.

Figura 21 - Logaritmo natural da absorbância a $600 \mathrm{~nm}$ e concentração de glicose durante cultivo em batelada com a linhagem IMUFRJ 50682 em biorreator de $1 \mathrm{~L}, \mathbf{1 0} \mathbf{~ g} / \mathrm{L}$ iniciais de glicose iniciais, $28{ }^{\circ} \mathrm{C}, \mathrm{pH} 5$, agitação $1000 \mathrm{rpm}, 0,3 \mathrm{~mL} / \mathrm{L}$ de antiespumante e ar comprimido a $1 \mathrm{vvm}$. Relação $\mathrm{C} / \mathrm{N}(\mathrm{g} / \mathrm{g})$ inicial igual a 6,25. 
Figura 22 - Logaritmo natural da absorbância a $600 \mathrm{~nm}$ e concentração de glicose durante cultivo em batelada com a linhagem w29 em biorreator de $1 \mathrm{~L}, 5$ $\mathrm{g} / \mathrm{L}$ iniciais de glicose iniciais, $28^{\circ} \mathrm{C}, \mathrm{pH} 5$, agitação $1000 \mathrm{rpm}, 0,3 \mathrm{~mL} / \mathrm{L}$ de antiespumante e ar comprimido a $1 \mathrm{vvm}$. Relação $\mathrm{C} / \mathrm{N}(\mathrm{g} / \mathrm{g})$ inicial igual a 3,13. São apresentados dados de uma duplicata experimental (A e B). .96

Figura 23 - Logaritmo natural da absorbância a 600 nm e concentração de glicerol durante cultivo em batelada em biorreator de $1 \mathrm{~L}$ com as linhagens IMUFRJ 50682 e w29, a $28^{\circ} \mathrm{C}$, pH 5, agitação $1000 \mathrm{rpm}, 0,3 \mathrm{~mL} / \mathrm{L}$ de antiespumante, ar comprimido a $1 \mathrm{vvm}$ e $5 \mathrm{~g} / \mathrm{L}$ iniciais de glicerol como fonte de carbono. Relação C/N (g/g) inicial igual a 3,13.

Figura 24 - Frações molares de $\mathrm{O}_{2}$ e $\mathrm{CO}_{2}$ no gás de saída do biorreator e concentração de oxigênio dissolvido (DO) durante os cultivos contínuos realizados neste trabalho. São apresentados os dados de uma duplicata experimental (à exceção da variável fração molar de $\mathrm{O}_{2}$, para a qual somente há uma medida, dados em azul). Cultivos realizados com a linhagem $Y$. lipolytica IMUFRJ 50682, sob limitação da fonte de nitrogênio. Reator de $1 \mathrm{~L}, 28{ }^{\circ} \mathrm{C}, \mathrm{pH} 5,0$, agitação $1000 \mathrm{rpm}, 0,3 \mathrm{~mL} / \mathrm{L}$ de antiespumante, ar comprimido a $0,5 \mathrm{vvm}$, alimentação com $20 \mathrm{~g} / \mathrm{L}$ de glicerol como fonte de carbono e $0,3 \mathrm{~g} / \mathrm{L}$ de sulfato de amônio, relação $\mathrm{C} / \mathrm{N}(\mathrm{g} / \mathrm{g})$ igual a 126. Início do cultivo em batelada, seguido por etapas contínuas com vazões específicas de 0,25 e $0,15 \mathrm{~h}^{-1}$ respectivamente. Os instantes em que foram realizadas mudanças na vazão específica estão indicados com setas. 100

Figura 25 - Regressões lineares para obtenção dos fatores de conversão do substrato a biomassa seca na fase exponencial ( $Y X S \exp )$ dos cultivos em frasco, em meio definido BARTH, com a fonte de carbono glicose. Cultivos realizados a $28{ }^{\circ} \mathrm{C}$, agitação de $250 \mathrm{rpm}$ com fonte de carbono glicose $(20 \mathrm{~g} / \mathrm{L}$ iniciais) e fonte de nitrogênio sulfato de amônio (3 g/L iniciais), com a relação $\mathrm{C} / \mathrm{N}(\mathrm{g} / \mathrm{g})$ igual a 12,6. Linhagem IMUFRJ 50682

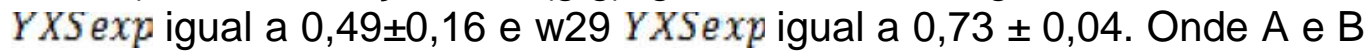
são duplicatas. 120

Figura 26 - Regressões lineares para obtenção dos fatores de conversão do substrato a biomassa seca na fase exponencial ( $Y X$ Sexp) dos cultivos em frasco, em meio definido BARTH, com a fonte de carbono glicerol. Cultivos realizados a $28{ }^{\circ} \mathrm{C}$, agitação de $250 \mathrm{rpm}$ com fonte de carbono glicerol (21 g/L iniciais) e fonte de nitrogênio sulfato de amônio (3 g/L iniciais), com a relação $\mathrm{C} / \mathrm{N}(\mathrm{g} / \mathrm{g})$ igual a 12,6. Linhagem IMUFRJ 50682 $Y X S \exp$ igual a 0,58 $\pm 0,02$ e w29 YXSexp igual a 0,71 $\pm 0,04$. Onde A e B são duplicatas. 121

Figura 27 - Regressões lineares para obtenção dos fatores de conversão do substrato a biomassa seca na fase exponencial ( $Y X$ Sexp) dos cultivos em biorreator, em meio definido BARTH, com a fonte de carbono glicerol. Cultivo em batelada em biorreator de $1 \mathrm{~L}$, a $28{ }^{\circ} \mathrm{C}, \mathrm{pH} 5$, agitação $1000 \mathrm{rpm}, 0,3 \mathrm{~mL} / \mathrm{L}$ de antiespumante, ar comprimido a $1 \mathrm{vvm}$ e $5 \mathrm{~g} / \mathrm{L}$ iniciais de glicerol como fonte de carbono. Relação C/N $(\mathrm{g} / \mathrm{g})$ inicial 
igual a 3. Linhagem IMUFRJ 50682 YXSexp igual a 0,55 e w29 YXSexp igual a 0,59 .

Figura 28 - Regressões lineares para obtenção dos fatores de conversão do substrato a biomassa seca na fase exponencial $(Y X S \exp )$ dos cultivos em biorreator, em meio definido BARTH, com a fonte de carbono glicose. Cultivo em batelada em biorreator de $1 \mathrm{~L}$, a $28{ }^{\circ} \mathrm{C}, \mathrm{pH} 5$, agitação $1000 \mathrm{rpm}, 0,3 \mathrm{~mL} / \mathrm{L}$ de antiespumante, ar comprimido a $1 \mathrm{vvm}$ e $5 \mathrm{~g} / \mathrm{L}$ iniciais de glicose como fonte de carbono. Relação $\mathrm{C} / \mathrm{N}(\mathrm{g} / \mathrm{g})$ inicial

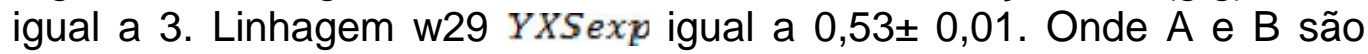
duplicatas. 122

Figura 29 - Regressões lineares para obtenção dos fatores de conversão do substrato a biomassa seca na fase exponencial $(Y X S \exp )$ dos cultivos em biorreator, em meio definido BARTH, com a fonte de carbono glicose. Cultivo em batelada em biorreator de $1 \mathrm{~L}$, a $28{ }^{\circ} \mathrm{C}, \mathrm{pH} 5$, agitação $1000 \mathrm{rpm}, 0,3 \mathrm{~mL} / \mathrm{L}$ de antiespumante, ar comprimido a $1 \mathrm{vvm}$ e $10 \mathrm{~g} / \mathrm{L}$ iniciais de glicose como fonte de carbono. Relação $\mathrm{C} / \mathrm{N}(\mathrm{g} / \mathrm{g})$ inicial igual a 6,25. Linhagem IMUFRJ 50682 YXS exp igual a 0,48.....122

Figura 30 - Cromatograma de uma amostra no instante inicial de um cultivo com a fonte de carbono glicose.

Figura 31- Cromatograma de uma amostra no instante final de um cultivo com a fonte de carbono glicose, mostrando a glicose esgotada e nenhum outro metabólito produzido. 123 


\section{LISTA DE TABELAS}

Tabela 1 - Composição dos meios de cultura definidos empregados neste trabalho*. 50

Tabela 2 - Meio descrito por Barth e Gaillardin (1996) e composição do meio usado neste trabalho, a partir de modificações do anterior.

Tabela 3 - Velocidades específicas máximas de crescimento da levedura $Y$. lipolytica w29, durante o crescimento em diferentes meios de cultura, em incubador rotativo

Tabela 4 - Velocidades específicas máximas de crescimento e fatores de conversão de substrato a células de diferentes linhagens de $Y$. lipolytica..

Tabela 5 - Comparação entre os cultivos com restrição da fonte de nitrogênio (relação $\mathrm{C} / \mathrm{N}$ inicial 126) e sem restrição da fonte de nitrogênio (relação $\mathrm{C} / \mathrm{N}$ inicial 12,6).

Tabela 6 - Velocidades específicas máximas das linhagens de levedura empregadas nos estudos de obtenção de imagens de partículas lipídicas

Tabela 7 - Quantificação de partículas lipídicas por análise de imagem nas leveduras S. cerevisiae BY4741 e Yarrowia lipolytica IMUFRJ 50682.....90

Tabela 8 - Composição elementar da biomassa da levedura Y. lipolytica w29 .94

Tabela 9 - Parâmetros fisiológicos obtidos nos cultivos em biorreator, em modo batelada, para Y. lipolytica IMUFRJ 50682 e w29.

Tabela 10 - Parâmetros fisiológicos calculados a partir do cultivo em quimiostato em diferentes vazões de alimentação. 101

Tabela 11 - Análise das partículas lipídicas nos diferentes estados estacionários do cultivo em quimiostato. 104

Tabela 12 - Análise elementar da biomassa celular dos cultivos em quimostato em diferentes velocidades específicas de crescimento 105 


\section{LISTA DE ABREVIATURAS, SIGLAS E SÍMBOLOS}

\begin{tabular}{|c|c|}
\hline AA & Ácido araquidônico \\
\hline $\operatorname{ABS}(600)$ & Absorbância no comprimento de onda de 600 nm \\
\hline$A C$ & Ácido cítrico \\
\hline ACC & Acil carboxilase \\
\hline $\mathrm{ACL}$ & ATP-citrato-liase \\
\hline AOX & Acil-CoA oxidase \\
\hline$A R E 1$ & Gene que codifica a enzima Acil-CoA:esterol aciltransferase \\
\hline ARE2 & Gene que codifica a enzima Acil-CoA:esterol aciltransferase \\
\hline Are1p & Enzima envolvida na síntese de triacilgliceróis \\
\hline Are2p & Enzima envolvida na síntese de triacilgliceróis \\
\hline Ayr1p & Enzima redutase \\
\hline CCT ou CTP & Fosfocolina citidil transferase \\
\hline Ciclo TCA & Ciclo do ácido cítrico \\
\hline $\mathrm{C} / \mathrm{N}$ & Relação entre a concentração de carbono e nitrogênio no meio de cultura \\
\hline CPT - CDP-choline & 1,2 Diacilglicerol colina fosfotransferase \\
\hline DAG & Diacilglicerol \\
\hline DEQ & Departamento de Engenharia Química \\
\hline Dga1p & Enzima envolvida na síntese de triacilgliceróis \\
\hline DGAT2 & Diacilglicerol O-aciltransferase 2 \\
\hline DHA & Ácido docosahexanóico \\
\hline DHAP - & Dihidroxiacetona fosfato \\
\hline DHAP-AT & Aciltransferase exclusivamente localizada no RE \\
\hline EE & Ésteres de esterol \\
\hline EM & Enzima málica \\
\hline EPA & Ômega-3 ácido eicosapentaenoico \\
\hline EPUSP & Escola Politécnica da Universidade de São Paulo \\
\hline FITM1/2 & FITM1 e FITM2 indutores de armazenamento de gordura transmembranar \\
\hline Fsp27 & Proteína graxo específica de 27 kDa \\
\hline G3P- & Aciltransferase exclusivamente localizada no RE \\
\hline$D$ & Vazão específica de alimentação $\left(\mathrm{h}^{-1}\right)$ \\
\hline DW & Massa seca de células (“dry weight”) \\
\hline G-3-P & Glicerol-3-fosfato \\
\hline GEnBio & Grupo de Engenharia de Bioprocessos \\
\hline Gat1p & Enzima aciltransferase \\
\hline GS & Glutamina sintetase \\
\hline ICA & Ácido isocítrico \\
\hline Ks & Constante de saturação ou de Monod \\
\hline LPA & Ácido lisofosfatídico \\
\hline
\end{tabular}




\begin{tabular}{|c|c|}
\hline LPA-AT & Aciltransferase codificada pelo gene S/c1p \\
\hline LRO1 & Enzima fosfolípidio: diacilglicerol aciltransferase \\
\hline$K_{\mathrm{m}}$ & Constante de Michaellis-Menten ou constante de saturação pelo substrato \\
\hline MFE1 & Enzima multifuncional de beta oxidação \\
\hline $\mathrm{m}_{\mathrm{s}}$ & Taxa de manutenção celular [(g glycerol).(g DW.h $\left.)^{-1}\right]$ \\
\hline NAD-GDH & Enzima glutamato desidrogenase NAD-dependente \\
\hline NADPH-GDH & Enzima glutamato desidrogenase NADPH-dependente \\
\hline PA & Ácido fosfatídico \\
\hline PAP & Enzima ácido fosfohidrolase fosfatídica \\
\hline PC & Fosfatidilcolina \\
\hline PL & Partícula lipídica \\
\hline pO2 & Disponibilidade de oxigênio dissolvido \\
\hline POX & Enzima acil-CoA oxidase \\
\hline PUFAs & Ácidos graxos poli-insaturados \\
\hline$q_{\mathrm{cO} 2}$ & Velocidade específica de produção de $\mathrm{CO}_{2}\left[\left(\mathrm{~mol} \mathrm{CO}_{2}\right) \cdot(\mathrm{g} \text { DW.h })^{-1}\right]$ \\
\hline qo2 & Taxa específica de consumo de oxigênio $\left[\left(\mathrm{mol} \mathrm{O}_{2}\right) \cdot(\mathrm{g} \mathrm{DW} \cdot \mathrm{h})^{-1}\right]$ \\
\hline $\mathrm{q}_{\mathrm{s}(\mathrm{NH} 4)}$ & Taxa específica de consumo de amônia $\left[\left(\mathrm{mol} \mathrm{NH}_{4}\right) .(\mathrm{g} \mathrm{DW} . \mathrm{h})\right]$ \\
\hline $\mathrm{q}_{\mathrm{s}(\text { glycerol) }}$ & Taxa específica de consumo de glicerol $\left[(\mathrm{mol} \text { glycerol).(g DW.h })^{-1}\right]$ \\
\hline$q_{s}$ & Taxa específica de consumo de energia [mg S /(mg DW.h)] \\
\hline RE & Retículo endoplasmático \\
\hline $\mathrm{RQ}$ & $\begin{array}{l}\text { Coeficiente respiratório, razão entre a taxa de consumo de oxigênio e a taxa } \\
\text { de produção de } \mathrm{CO}_{2}\left(\mathrm{q}_{\mathrm{CO} 2} / \mathrm{q}_{\mathrm{O} 2}\right)\end{array}$ \\
\hline SCO & Single cell oil \\
\hline SLC1 & Ácido lisofosfatídico aciltransferase \\
\hline Slc1p & Aciltransferase \\
\hline $\mathrm{S}_{\text {residual }}$ & Substrato limitante $\left[\mathrm{mg} \mathrm{NH}_{4} \cdot \mathrm{L}^{-1}\right]$ \\
\hline STRES & Elementos responsivos ao estresse ("Stress Responsive Element”) \\
\hline TAG & Triacilgliceróis \\
\hline $\mathrm{T}_{\mathrm{d}}$ & Tempo de duplicação das células \\
\hline THIO1 & 3-cetoacil-CoA-tiolase \\
\hline UFRJ & Universidade Federal do Rio de Janeiro \\
\hline USP & Universidade de São Paulo \\
\hline $\mathrm{V}$ & Volume de liquido no reator [L] \\
\hline$x$ & Concentração celular [g DW. $\mathrm{L}^{-1}$ ] \\
\hline $\mathrm{X}_{\text {FINAL }}$ & Concentração celular final [g DW. $\left.\mathrm{L}^{-1}\right]$ \\
\hline $\mathrm{x}_{\mathrm{CO} 2 \mathrm{e}}$ & Fração molar de dióxido de carbono no gás de entrada \\
\hline $\mathrm{x}_{\mathrm{CO} 2 \mathrm{~s}}$ & Fração molar de dióxido de carbono no gás de saída \\
\hline $\mathrm{x}_{\mathrm{O} 2 \mathrm{e}}$ & Fração molar de oxigênio no gás de entrada \\
\hline $\mathrm{X}_{\mathrm{O} 2 \mathrm{~s}}$ & Fração molar de oxigênio no gás de saída \\
\hline $\mathrm{Y}_{\mathrm{X} / \mathrm{NH} 4}$ & Fator de conversão de amônia a célula $\left[(\mathrm{g} \mathrm{DW}) \cdot\left(\mathrm{g} \mathrm{NH}_{4}\right)^{-1}\right]$ \\
\hline
\end{tabular}




$\begin{array}{ll}Y_{\mathrm{X} / \mathrm{glicerol}} & \text { Fator de conversão de glicerol a célula }\left[(\mathrm{g} D W) .(\mathrm{g} \text { glycerol })^{-1}\right] \\ \mathrm{Y}_{\mathrm{x} / \mathrm{s}}^{\text {true }} & \text { Fator de conversão substrato a célula verdadeiro }[\mathrm{g} \mathrm{DW} / \mathrm{g} \mathrm{S}] \\ \mathrm{gs} & \text { Fluxo molar do gás de saída }[\mathrm{mol} / \mathrm{h}] \\ \mathrm{ge} & \text { Fluxo molar do gás de entrada }[\mathrm{mol} / \mathrm{h}] \\ \mathrm{G}_{0} & \text { Energia livre de Gibbs }\left[\mathrm{kJ} \cdot \mathrm{mol}^{-1}\right] \\ \mu_{\text {Máx }} & \text { Velocidade específica máxima de crescimento }\left[\mathrm{h}^{-1}\right] \\ \mu & \text { Velocidade específica de crescimento }\left[\mathrm{h}^{-1}\right]\end{array}$




\section{SUMÁRIO}

1 INTRODUÇÃO

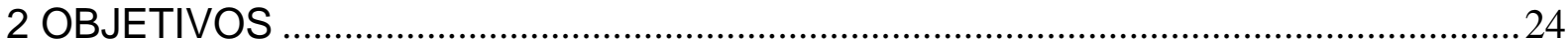

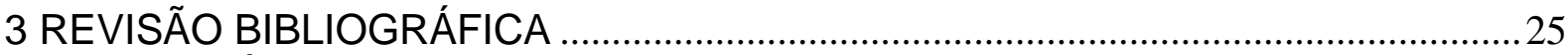

3.1 A ESPÉCIE DE LEVEDURA Yarrowia lipolytica E A LINHAGEM IMUFRJ

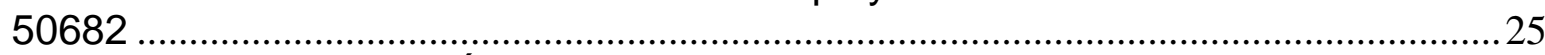

3.2 METABOLISMO LIPÍDICO EM LEVEDURAS ..................................................22

3.2.1 Metabolismo da levedura Y. lipolytica em comparação a S. cerevisiae......27

3.2.2 Metabolismo lipídico........................................................................................29

3.2.2.1 Síntese de lipídios .........................................................................................

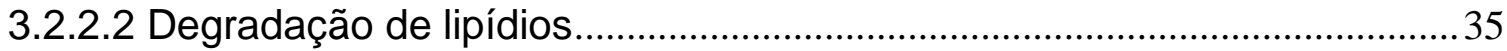

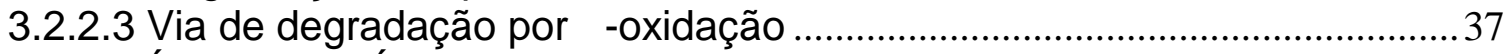

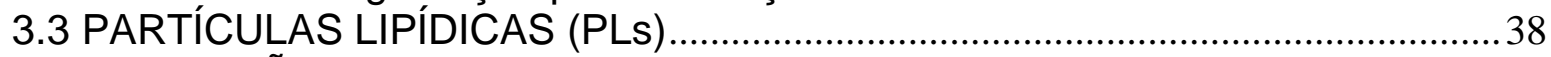

3.4 FORMAÇÃO E CRESCIMENTO DE PLS..............................................................40

3.5 CULTIVOS EM RESTRIÇÃO DE NITROGÊNIO …….........................................4

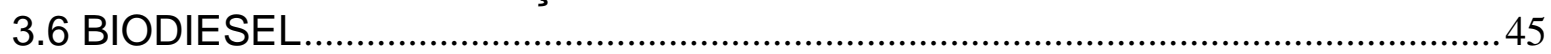

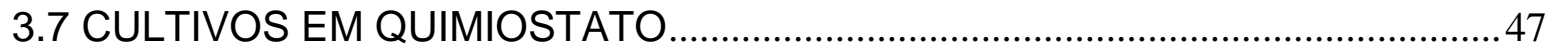

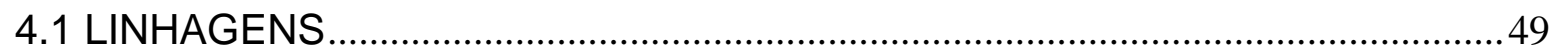

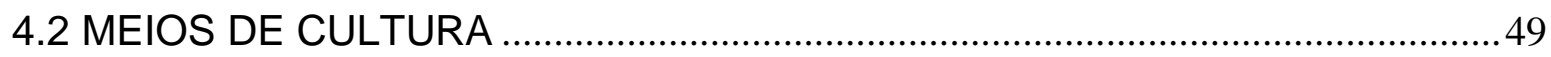

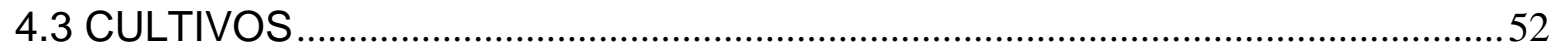

4.3.1. Cultivos de Y. lipolytica em frasco agitado....................................................52

4.3.1.1 Cultivos para avaliação preliminar de meios de cultura ……………….......52

4.3.1.2. Crescimento de $Y$. lipolytica em diferentes fontes de carbono...................53

4.3.1.3 Cinéticas de crescimento de $Y$. lipolytica em glicose e glicerol...................54

4.3.1.4. Cultivos para análise de partículas lipídicas.................................................55

4.3.1.5 Cultivo para análise elementar da biomassa de Y. lipolytica......................56

4.3.2. Cultivos de Y. lipolytica em biorreator .............................................................56

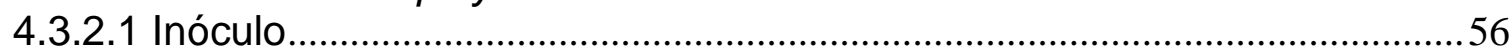

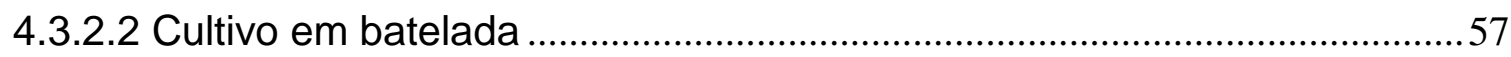

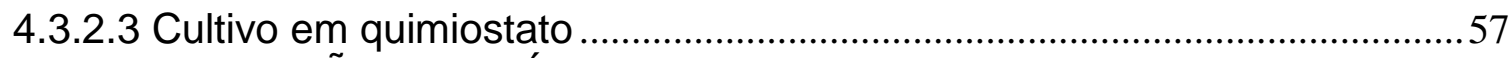

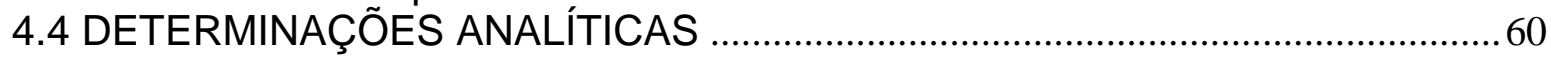

4.4.1 Quantificação da concentração celular..............................................................6

4.4.2 Quantificação da concentração de metabólitos extracelulares........................60

4.4.3 Análise de fluorescência por fluorimetria..........................................................61

4.4.4 Análise de PLs por microscopia de fluorescência...........................................61

4.4.5 Determinação da fração molar de $\mathrm{O}_{2}$ e $\mathrm{CO}_{2}$ no gás de saída do biorreator61

4.4.6 Análise elementar da biomassa de Y. lipolytica ................................................62

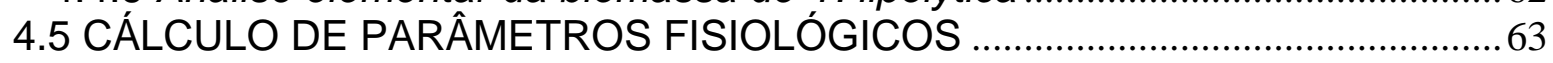

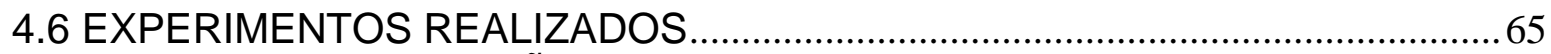

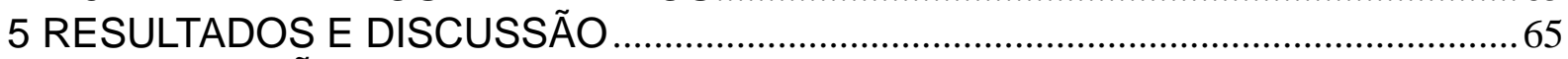

5.1 AVALIAÇÃO DE MEIOS DE CULTURA DEFINIDOS ADEQUADOS AO

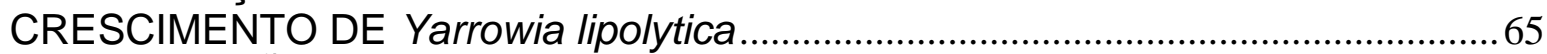

5.2 AVALIAÇÃO DO CRESCIMENTO DA LEVEDURA Yarrowia lipolytica EM DIFERENTES FONTES DE CARBONO ………………………………………......... 70

5.3 CINÉTICAS DE CRESCIMENTO DE Yarrowia lipolytica EM FRASCO

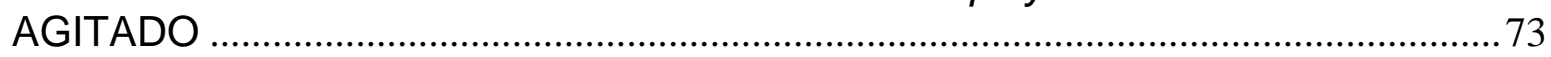

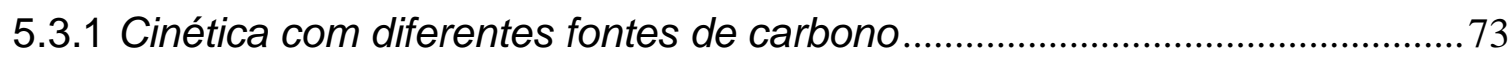

5.3.2 Cinética com diferentes fontes de nitrogênio.................................................... 81

5.3.3 Cinética de crescimento com restrição da fonte de nitrogênio ........................83 


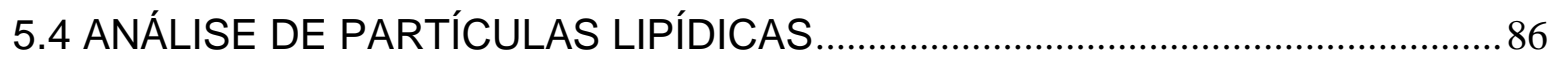

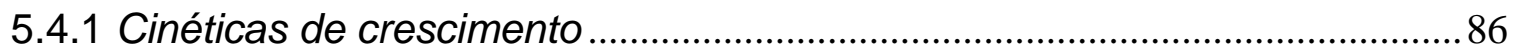

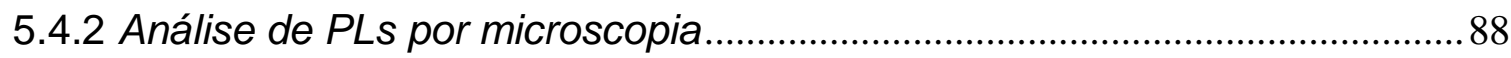

5.4.3 Análise de PLs por fluorimetria ……………………………………….......91

5.5 ANÁLISE ELEMENTAR DA BIOMASSA DE Y. lipolytica ....................................93

5.6 CINÉTICAS DE CRESCIMENTO DE Y. lipolytica EM BIORREATOR ...............95

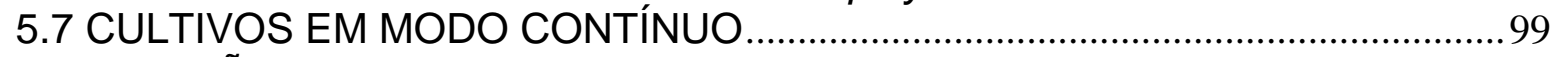

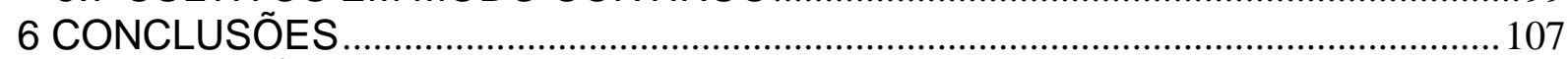

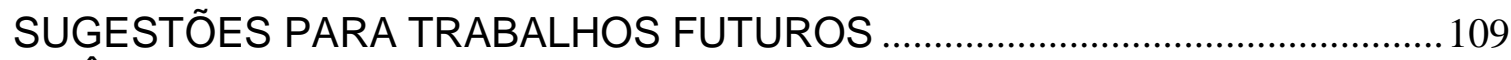

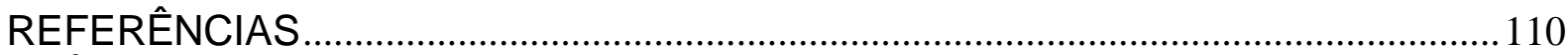

APÊNDICE A - Determinação do fator de conversão substrato a célula dos cultivos

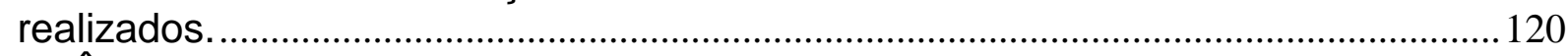

APÊNDICE B - Cromatogramas inicial e final de um cultivo .........................................123 


\section{INTRODUÇÃO}

Este trabalho com a levedura Yarrowia lipolytica representa o início de uma nova linha de pesquisa no Grupo de Engenharia de Bioprocessos (GEnBio) do Departamento de Engenharia Química (DEQ) da Escola Politécnica da Universidade de São Paulo (EPUSP). Trata-se da segunda dissertação de mestrado gerada dentro deste grupo de pesquisa.

O trabalho insere-se numa colaboração em pesquisa com a Universidade Federal do Rio de Janeiro (UFRJ), em projeto financiado pelo CNPq e coordenado pela Profa. Dra. Maria Alice Zarur Coelho, da Escola de Química daquela instituição e envolve a formação de uma rede multidisciplinar de pesquisadores para o estudo da levedura Yarrowia lipolytica IMUFRJ 50682, isolada da Baía da Guanabara (RJ). O projeto como um todo envolveu tanto aspectos básicos desta levedura (como por exemplo, aqueles relacionados à transição entre a morfologia unicelular e a morfologia filamentosa), como aspectos aplicados, principalmente relacionados ao potencial de utilização deste microrganismo em diferentes aplicações industriais, sendo uma delas na obtenção de lipídios para posterior conversão em biodiesel.

Muitos estudos fundamentais sobre as partículas lipídicas e o metabolismo lipídico em geral foram realizados em leveduras. No entanto, a maioria destes estudos foi realizada com a levedura-modelo Saccharomyces cerevisiae, que não é uma levedura oleaginosa e que acumula apenas moderada quantidade de lipídios (menos de $15 \%$ da sua biomassa seca). Em contraste, pouco se conhece do metabolismo e da fisiologia das linhagens de $Y$. lipolytica, uma levedura sabidamente oleaginosa, que pode acumular até $50 \%$ de sua biomassa seca em lipídios (Beopoulos et al., 2009b).

Neste contexto, este trabalho teve por finalidade obter um maior conhecimento sobre a fisiologia, o acúmulo de lipídios e a formação das partículas lipídicas na levedura Yarrowia lipolytica IMUFRJ 50682. Além desta linhagem, também foi estudada a linhagem Yarrowia lipolytica w29, como uma referência, por ser esta uma das linhagens mais estudadas e descritas na literatura científica. Espera-se que os resultados aqui apresentados contribuam para um maior entendimento das leveduras oleaginosas em geral e para o desenvolvimento de aplicações industriais com 


\section{OBJETIVOS}

Este trabalho tem por objetivo estudar a fisiologia e a formação de partículas lipídicas (PLs) em duas linhagens da levedura Y. lipolytica (IMUFRJ 50682 e w29), em meio de cultura definido e em diferentes sistemas de cultivo (frasco agitado e biorreator, nos modos batelada e contínuo) e diferentes condições de cultivo, como o uso de diferentes fontes de carbono e nitrogênio. 


\section{REVISÃO BIBLIOGRÁFICA}

\subsection{A ESPÉCIE DE LEVEDURA Yarrowia lipolytica E A LINHAGEM IMUFRJ 50682}

A levedura Yarrowia lipolytica é um microrganismo estritamente aeróbio, eucariótico, do reino Fungi, pertencente à classe dos Ascomicetos, subclasse Hemiascomicetos. Apresenta dimorfismo, podendo suas células ter a morfologia unicelular característica de leveduras, pseudo-hifas ou hifas septadas, dependendo das condições de cultivo (Barth \& Gaillardin, 1997). É considerada uma levedura não convencional, não patogênica, que desenvolveu mecanismos sofisticados para o uso eficiente de substratos hidrofóbicos como única fonte de carbono, sendo frequentemente encontrada em ambientes ricos nestes substratos, tais como alcanos e/ou lipídios (Athenstaedt et al., 2006; Beopoulos et al., 2009b).

Y. lipolytica pode ser considerada uma levedura oleaginosa, pois possui uma alta capacidade de acumular lipídios em sua biomassa, podendo chegar até cerca de $50 \%$ de seu peso seco (Beopoulos et al., 2009b), sendo capaz também de acumular lipídios mesmo durante o crescimento em açúcares como fonte de carbono. Leveduras oleaginosas acumulam lipídios em níveis superiores a $20 \%$ de sua biomassa seca, no entanto, para que acumulem grandes quantidades, necessitam estar sob a condição de limitação de nutrientes primários no meio, diferentes da fonte de carbono, como por exemplo, a fonte de nitrogênio. Nesta condição, o crescimento celular torna-se inviável e os ésteres de esterol deixam de ser usados na proliferação da membrana, sendo a assimilação da fonte de carbono redirecionada para a síntese de lipídios, como forma de reserva energética. Assim, algumas leveduras oleaginosas podem acumular lipídios em níveis superiores a $70 \%$ de sua biomassa seca (Beopoulos et al., 2009a; Hall e Ratledge,1977; Murphy, 2001).

Os lipídios armazenados pelas leveduras oleaginosas consistem de triacilgliceróis (TAG) e ésteres de esterol (EE), chamados coletivamente de lipídios neutros, e suas proporções podem variar de acordo com a espécie de levedura e também com a fonte de carbono em que são cultivadas. $O$ armazenamento das moléculas lipídicas ocorre em um compartimento da célula conhecido como partícula 
lipídica (PL) ou corpúsculo lipídico, que consiste em um núcleo hidrofóbico envolto por uma camada de fosfolipídios com proteínas incorporadas, ou seja, por uma membrana (Athenstaedt et al., 2006; Beopoulos et al., 2011; Beopoulos et al., 2012).

Yarrowia lipolytica vem sendo extensamente estudada e já foi utilizada em aplicações industriais como na produção de proteína microbiana (single cell protein), de aroma de pêssego, de ácido cítrico (Tsugawa et al., 1969; Sabirova et al., 2011; Nicaud et al., 2002). Xue et al. (2013) conseguiram produzir ômega-3 ácido eicosapentaenoico (EPA) em Yarrowia lipolytica modificada geneticamente. Além disso, essa levedura secreta várias enzimas, como proteases, lipases, esterases e fosfatases, todas de grande interesse biotecnológico (Nicaud et al., 2002). Linhagens do tipo selvagem e geneticamente modificadas podem ser utilizadas para a bioconversão de alcanos e ácidos graxos na produção de aromas, para a produção de single cell oil (SCO), em biorremediação, na química fina, para a biotransformação de esteroides, na produção de proteínas heterólogas e na indústria alimentícia (Fickers et al., 2005).

Atualmente podemos obter microrganismos melhorados através da engenharia genética, por exemplo, para favorecer a produção de óleo, o qual pode ser usado na forma de combustível, parecendo ser este o caminho a seguir para uma terceira geração de biocombustíveis, em que os óleos serão produzidos a partir de materiais mais adequados (tais como glicerol, celulose, ou mesmo o resíduo de óleo), em vez de serem extraídos de matérias-primas que também poderiam servir como fonte de alimentos. A capacidade de Y. lipolytica em produzir moléculas de cadeia longa e de ajustar o seu metabolismo para a produção de óleos específicos pode contribuir para a produção de combustíveis com maior eficiência energética (Beopoulos et al., 2009b). Essa capacidade também pode ser usada na produção de SCOs com alto valor agregado, com quantidades elevadas de ácidos graxos poli-insaturados (PUFAs), tais como o ácido araquidônico (AA) e o docosahexanóico (DHA), que não possuem alternativas de produção através de matéria prima vegetal (Flakas et al., 2009).

A linhagem Y. lipolytica IMUFRJ 50682, estudada neste trabalho, foi isolada de um estuário na Baía da Guanabara no Rio de Janeiro. Inicialmente denominada como $Y$. lipolytica 583, essa levedura faz parte de um grupo de 16 linhagens isoladas de ambientes marinhos no Rio de Janeiro, que foram submetidas à avaliação da capacidade de crescimento em ambientes marinhos e estuários, 
visando o emprego das mesmas na biorremediação de áreas contaminadas por hidrocarbonetos (Hagler e Mendonça-Hagler, 1979).

\subsection{METABOLISMO LIPÍDICO EM LEVEDURAS}

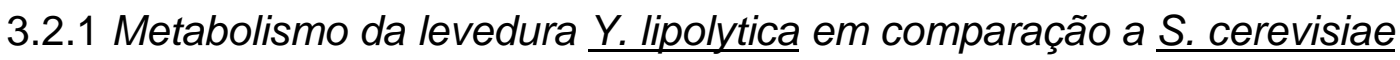

Y. lipolytica é uma levedura estritamente aeróbia. Por conta dessa característica, essa levedura não tem sua taxa de respiração, seu conteúdo de citocromos e as propriedades mitocondriais afetados pela concentração de glicose, sendo também incapaz de produzir etanol (Coelho et al., 2010). Diferentemente, a levedura $S$. cerevisiae, na presença de excesso de glicose, sofre uma mudança metabólica, de metabolismo oxidativo para oxi-redutor e/ou fermentativo, com produção de etanol (Beopoulos et al., 2009b).

S. cerevisiae cataboliza glicose e/ou sacarose eficientemente, gerando pouca quantidade de glicerol e quase nenhum ácido graxo, pois não utiliza ácidos graxos eficientemente para gerar energia, devido a sua capacidade limitada de $\beta$-oxidação. Também não consegue usar uma mistura de TAG e ácidos graxos como fonte de carbono devido à sua incapacidade de secretar lipases. Em contraponto, Y. lipolytica apresenta bom crescimento em ácido oleico e é capaz de degradar várias hexoses, tais como glicose, frutose e manose. No entanto, de maneira geral, a membrana das células não é livremente permeável para uma variedade de solutos, açúcares entre eles. O transporte é o primeiro passo para o metabolismo de carboidratos, exceto nos casos em que o di- ou trissacarídeo é hidrolisado no exterior da célula. Contudo, sacarose não pode ser utilizada por linhagens selvagens de $Y$. lipolytica, devido à ausência da enzima invertase (ou sacarase).

Em condições de limitação de nutrientes (nitrogênio, fosforo, magnésio, etc.) e na presença de carbono em excesso, Y. lipolytica converte o carbono em excesso em lipídios (triacilgliceróis e ésteres de esterol). Quando em limitação de tiamina e nitrogênio, converte o excesso de carbono em intermediários do ciclo TCA, tais como o ácido cítrico (AC), o ácido isocítrico (ICA), o ácido 2-cetoglutárico ou ainda o ácido pirúvico (Beopoulos et al., 2009b; Coelho et al.,2010). 
Uma característica que diferencia leveduras oleaginosas de não oleaginosas é a presença da enzimas ATP citrato liase (ACL) nas primeiras (Holdsworth et al., 1988; Zhang et al., 2007). Muitos autores também consideram que as enzimas acetil-CoA carboxilase (ACC) e a málica são essenciais para a acumulação de lipídios (Waite and Wakil, 1962; Hasslacher et al.,1993; Zhang et al., 2007).

Durante a evolução, Y. lipolytica empregou estratégias elaboradas e mecanismos de adaptação para o uso eficiente dos substratos hidrofóbicos, tais como alcanos, ácidos graxos e os triacilgliceróis. Esta levedura é capaz de produzir um agente emulsionante solúvel em água (composto por $83 \%$ de carboidrato e 17\% de proteína), chamado por Cirigliano e Carman (1985) de Liposan, também modificou sua superfície celular para facilitar a adesão de gotículas hidrofóbicas (saliências de superfície celular), maximizando o contato célula-substrato e desenvolvendo complexos mecanismos de transporte para a entrada destes compostos na célula (Beopoulos et al., 2009b). Um resumo do metabolismo de leveduras com diferentes fontes de carbono pode ser observado na Figura 1, que inclui a via lipogênica (formação de lipídios) e a via glicolítica. 


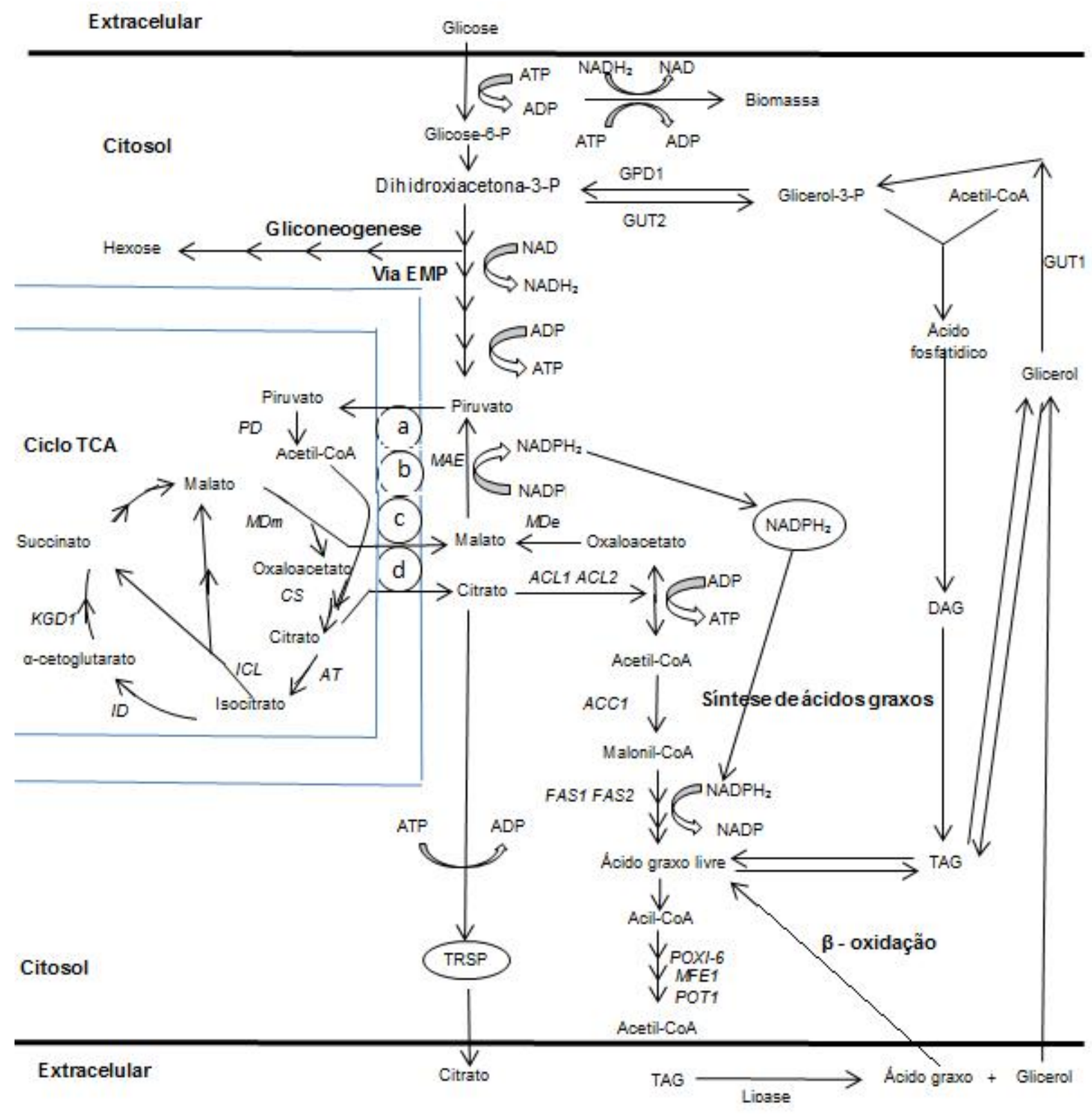

Figura 1 - Via de biossíntese de ácidos graxos e triacilgliceróis e degradação de ácidos graxos em leveduras (adaptado de Wang et al., 2013).

\subsubsection{Metabolismo lipídico}

Ácidos graxos celulares são derivados de três fontes diferentes (Figura 2): fonte externa (que envolve a absorção de ácidos graxos, óleos e triacilgliceróis a partir do meio e a sua acumulação inalterada ou modificada na PL), lipídios endógenos reciclados (proteínas degradadas) e síntese e alongamento de novo (que envolve a produção de ácidos graxos pela via de Kennedy). Os ácidos graxos são compostos essenciais para a célula e caso a levedura não os obtenha do meio de 
cultivo a quantidade necessária para as funções celulares e para o crescimento, é necessário realizar uma síntese endógena (Tehlivets et al., 2007; Beopoulos et al., 2009b).

Uma vez absorvidos ou sintetizados nas células de levedura, os ácidos graxos podem ser degradados pela via de $\beta$-oxidação para conservação de energialivre (por exemplo na forma de ATP) ou serem esterificados e armazenados na forma de lipídios neutros (TAG e EE). TAGs são a forma mais eficiente de acumular ácidos graxos como reserva de energia ou como blocos de construção para a síntese da membrana lipídica, pois o ácido graxo "livre" apresenta propriedades potencialmente nocivas para a célula, como a perturbação da membrana e a formação de proteína-detergentes (Tehlivets et al., 2007).

Com o sequenciamento do genoma de Saccharomyces cerevisiae, abriram-se novas vias de investigação para o metabolismo lipídico. As pesquisas de comparação e o desenvolvimento de mutantes com deleções têm facilitado a análise de um grande número de genes para descobrir a função, a regulação, a localização e todas as proteínas envolvidas no metabolismo lipídico. Por conta disso, vários genes envolvidos no metabolismo lipídico foram descobertos (Daum et al., 1998). Com o recente sequenciamento do genoma da levedura $Y$. lipolytica, tem sido possível comparar os genes descobertos com os genes conhecidos de $S$. cerevisiae, criar mutantes para estudar os genes ainda desconhecidos e com isso foi possível ter uma visão geral dos processos de degradação e formação de lipídios em $Y$. lipolytica, incluindo a interação com substratos hidrofóbicos, a sua absorção e transporte, e a degradação ou armazenamento desses substratos (Fickers et al., 2005). 


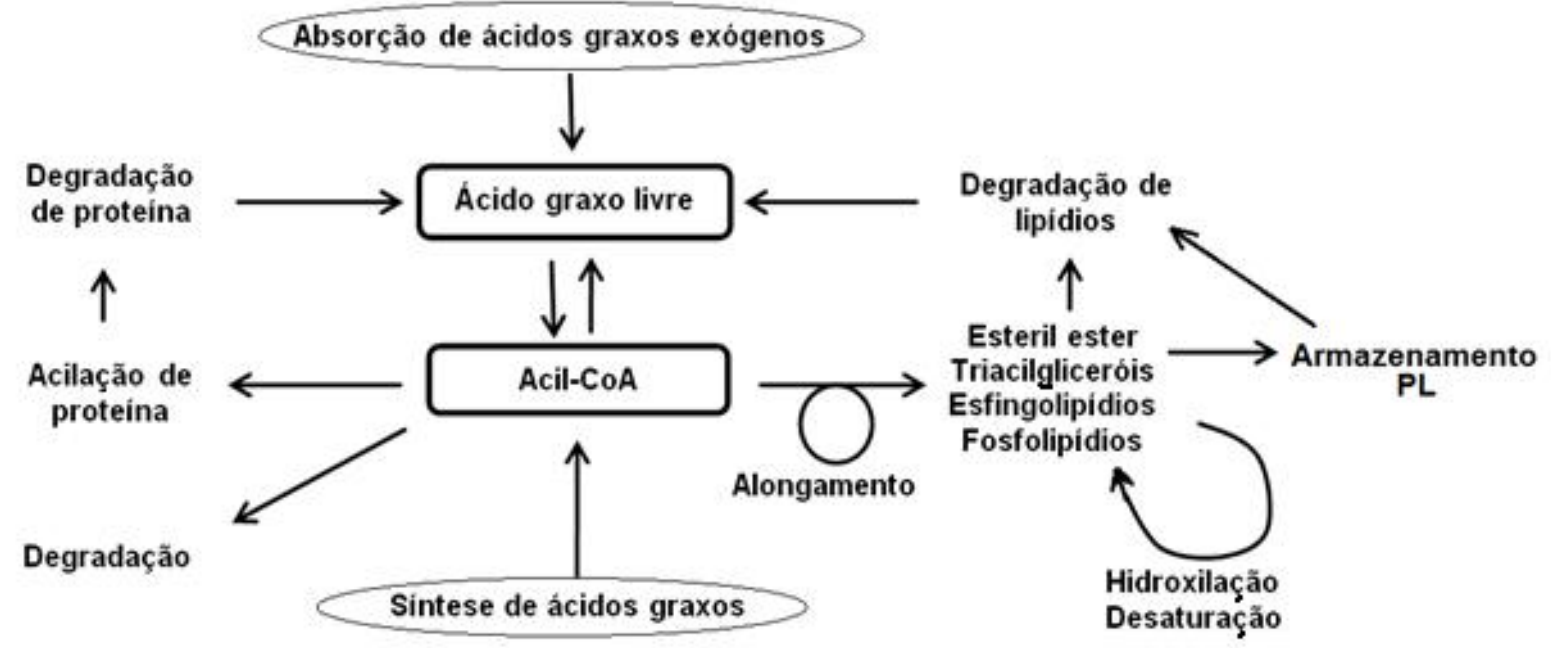

Figura 2 - Representação esquemática do metabolismo dos ácidos graxos (adaptado de Tehlivets et al., 2007).

\subsubsection{Síntese de lipídios}

Os lipídios são biomoléculas orgânicas compostas, principalmente, por moléculas de hidrogênio, oxigênio e carbono. Possuem a característica de serem insolúveis em água e servem como componentes estruturais das membranas celulares, armazenamento de energia, pigmentos e sinais intracelulares (Nelson e Cox, 2004).

Quando na fase de crescimento, uma levedura oleaginosa necessita produzir fosfolipídios para a formação das novas membranas lipídicas, mas na fase estacionária a levedura tende a acumular os lipídios na forma de lipídios neutros (TAG e EE). A transição de crescimento catalítico para o acúmulo de lipídios em geral ocorre quando o excesso de carbono no meio é associado a uma limitação de nutrientes que afetam a produção de biomassa. Além disso, durante a fase de acúmulo, precursores (acetil-CoA, malonil-CoA e glicerol) e energia (ATP, NADPH) são necessários para a síntese de lipídios. Durante a transição, algumas vias são reprimidas (síntese de ácido nucléico e síntese proteica), ao passo que outras são induzidas (síntese de ácidos graxos e triacilglicerol) (Beopoulos et al., 2009b).

$\mathrm{O}$ acúmulo de lipídios depende principalmente da fisiologia do microrganismo, da limitação de nutrientes e de outras condições ambientais, tais como temperatura e pH. Este acúmulo também é afetado pela produção de metabólitos, tais como citrato e etanol. Tem sido demonstrado em quimiostatos que o acúmulo de lipídios é 
fortemente dependente da vazão específica imposta, ou seja, da velocidade específica de crescimento do microrganismo (Gill et al., 1977; Ratledge, 1994) e da relação C/N no meio de cultura (Ykema et al., 1986; Ratledge, 1994).

Embora as estruturas moleculares das enzimas envolvidas na síntese de ácidos graxos e de alongamento de ácidos graxos sejam bastante diversificadas entre diferentes espécies de eucariotos, os mecanismos de reação são essencialmente os mesmos em todos os tipos de células (Tehlivets et al., 2007).

Para a produção de lipídios a partir de glicose, esta molécula é primeiramente oxidada a piruvato por meio da glicólise, sendo o piruvato então convertido a acetilCoA, pois a síntese lipídica em leveduras requer um fornecimento constante de ácidos graxos ativados (na forma de seus correspondentes acil-CoA's) para a acilação do esqueleto de glicerol e posterior síntese de TAG's ou esterificação dos esteróis para produzir esteril ésteres (EE). O glicerol 3-fosfato usado na síntese de TAG's é formado através da redução de dihidroxiacetona fosfato (DHAP), um intermediário glicolítico, que pode ser gerado a partir da glicose ou do glicerol (Figura 3).

Os primeiros dois átomos de carbono para a síntese de ácidos graxos são fornecidos por acetil-CoA citosólico, através da clivagem do citrato (fornecido pelo ciclo do TCA) pela ATP-citrato-liase (ACL). Então acetil-CoA é convertido em malonil-CoA através da acil carboxilase (ACC1) (Beopoulos et al., 2009b; Wang et al.,2013). A cadeia de ácidos graxos cresce através da adição de acetil-CoA a uma unidade de malonil-CoA formando acetoacetil-CoA, em seguida após várias reações envolvendo NADPH, ATP e a incorporação de mais moléculas de malonil-CoA (Ciclo de alongamento), ocorre a formação de palmitato, que é o precursor de todos os outros ácidos graxos. Por sua vez, o ácido graxo é um dos precursores para a síntese de lipídios. Para cada etapa do alongamento da cadeia de ácido graxo, duas moléculas de NADPH são necessárias. Este NADPH é gerado principalmente pela enzima málica (EM) (Fontes et al., 2008; Wang et al., 2013). 


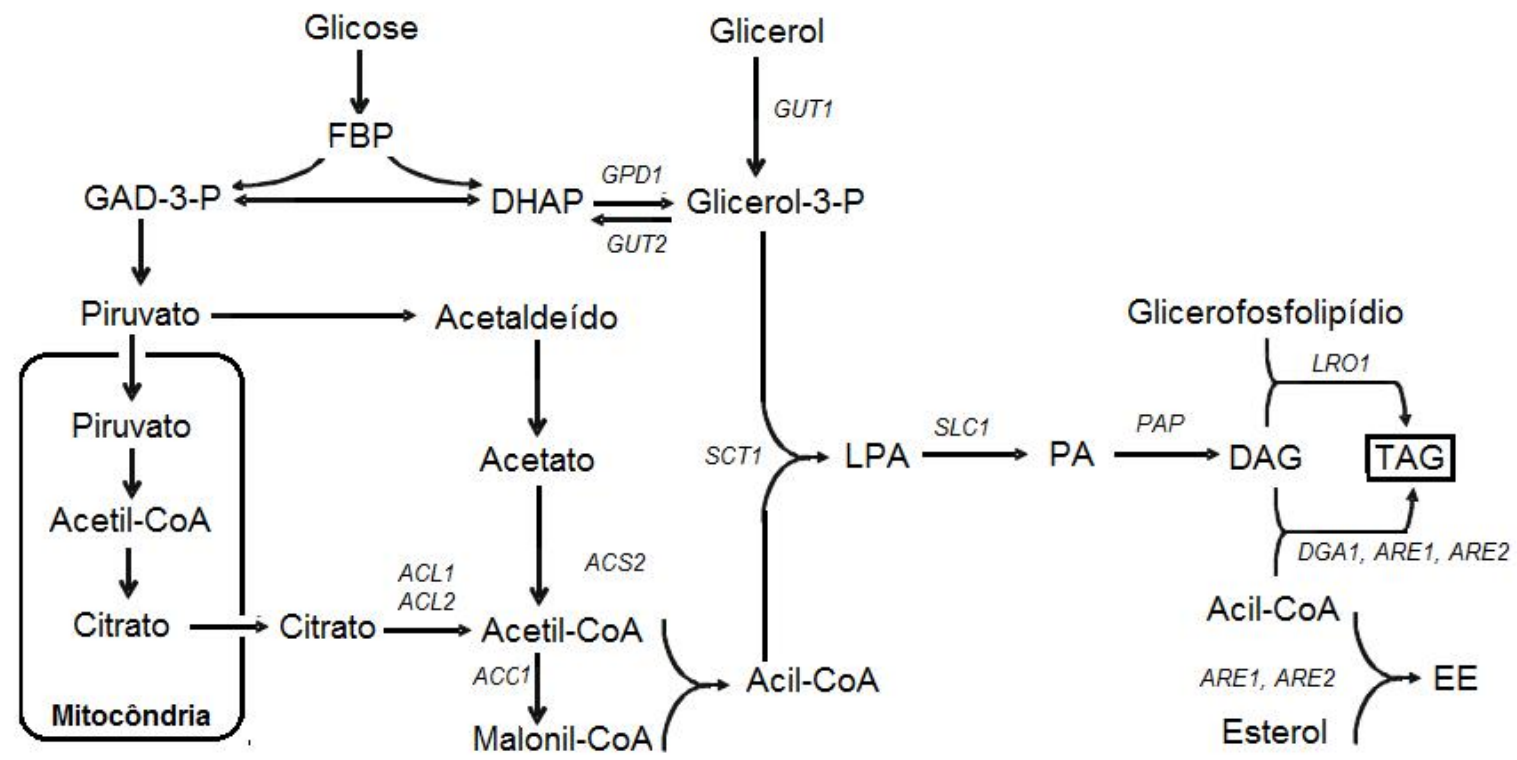

Ciclo de alongamento

Figura 3 - Síntese de lipídios neutros. O glicerol 3-P usado na síntese de TAG é formado através da redução de dihidroxiacetona fosfato (DHAP), obtida a partir da glicose ou do glicerol. O acetil-CoA citosólico é obtido através da clivagem do citrato pela ATP-citrato-liase (ACL1 e ACL2). Então acetilCoA é convertido em malonil-CoA através da acil carboxilase (ACC1) e a cadeia de ácidos graxos cresce através da adição de acetil-CoA a uma unidade de malonil-CoA seguida da incorporação de mais moléculas de malonil-CoA (Ciclo de alongamento), obtendo assim o Acil-CoA. Na síntese de TAG três grupos acila são adicionados ao Glicerol-3-P, onde primeiramente ocorre a acilação do Glicerol-3-P na posição sn-1 para gerar acil glicerol-3-fosfato (ácido lisofosfatídico; LPA), posteriormente LPA sofre mais uma acilação na posição sn-2 pela ácido lisofosfatídico aciltransferase (SLC1) para gerar ácido fosfatídico (PA). O PA é desfosforilado pela enzima ácido fosfohidrolase fosfatídica (PAP), obtendo diacilglicerol (DAG). Para a síntese final de TAG, DAG é acilada na posição sn-3, através de uma acil-CoA-dependente ou de acil-CoA-independente reação. Na via de acil-CoA independente, este terceiro grupo acila é fornecido por um glicerofosfolipídio, enquanto que, na via acil- CoA dependente é fornecido pela acil-CoA. A reação de acil-CoA-dependente é catalisada por três enzimas: Dga1p, Are1p e Are2p. A formação de esteres de esterol (EE) envolve a reação de uma molécula de ácido graxo (Acil-CoA) com um grupo hidroxila de esteróis, essa reação é catalisada pelas enzimas ARE1 e ARE2 (Adaptado de Seip, et al., 2013).

A síntese de TAG (Figura 3) geralmente segue a via de Kennedy, na qual três grupos acila são adicionados ao G-3-P para gerar TAG. Este processo envolve quatro passos catalisados por enzimas. (1) Primeiramente ocorre a acilação do glicerol-3-fosfato (G-3-P) na posição sn-1 para gerar acil glicerol-3-fosfato (ácido lisofosfatídico, LPA), (2) LPA sofre mais uma acilação na posição sn-2 pela ácido lisofosfatídico aciltransferase (SLC1) para gerar ácido fosfatídico (PA). (3) PA é desfosforilado pela enzima ácido fosfohidrolase fosfatídica (PAP), obtendo diacilglicerol (DAG). (4) Para a síntese final de TAG, DAG é acilada na posição sn-3, através de uma reação acil-CoA-dependente ou acil-CoA-independente. Na via acilCoA independente, este terceiro grupo acila é fornecido por um glicerofosfolipídio $(P L)$, enquanto que, na via acil-CoA dependente é fornecido pela acil-CoA. A reação 
acil-CoA-dependente é catalisada por três enzimas: Dga1p, Are1p e Are2p. Em Y. lipolytica, Dga1p parece ser a principal enzima envolvida na síntese de TAG, respondendo por $45 \%$ da acilação de DAG. Embora se saiba muito sobre a conversão de PA no mais complexo fosfolipídio, a biosíntese de PA em si não é totalmente compreendida (Yang et al., 2012; Daum et al., 1998; Beopoulos et al., 2009b). A biossíntese de TAG, como a de ésteres de esterol, parece envolver ambos os compartimentos, as PLs e o RE em levedura, como se mostra na Figura 4 (Murphy, 2001).

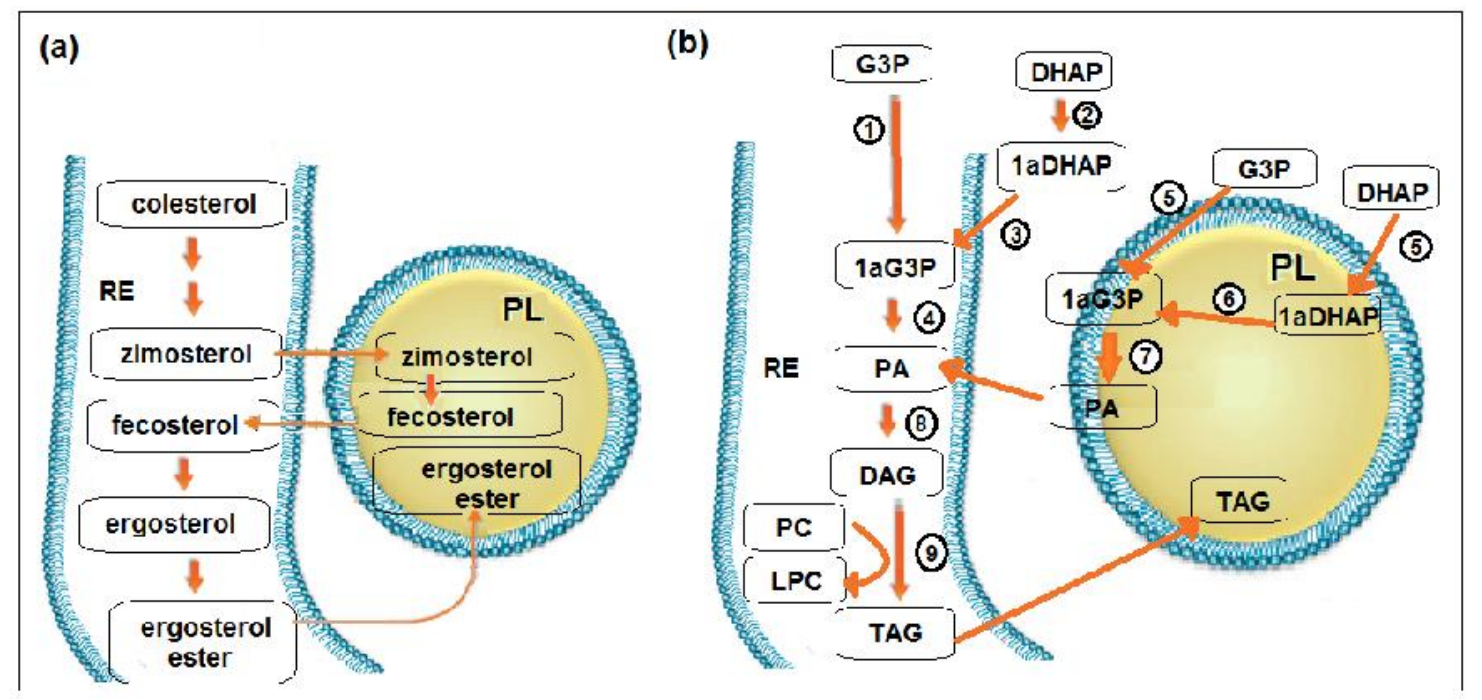

Figura 4 - Papel do RE e PLs nas vias de biossíntese de (a) de éster de esterol e (b) a biossíntese de triacilglicerol em levedura. (A) Vias de biossíntese de éster de esterol. As formas mais comuns de éster de esterol em leveduras são ésteres de ergosterol. A primeira série de enzimas responsáveis pela conversão do colesterol em zimosterol está localizada na membrana do RE. No entanto, o passo de zimosterol para fecosterol é catalisado pela enzima esterol 24-metil transferase, que é ausente no RE, mas foi mostrado ser uma das principais proteínas de PLs em leveduras. A conversão subsequente do fecosterol de ergosterol e a reação de esterificação final são mediadas por enzimas ligadas ao RE. Por conseguinte, a síntese de ésteres de ergosterol na levedura parece envolver um vai e vem de intermediários altamente hidrofóbicos entre o RE e as PLs. É possível que isto ocorra através de moléculas lipídicas solúveis, outra sugestão mais realista é uma continuidade física entre as duas organelas durante a biossíntese de éster de esterol. (B) Vias de biossíntese de triacilglicerol. A primeira aciltransferase, Gat1p, pode acilar (G3P) ou (DHAP) e é encontrada tanto em PLs quanto na membrana do RE, mas é muito mais abundante na primeira. Há também duas outras aciltransferases exclusivamente localizadas no RE, G3P-AT e DHAP-AT, que são específicas para ambos G3P ou DHAP, respectivamente. O 1-acil-DHAP é então convertido de 1-acil-G3P por uma redutase, Ayr1p, que está localizada predominantemente nas PLs e, em menor grau, no RE. O RE também contém uma extra e distinta atividade de redutase 1-acil-DHAP em adição além da que compartilha com PLs. A segunda aciltransferase, Slc1p ou 1-acil G3P-AT (LPA-AT), é também encontrada nas duas organelas, mas, tal como com ambos Gat1p e Ayr1p, a atividade Slc1p é muito mais abundante nas PLs e o RE tem outra 1-acil G3P-AT que não está presente nas PLs. A desfosforilação de PA para produzir (DAG) é realizada pela PA fosfatase. Esta atividade é altamente regulada na maioria dos organismos, uma vez que está envolvida em vias lipídicas secundárias e na formação de vesículas. Assim como a formação de ésteres de esterol, a biossíntese de TAG em levedura envolve o bidirecional vai e vem de intermediários entre o RE e as PLs (Adaptado de Murphy, 2001). 
A formação de EE envolve a reação de uma molécula de ácido graxo com um grupo hidroxila de esteróis. A síntese de EE é catalisada por uma EE sintase homóloga à humana acil-CoA-colesterol aciltransferase (ACAT) e a mobilização do EE é catalisada por EE hidrolases, que liberaram esteróis e ácidos graxos livres (Beopoulos et al., 2009b). Numerosos estudos durante a última década têm demonstrado a íntima inter-relação física e metabólica entre as PLS e o RE de levedura, pois é sabido há algum tempo que uma das enzimas de modificação de esteróis, a esterol 24 metiltransferase (SMT), enzima que catalisa a conversão do zimosterol para fecosterol (importantes na formação de EE), é possivelmente a única associada com leveduras e é encontrada somente na PL. As outras enzimas na via de biossíntese de ergosterol, incluindo a aciltransferase responsável pela sua esterificação final para formar o éster de esterol, estão todas localizadas na membrana do RE. Portanto, como se mostra na Figura 4A, a biossíntese de ésteres de ergosterol deve envolver pelo menos duas rodadas de vai e vem de intermediários entre o RE e as PLs, o que implica ou um contato físico direto entre os dois compartimentos ou um mecanismo extremamente eficiente de transporte celular para biossíntese de esterol (Murphy, 2001).

\subsubsection{Degradação de lipídios}

O catabolismo de substratos hidrofóbicos, tais como alcanos, ácidos graxos e triglicerídeos, nas leveduras, como em Yarrowia lipolytica, é bastante complexo, envolvendo várias vias metabólicas, ocorrendo em diferentes compartimentos celulares, como o retículo endoplasmático, o peroxissoma e a mitocôndria (Fickers et al., 2005).

Uma das principais etapas das vias de degradação de compostos hidrofóbicos em leveduras é a absorção e o transporte desses substratos até o local da primeira oxidação, sendo que os mecanismos inerentes a estas etapas são ainda desconhecidos. Como esses substratos não são miscíveis em água, sua absorção requer modificações morfológicas e fisiológicas, especialmente nas propriedades de adesão celular (superfície hidrofóbica) ou na produção de emulsificantes (surfactantes) (Fickers et al., 2005). 
Os triglicerídeos são primeiramente hidrolisados por enzimas lipolíticas (lipases) em ácidos graxos livres e glicerol para posterior entrada na célula; já os alcanos passam pela membrana celular diretamente. A metabolização dos alcanos ocorre primeiramente no retículo endoplasmático, onde são oxidados a seus álcoois correspondentes pela citocromo P450 monooxigenase, sendo estes posteriormente convertidos em seu ácidos graxos correspondentes e metabolizados por uma das vias descritas abaixo (Fickers et al., 2005).

Quando um hidrocarboneto é utilizado como fonte de carbono, o metabolismo microbiano se dirige principalmente à via lipolítica e à gliconeogênese, ou seja, o hidrocarboneto pode ser utilizado para produzir ácidos graxos ou sacarídeos. Os ácidos graxos podem ser armazenados como lipídios neutros (TAG e EE), como visto no item 3.2.2.1, podem ser utilizados para a produção de energia através da $\beta$ oxidação ou podem servir como substratos para as reações de acilação, por exemplo, para a síntese de fosfolipídios. DAG liberados por degradação de TAG são utilizados não só como substratos para a síntese de fosfatidilcolina e fosfatidil etanolamina pela via de Kennedy, mas também atuam como um segundo mensageiro na transdução de sinal após a ligação com proteínas-quinase (Murphy, 2001).

Quando necessário, os lipídios neutros armazenados são mobilizados pela ação de lipases e hidrolases, e os produtos da clivagem são usados como blocos de construção para a formação da membrana, ou como mensageiros celulares ou para produção de energia (Murphy, 2001). A produção de energia consiste na ativação dos ácidos graxos no retículo endoplasmático ou no peroxissoma, antes de entrarem na via da $\beta$-oxidação, em que ocorre sua transformação em acetil-CoA e propionilCoA (no caso de alcanos de cadeias ímpares). Esses intermediários metabólicos produzidos na $\beta$-oxidação entram no ciclo do glioxalato, o qual interage com o ciclo TCA e o ciclo de metilcitrato na mitocôndria. (Beopoulos et al., 2009a; Fickers et al., 2005).

Ao contrário do que se observa em células de mamíferos e em fungos filamentosos, em que a $\beta$-oxidação ocorre nas mitocôndrias e nos peroxissomas, em levedura esta via metabólica é limitada apenas ao peroxissoma (Beopoulos et al., 2009a). 


\subsubsection{Via de degradação por $\beta$-oxidação}

A via de $\beta$-oxidação para degradação de ácidos graxos em Y. lipolytica ocorre nos peroxissomas e tem sido extensivamente documentada (Wang et al., 1999;. Mlickova et al., 2004).

O primeiro passo para a degradação dos ácidos graxos consiste na oxidação dos mesmos para acil-CoA (desidrogenação), catalisada pela acil-CoA oxidase (AOX). Y. lipolytica contém seis isoformas AOX (codificadas pelos genes POX1-6), cada uma com diferentes atividades e especificidades para o substrato, incluindo Aox2p e Aox3p que apresentam especificidade para ácidos graxos de cadeia longa.

O segundo passo (hidratação) e terceiro passo (oxidação) são catalisados pela enzima multifuncional (MFE1) que exibe atividades hidratase e desidrogenase (Figura 5). O quarto passo é catalisado pela 3-cetoacil-CoA-tiolase (THIO1) que libera uma molécula de acetil-CoA e molécula de acil-CoA encurtada em 2 átomos de carbono.

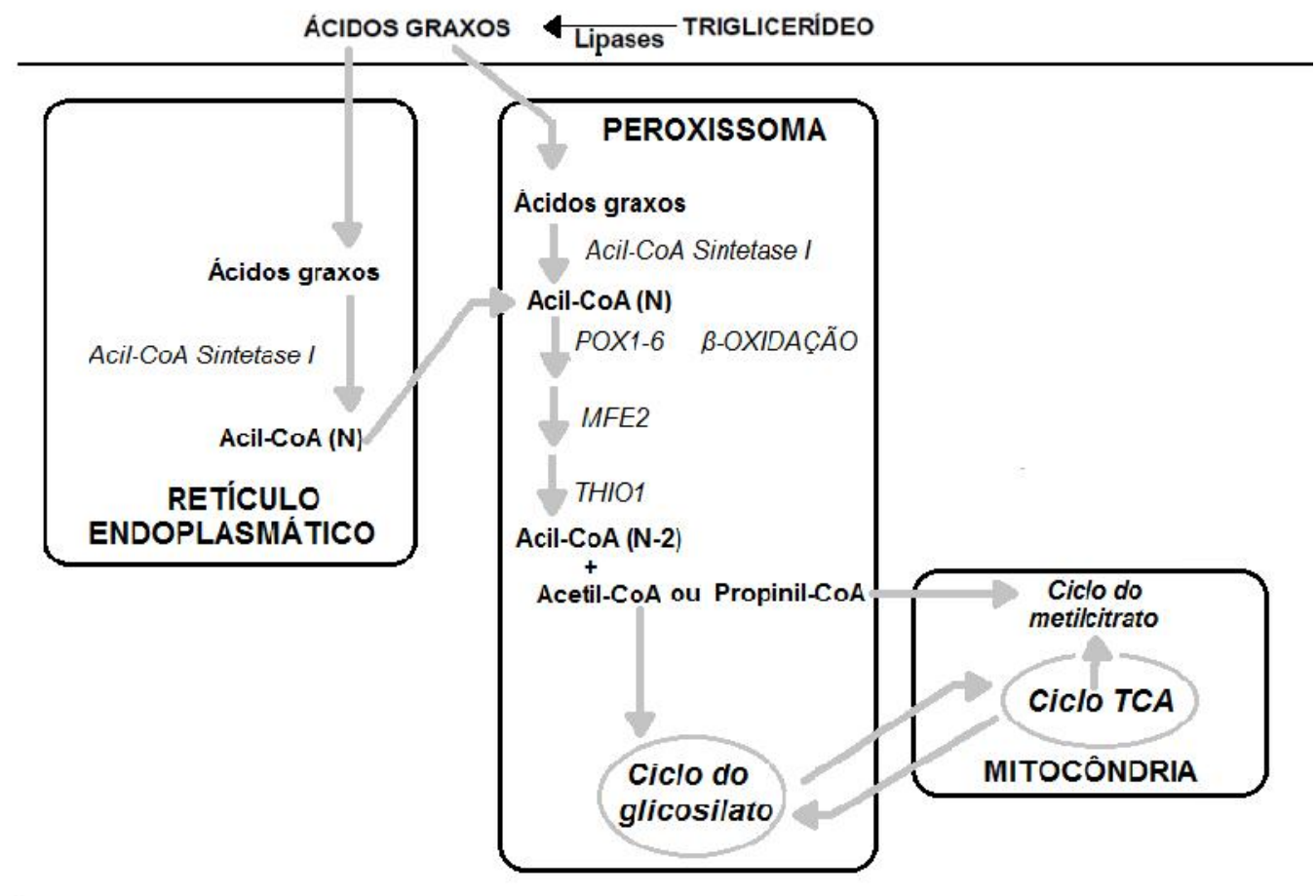

Figura 5 - Descrição geral da via de degradação de lipídios não polares. O acido graxo livre é oxidado a acil-CoA e pode então ser degradado na via da $\beta$-oxidação, no peroxissoma, que envolve acil-CoA oxidase (POX), a enzima multifuncional (MFE1) e a 3-cetoacil-CoA-tiolase (THIO1). (Adaptado de Ferreira, 2009). 
No caso de um ácido graxo saturado, este ciclo de quatro reações é repetido várias vezes até a completa degradação de ácidos graxos em moléculas de acetilCoA. Alterações na $\beta$-oxidação ou abolição completa do fluxo desse processo pode aumentar o acúmulo de lipídios (Beopoulos et al., 2009b; Endrizzi et al.,1996).

\subsection{PARTÍCULAS LIPÍDICAS (PLs)}

Todos os tipos de células eucarióticas, como as de plantas, de mamíferos, de algas e de leveduras contém partículas lipídicas intracelulares (Figura 6a). Embora diferentes em tamanho e composição, exercem funções semelhantes em todos os tipos de células. Estas partículas são também conhecidas como corpos lipídicos, corpúsculos lipídicos, partículas lipídicas, partículas lipídio-proteicas, gotículas de gordura, vacúolos lipídicos, lipoproteínas, gotículas lipídicas e, especialmente em plantas, corpos de óleo, óleossomos ou esferossomos. Os nomes diferentes são muitas vezes simples convenções que podem ser aplicadas em um campo específico, como gotículas lipídicas é o nome comumente usado em adipócitos, glóbulo lipídico é usado para células mamárias, corpos lipídicos para fungos, mas a falta de uma terminologia consistente tem dificultado a análise comparativa dessas organelas lipídicas (Murphy, 2001; Zweytick et al., 2000).

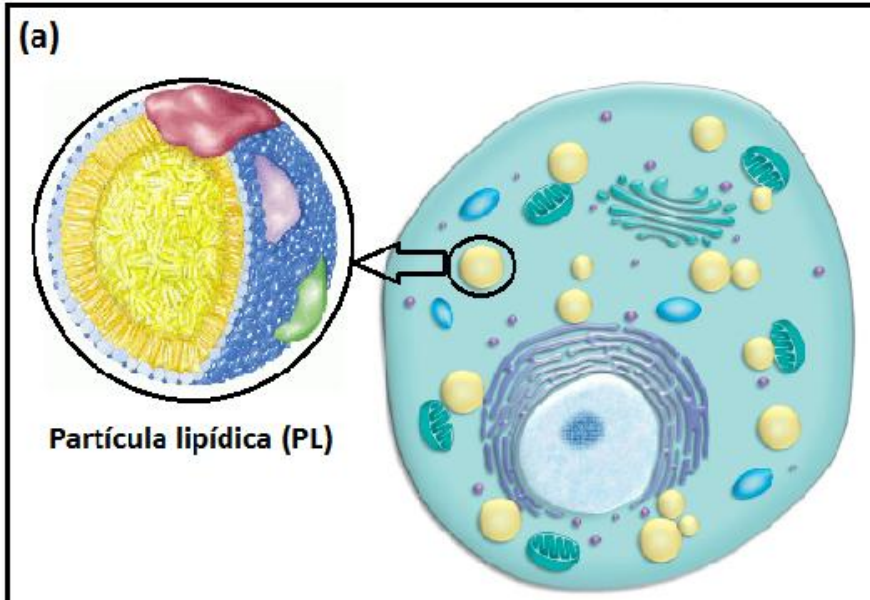

(b)

Figura 6 - Partículas lipídicas (PLs) são heterogêneas em tamanho. (a) Múltiplas PLs pequenas. A maioria das células sintetiza múltiplas PLs pequenas para acomodar mais lipídios neutros. Fatores como seipin e fosfatidilcolina podem ajudar a manter PLs pequenas. (b) Gigantes/Super PLs. Adipócitos brancos ou células cultivadas em condições "extremas" (por exemplo, períodos prolongados em ácido oleico), ou determinadas células mutantes (por exemplo, células em que faltam seipin ou CTP: fosfocolina citidil transferase) podem sintetizar Gigantes/Super PLs. Os fatores que podem promover a formação de células Gigantes/Super PLs incluem FITM1/2, Fsp27/Cidea, perilipin1 e ácido fosfatídico (Adaptado de Yang, et al., 2012) 
Os lipídios, além de serem armazenados na forma de lipídios neutros como fonte de energia, também fornecem componentes necessários para a biogênese da membrana (ácidos graxos para a formação de fosfolipídios de membrana) e formação de determinados componentes lipofílicos (hormônios esteróides) (Beopoulos et al., 2009a; Zweytick et al., 2000).

Originalmente, as PLs foram apenas consideradas como um depósito de lipídios neutros que podem ser mobilizados pelas células durante períodos de falta de nutrientes. No entanto, na última década, a imagem de PLs como um simples compartimento de armazenamento teve de ser revista, pois muitas proteínas foram identificadas nas PLs e foi comprovado que as mesmas desempenham papéis importantes no armazenamento, na biossíntese, no metabolismo e na degradação de lipídios, além de atuarem no tráfego de substratos. Essas proteínas também podem estar envolvidas em atividades aparentemente não relacionadas, como sinalização celular, armazenamento de proteínas, degradação de proteínas, entre outras (Athenstaedt et al., 2006; Fujimoto et al., 2008).

A relação de partículas lipídicas com outros compartimentos celulares e a interação com outras organelas parece ser de importância fisiológica, pois as partículas lipídicas de todas as células eucarióticas interagem com o retículo endoplasmático. As partículas lipídicas de mamíferos também foram detectadas em proximidade com mitocôndrias, e as partículas lipídicas de leveduras são associadas com o vacúolo. Acredita-se que a interação de partículas lipídicas com o retículo endoplasmático pode ser a chave para a compreensão da biossíntese destas partículas (Zweytick et al., 2000).

Muitos estudos fundamentais sobre PL's e metabolismo lipídico foram realizados em leveduras, sendo a maioria realizado com a levedura Saccharomyces cerevisiae, que não é uma levedura oleaginosa e que acumula apenas moderada quantidade de lipídios (menos de $15 \%$ da sua biomassa seca). Em contrapartida, as informações sobre PL's na levedura oleaginosa $Y$. lipolytica são limitadas (Beopoulos et al., 2009b).

Mortierella ramanniana é uma espécie de fungo oleaginoso em que foram realizados estudos detalhados sobre a formação de lipídios. Esse fungo consegue acumular até $40 \%$ de sua biomassa seca como lipídio, quando cultivado em meio contendo elevada concentração de fonte de carbono (Kamisaka et al., 1999). 
Em S. cerevisiae foi relatado que as PLs contêm principalmente, se não exclusivamente, enzimas envolvidas no catabolismo de lipídios neutros, enquanto que as enzimas de biossíntese são consideradas presentes exclusivamente no retículo endoplasmático (RE) (Czabany et al., 2007). Na levedura oleaginosa Yarrowia lipolytica, a análise de proteínas da PL evidenciou enzimas anabólicas e catabólicas, bem como proteínas que controlam o tráfego de vesícula, uma situação que lembra claramente o que é descrito em células de adipócitos (Athenstaedt e Daum, 2006; Beopoulos et al., 2011b).

O tamanho das PLs pode ser bem diverso, podendo variar dependendo da espécie, da linhagem e das condições de cultivo. Em Mortierellara manniana foram descritas PLs com diâmetro de 1 a $3 \mu \mathrm{m}$, em $S$. cerevisiae foram descritas PLs de 0,3 a 0,4 $\mu \mathrm{m}$, embora alguns corpos maiores de 1,2-1,6 $\mu \mathrm{m}$ foram também observados. Em leveduras são encontradas PLs com diâmetro em torno de 0,4 $\mu \mathrm{m}$, sendo que leveduras geneticamente modificadas podem formar PLs com diâmetros bem maiores (Figura 6b), podendo chegar a diâmetros maiores que $1 \mu \mathrm{m}$. Mesmo dentro do mesmo tipo de célula, o tamanho das PLs pode sofrer alterações drásticas em resposta a estímulos internos e externos (Yang et al., 2012; Beopoulos et al., 2008; Beopoulos et al., 2009b; Fei et al., 2011).

Embora o sequenciamento do genoma tenha revelado informações importantes sobre o metabolismo lipídico em Y. lipolytica, a formação de partículas lipídicas e as vias de sinalização que regulam o acúmulo e a degradação dos estoques intracelulares de lipídios não foram profundamente estudados (Yang et al., 2012; Beopoulos et al., 2009b).

\subsection{FORMAÇÃO E CRESCIMENTO DE PLS}

PLs são agora reconhecidas como organelas multifuncionais que afetam muitos aspectos da biologia celular e do metabolismo. No entanto, questões fundamentais relativas à biogênese e ao crescimento de PLs permanecem sem resposta (Yang et al., 2012). O modelo atual de formação de PLs conta com um processo de brotamento, em que a origem das PLs é o reticulo endoplasmático. Sugeriu-se que gotículas de lipídios neutros são formadas entre as duas camadas da bicamada membranar do retículo endoplasmático e brotam depois de atingir um 
determinado tamanho. Evidências apoiando a hipótese de brotamento foram fornecidas em vários estudos (Fujimoto et al., 2008).

Athenstaedt et al.(2006) constataram o aumento do número e tamanho das PLs ao transferir a levedura $Y$. lipolytica de um meio contendo glicose como fonte de carbono para um meio contendo ácido oleico. O aumento do tamanho das PLs exige a incorporação de mais lipídios neutros no núcleo hidrofóbico do compartimento e o aumento dos fosfolipídios de superfície que são sintetizados em primeiro lugar no RE, uma possibilidade de proporcionar estes componentes é a síntese de novo pelas proteínas da PL, e/ou crescimento através do transporte de vesícula (Figura $7 b)$.

As PLs são frequentemente encontradas muito próximas ao RE, o que gera suposições como: um possível contato entre as PLs e o RE, ou a monocamada fosfolipídica das PLs estar próxima a membrana do RE, ou também as PLs serem subdomínios do RE.

Atualmente, pelo menos três hipóteses de como as PLs podem crescer foram levantadas. Uma das hipóteses é a síntese de fosfolipídios e lipídios de armazenamento no RE, que seriam posteriormente entregues às PLs em crescimento através de sítios de ligação entre as PLs e o RE ou através do aumento da divisão de lipídios neutros nos subdomínios PL (Figura 7a-i). Outra hipótese para o crescimento das PLs surge a partir das observações de enzimas chave na síntese de fosfolipídios e de lipídios neutros presentes na superfície das PLs, podendo assim acumular mais lipídios através da síntese na própria PL (Figura 7a-ii). Por último, existe a hipótese de PLs crescerem através da fusão de PLs existentes (Figura 7b), esse modelo de crescimento por fusão tem sido controverso, mas é atraente em parte porque a fusão de membranas vesiculares é um evento frequente em eucariotos (Yang et al., 2012). 


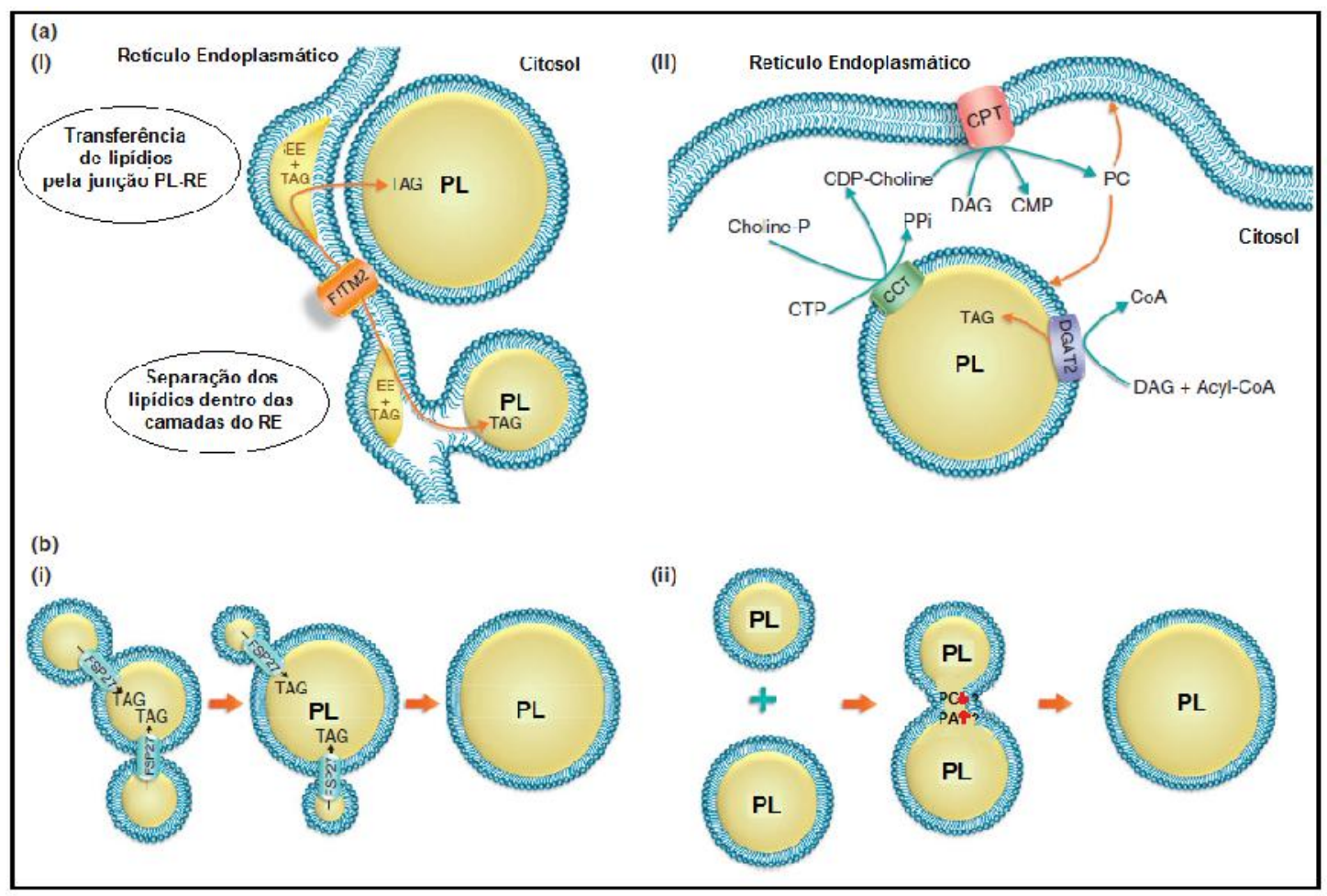

Figura 7 - O crescimento de partículas lipídicas (PL). (a) PLs podem crescer por meio da aquisição de lipídios através da entrega direcionada e síntese local. (i) A entrega de lipídio direcionada: Entrega direcionada/particionada de lipídios neutros, por exemplo, triacilgliceróis (TAG) em PLs na junção PLRE e dentro da bicamada membranar do RE. FITM1/2 pode facilitar a entrega e/ou particionar o TAG. (ii) A síntese local de lipídios: triacilgliceróis (TAG) e CDP-colina, precursores da síntese de fosfatidil colina (PC), são sintetizados diretamente nas PLs. Enzimas chave envolvidas na síntese de PC (CCT, CTP: fosfocolina citidil transferase), e na síntese de TAG (DGAT2, diacilglicerol O-aciltransferase 2) estão presentes na superfície de PL. DAG: diacilglicerol; CPT: CDP-choline:1, 2 diacilglicerol fosfotransferase; colina-P: fosfocolina. (b) PLs podem crescer através da fusão com PLs existentes. (i) PLs podem crescer através da Fsp27 mediando à troca/fusão atípica. Lipídios neutros, por exemplo, triacilgliceróis (TAG), podem trocar livremente através dos sítios de contato das PLs enriquecidas com Fsp27, mas o direcionamento global dos lipídios neutros, isto é, de pequenas para grandes PLs, é impulsionado pela maior pressão no interior da menor PL para outra PL. O mediador Fsp27 de transferência lipídica/fusão atípica leva horas para se completar, e parece ser um modo essencial de crescimento de PL em adipócitos. (ii) PLs podem crescer através da rápida fusão homotípica de PL em adipócitos, e também em alguns mutantes, por exemplo, células deficientes em seipin ou em fosfatidil colina (PC). As alterações específicas na composição de fosfolipídios da superfície da PL, por exemplo, um aumento do ácido fosfatídico (PA) e/ou uma diminuição de fosfatidil colina (PC), podem facilitar a junção das partículas lipídicas. Fatores proteicos que medeiam este tipo de PL fusão permanecem desconhecidos (Adaptado de Yang, et al., 2012).

Alguns fatores podem afetar o acúmulo de lipídios, como a fisiologia do microrganismo, a limitação de nutrientes e as condições ambientais como temperatura e pH. O acúmulo de lipídios também pode ser afetado pela produção de metabólitos como citrato e etanol (Beopoulos et al., 2009b).

Durante o crescimento, as leveduras não tendem a acumular lipídios, pois toda a produção dessas moléculas se destina ao crescimento e à formação da membrana celular. A transição de crescimento catalítico para o acúmulo de lipídios em geral 
ocorre quando o excesso de carbono no meio é associado a uma limitação de nutrientes que afeta a produção de biomassa (novas células) (Beopoulos et al., 2009b).

\subsection{CULTIVOS EM RESTRIÇÃO DE NITROGÊNIO}

A amônia pode ser usada como única fonte de nitrogênio por diversos microrganismos. Nesta molécula, o estado de oxidação do átomo de nitrogênio (-III) é o mesmo que dos átomos de $\mathrm{N}$ presentes em aminoácidos, o que faz com que a amônia seja considerada uma boa fonte de nitrogênio. No primeiro passo do seu metabolismo, a amônia e o $\alpha$-cetoglutarato (um intermediário do ciclo TCA) são convertidos em glutamato pela enzima glutamato desidrogenase NADPHdependente (NADPH-GDH). Posteriormente, glutamato e amônia são convertidos em glutamina pela enzima glutamina sintetase (GS). O glutamato e a glutamina são usados como doadores de amina em várias reações biossintéticas, sendo que a glutamina também pode ser usada como fonte de nitrogênio e, neste caso, glutamato é gerado no meio intracelular (ter Schure et al., 1998).

Vários estudos envolvendo cultivos sob limitação de nitrogênio foram realizados com leveduras e observaram-se mudanças no metabolismo da levedura S. cerevisiae, nestas condições, em relação a situações com excesso de nitrogênio. Larsson et al. (1993) observaram, com o início da restrição de nitrogênio no cultivo, uma limitação na biomassa formada e um aumento na taxa de respiração. Quando a capacidade respiratória se tornou saturada foi observado um aumento na taxa de fermentação. Observaram também a redução do fluxo anabólico de glicose que foi totalmente ou pelo menos parcialmente compensado por um aumento do consumo catabólico de glicose.

Um aumento do catabolismo em comparação com o fluxo anabólico pode resultar em um excesso de produção de ATP a menos que as células sejam capazes de ajustar a quantidade de ATP produzido ou o rendimento de ATP. Um aumento da taxa de fermentação, em relação à respiração, pode ser uma forma de produzir menos ATP quando a necessidade de ATP é reduzida na via anabólica por causa da quantidade limitada de nitrogênio (Larsson et al., 1997). 
ter Schure et al. (1995a) constataram que em S. cerevisiae com o aumento da taxa de diluição, em cultivo contínuo sob limitação de nitrogênio, as atividades do gene regulado por nitrogênio (GAP1) e as enzimas reguladas por nitrogênio (NADPH-GDH, NAD-GDH e GS) são moduladas gradualmente. E essa modulação ocorre através da concentração de nitrogênio extracelular ao invés da glutamina ou do glutamato intracelular.

Posteriormente, ter Schure et al. (1995b) constataram experimentalmente que o fluxo de amônia manteve-se constante apesar do aumento da concentração de amônia no meio de cultivo, indicando que as mudanças observadas no metabolismo do nitrogênio são reguladas por ambas as concentrações de amônia (intracelular e extra celular), ou pelas mudanças nos metabólitos intracelulares com $\alpha$ cetoglutarato, glutamato ou glutamina.

Analogamente ao relatado no trabalho de Lillie e Pringle (1980) foi observado por Parrou et al. (1999), em cultivo sob limitação de nitrogênio, que tanto glicogênio quanto trealose começaram a se acumular no momento preciso em que a fonte de nitrogênio foi esgotada do meio, e coincidentemente houve a ativação da transcrição de genes envolvidos no seu metabolismo. Embora esta resposta à limitação de nitrogênio foi provavelmente mediada pelos elementos responsivos ao estresse (STREs) no promotor destes genes, verificou-se que estes elementos não eram responsáveis pela co-indução de genes envolvidos no metabolismo de reserva de carboidratos durante a limitação de glucose, desde que GLG1, que não contém qualquer STRE, foi coordenadamente induzida com GSY2 e TPS1.

Na levedura $Y$. lipolytica, como citado anteriormente nos itens 3.2.1, 3.2.2.1 e 3.4, a síntese e o acúmulo de lipídios são induzidos em condições de limitação de nitrogênio (ou uma proporção elevada de $\mathrm{C} / \mathrm{N}$ ). No entanto, os mecanismos de regulação dessa indução ainda não foram identificados (Seip, et al., 2013).

Seip et al. (2013) estudaram o gene Snfl como um regulador da acumulação de lipídios em Y. lipolytica. Resumidamente, foi observado que a exaustão do nitrogênio no meio resulta na estimulação da AMP deaminase, que degrada AMP a IMP e amônio, a fim de poupar nitrogênio. A diminuição da concentração de AMP inibe a enzima isocitrato desidrogenase, e o isocitrato acumulado é equilibrado através da aconitase que o converte em citrato. $O$ citrato posteriormente sai da mitocôndria e é convertido a acetil-CoA, por geração citosólica pela ATP-citrato-liase $(A C L)$. A atividade da enzima ACL é crítica para a síntese de lipídios, bem como da 
enzima málica, que é importante para o fornecimento de NADPH para a síntese de ácidos graxos em microrganismos oleaginosos. Embora Beopoulos et al. (2009b) tenham encontrado homólogos destas enzimas em $Y$. lipolytica, não existem muitos estudos bioquímicos das mesmas nesta levedura. Também continua a ser examinado se o mecanismo é aplicável a outras limitações nutricionais que induzem à acumulação de lipídios, como as limitações de fósforo, magnésio ou enxofre.

\subsection{BIODIESEL}

Questões relacionadas ao meio-ambiente e ao esgotamento do suprimento de petróleo estão se tornando desafios importantes na atualidade. Desta maneira, surgem cada vez mais iniciativas relacionadas ao desenvolvimento de biocombustíveis de primeira e de segunda geração, a partir de biomassa vegetal e/ou de resíduos agroindustriais. O biodiesel é um biocombustível gerado a partir da transesterificação de ácidos graxos com álcoois, apresentando as vantagens, em relação ao diesel obtido de petróleo, de ser mais biodegradável, menos tóxico e essencialmente livre de enxofre e de compostos aromáticos (Gui et al., 2008).

No entanto, a produção de biodiesel ainda encontra várias dificuldades. Em primeiro lugar, em sua fabricação são usados majoritariamente óleos vegetais comestíveis, o que gera um debate sobre o conflito entre o uso da terra para a produção de alimentos ou para a produção de biocombustíveis (Gui et al., 2008). Neste contexto, muitos estudos estão sendo realizados com o objetivo de se desenvolver tecnologias que permitam a obtenção de óleos a partir do cultivo de microrganismos, o que poderia evitar ou ao menos diminuir o uso dos óleos vegetais comestíveis na fabricação do biodiesel. Os óleos microbianos possuem muitas vezes uma composição e um valor energético similar aos apresentados por óleos vegetais e animais, com as potenciais vantagens adicionais além da não competição direta com os alimentos já mensionada, de apresentarem um ciclo de processo mais curto e de serem independentes da época de produção e de fatores climáticos (Beopoulos et al., 2011). No entanto, alguns pesquisadores questionam a viabilidade econômica da produção de óleo microbiano (SCO) (Fakas et al., 2009).

Outra dificuldade na produção de biodiesel é que, apesar de sua produção se encontrar em crescimento acelerado, ainda possui um alto custo em relação a outros 
combustíveis. Também a quantidade de glicerol gerado é aproximadamente $10 \%$ do volume de biodiesel produzido, sendo que esse glicerol produto da transesterificação apresenta impurezas como água, sais, ésteres, álcool e óleo residual, e o tratamento e purificação deste resíduo elevam ainda mais os custos. Para tornar a produção de biodiesel mais rentável, é necessário implementar estratégias biotecnológicas que utilizem o excedente de glicerol para obtenção de produtos de maior valor agregado.

Os mercados tradicionais do glicerol possuem uma capacidade limitada de absorção de quantidades maiores do produto, tanto o gerado pela indústria do biodiesel quanto o glicerol gerado como subproduto por várias outras indústrias (como a saponificação de gordura e unidades de produção de bebidas alcoólicas). Os preços do glicerol estão diminuindo, e tendem a diminuir mais, o que torna o glicerol uma fonte de carbono de origem renovável muito importante para a produção microbiana (Wen et al., 2009).

Vários processos biotecnológicos foram desenvolvidos buscando formas eficientes de exploração do glicerol, como por exemplo, a produção de 2,3butanodiol, 1,3-propanodiol, a vitamina B12, o ácido propiônico, etanol, o ácido succínico, lipídios, o ácido cítrico e outros (Celińska e Grajek, 2013). Morita et al. (2006) utilizaram glicerol para produção de glicolipídios pela levedura Pseudozyma antarctica, obtendo uma produção de 16,3 g/L do biossurfactante após sete dias de cultivo. A biossíntese de soforolipídios por $C$. bombicola foi também realizada utilizando-se do subproduto da produção do biodiesel. A produção de soforolipídios foi de $60 \mathrm{~g} / \mathrm{L}$ (Fontes et al., 2008).

Também existe o interesse no reaproveitamento direto do glicerol, sem tratamento (Rech, 2011). Como exemplo, Rywin'ska et al. (2009) estudaram o uso de glicerol bruto, como substrato, e observaram que o mesmo não afetou a formação de biomassa nas linhagens estudadas de $Y$. lipolytica. Esta levedura consegue utilizar o glicerol como fonte de carbono única e convertê-lo em lipídios ou em outros produtos de interesse como ácidos orgânicos. Além de possuir um grande potencial para ser usada na produção de SCO, com o objetivo de produzir biodiesel, pois a composição em ácidos graxos dos lipídios acumulados por esta levedura é muito apropriada para tal finalidade: 14,7 a $23,1 \%$ de ácido palmítico (16:0), 47,1 a 68,3\% de ácido esteárico (18:0), 6,9 a 18,2\% de ácido oleico (18:1) e 2,2 a 8,9\% de ácido linolénico (18:2) (Coelho et al., 2010). 


\subsection{CULTIVOS EM QUIMIOSTATO}

Um cultivo microbiano em batelada sofre muitas alterações em virtude da atividade metabólica dos microrganismos em crescimento. Nos estágios finais do cultivo, quando o número de células se torna elevado, ocorrem alterações drásticas na composição química e física do meio. Em muitos estudos é necessário manter as células em condições ambientais invariáveis como, por exemplo, em estudos fisiológicos quantitativos. Isto só é possível através do emprego de culturas contínuas, em que o volume de meio de cultivo é mantido constante pela adição de meio fresco e pela retirada de meio com células a uma determinada vazão específica (relação entre vazão de saída de meio e volume de meio dentro do frasco de cultivo ou biorreator). Este tipo de sistema tem a característica de entrar em equilíbrio, situação na qual as principais variáveis de cultivo, como concentração celular e de metabólitos, assumem um valor constante ao longo do tempo. Esta situação é denominada estado estacionário e estes cultivos contínuos, em que um dos nutrientes do meio de cultivo é limitante do crescimento dentro do frasco de cultivo ou biorreator, denomina-se quimiostato. Nesta configuração é possível controlar não somente variáveis como o pH, a temperatura e a concentração de oxigênio dissolvido, mas também a própria velocidade específica de crescimento do microrganismo, que assume valor igual à vazão específica no estado estacionário. Através da manipulação da concentração do nutriente limitante no frasco de alimentação, pode-se também controlar a concentração celular dentro do biorreator. Assim, a concentração celular e a velocidade específica de crescimento de uma população microbiana podem ser manipuladas pelo experimentador de maneira independente uma da outra, garantindo grande flexibilidade de operação (Madigan et al., 2010).

Segundo Regenberg et al. (2006), cerca de metade de todos os genes de levedura tem sua expressão alterada em função da velocidade específica de crescimento e estas alterações são semelhantes, independentemente do tipo de estresse ao qual as células são expostas. Os genes que sofrem diminuição da transcrição em resposta a um crescimento mais rápido são na maioria de função desconhecida; enquanto que genes com maiores níveis de transcrição, numa situação de mais alta velocidade específica de crescimento, estão envolvidos na biossíntese de macromoléculas, como as que codificam proteínas ribossomais. A 
maioria desses genes são ativados pelo ativador transcricional RAP1, envolvido na replicação.

A velocidade específica de crescimento tem grande influência na regulação da transcrição, o que implica na necessidade de cuidado na realização de experimentos, quando se deseja comparar linhagens com diferentes velocidades específicas máximas de crescimento. Através do cultivo em quimiostato pode-se impor uma determinada vazão específica de alimentação, controlando assim a velocidade específica de crescimento das células, ou seja, é possível fixar as células em um mesmo estado fisiológico (Schmidell et al., 2001). Dado que a velocidade específica de crescimento é inversamente proporcional ao tempo de duplicação das células $T_{d}$, equação 1 , é possível modificar os tempos de duplicação das células de uma maneira controlada em culturas contínuas e aumentar o nível de transcrição de determinados genes, principalmente daqueles envolvidos no metabolismo de RNA e na biossíntese de material para novas células (Regenberg et al., 2006).

$$
\mathrm{T}_{\mathrm{d}}=\ln (2) /
$$




\section{MÉTODOS}

\subsection{LINHAGENS}

Foram utilizadas as seguintes linhagens de levedura: Yarrowia lipolytica IMUFRJ 50682, isolada da Baia da Guanabara no Rio de Janeiro (Hagler e Mendonça-Hagler, 1981), e Yarrowia lipolytica w29 (CLB89: ATCC20460: CBS057504), linhagem amplamente estudada na comunidade acadêmica (Wu et al., 2009; Barth e Gaillardin, 1996; Nicaud et al., 2002; Nicaud et al., 2011; Tai et al., 2013; Haddouche et al., 2010; Athenstaedt et al., 2006). As linhagens foram cedidas pela Prof ${ }^{\mathrm{a}}$. Dr ${ }^{\mathrm{a}}$. Maria Alice Zarur Coelho (UFRJ) e mantidas em estoque a $-80^{\circ} \mathrm{C}$ em água destilada estéril com 30\% de glicerol.

\subsection{MEIOS DE CULTURA}

Os meios de cultura tiveram suas composições obtidas da literatura científica e algumas substituições de componentes foram realizadas em função da disponibilidade de reagentes em nosso laboratório. As composições dos meios de cultura de composição totalmente definida usados neste trabalho encontram-se descritas na Tabela 1.

O meio YNB (Yeast nitrogen nase without amino acids) da Becton, Dickinson and Company (BD, New Jersey, EUA) é um meio comercial, completamente definido, com fonte de nitrogênio (sem adição de aminoácidos) e vitaminas, ao qual somente foi acrescentada a fonte de carbono desejada.

O meio definido LUTTIK, descrito por Luttik et al. (2000), é um meio de composição muito parecida à do meio VERDUYN (Verduyn et al., 1992), adaptado para cultivos em frasco agitado, em que se substitui a fonte de nitrogênio, sulfato de amônio $\left(\left(\mathrm{NH}_{4}\right)_{2} \mathrm{SO}_{4}\right)$, por ureia $\left(\mathrm{NH}_{2} \mathrm{CONH}_{2}\right)$. Com isto, ocorre uma menor variação do $\mathrm{pH}$ ao longo do cultivo.

O meio definido NICAUD foi descrito por Nicaud et al. (2002) para o cultivo da levedura Yarrowia lipolytica. O meio PAPANIKOLAOU foi descrito por Papanikolaou et al. (2001); este meio inclui originalmente a adição de extrato de levedura como 
promotor de crescimento, o que o torna complexo. Neste trabalho, o meio foi utilizado em duas formas, com ou sem extrato de levedura.

Tabela 1 - Composição dos meios de cultura definidos empregados neste trabalho*.

\begin{tabular}{|c|c|c|c|c|c|c|}
\hline & 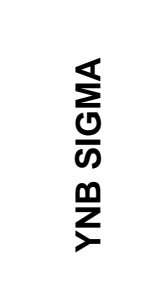 & 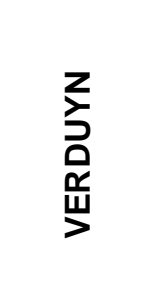 & 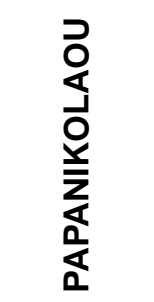 & $\underset{\Xi}{\underline{E}}$ & 号 & 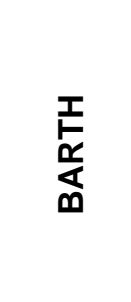 \\
\hline Fosfato de potássio monobásico & $1 \mathrm{~g} / \mathrm{L}$ & $3 \mathrm{~g} / \mathrm{L}$ & $7 \mathrm{~g} / \mathrm{L}$ & $3 \mathrm{~g} / \mathrm{L}$ & $10 \mathrm{~g} / \mathrm{L}$ & $2,5 \mathrm{~g} / \mathrm{L}$ \\
\hline Sulfato de potássio & & & & $6,6 \mathrm{~g} / \mathrm{L}$ & & \\
\hline Sulfato de amônio & $5 \mathrm{~g} / \mathrm{L}$ & $5 \mathrm{~g} / \mathrm{L}$ & $0,5 \mathrm{~g} / \mathrm{L}$ & & & $3 \mathrm{~g} / \mathrm{L}$ \\
\hline Ureia & & & & $2,3 \mathrm{~g} / \mathrm{L}$ & $3 \mathrm{~g} / \mathrm{L}$ & \\
\hline Sulfato de magnésio hepitahidratado & $1 \mathrm{~g} / \mathrm{L}$ & $0,5 \mathrm{~g} / \mathrm{L}$ & $1,5 \mathrm{~g} / \mathrm{L}$ & $0,5 \mathrm{~g} / \mathrm{L}$ & $2,5 \mathrm{~g} / \mathrm{L}$ & $1 \mathrm{~g} / \mathrm{L}$ \\
\hline Cloreto de sódio & $0,1 \mathrm{~g} / \mathrm{L}$ & & & & & \\
\hline Cloreto de cálcio dihidratado & $0,1 \mathrm{~g} / \mathrm{L}$ & $4,5 \mathrm{mg} / \mathrm{L}$ & $4,65 \mathrm{~g} / \mathrm{L}$ & $4,5 \mathrm{mg} / \mathrm{L}$ & $4,5 \mathrm{mg} / \mathrm{L}$ & \\
\hline Hidrogenofosfato de sódio & & & $2,5 \mathrm{~g} / \mathrm{L}$ & & & \\
\hline Glicose & $20 \mathrm{~g} / \mathrm{L}$ & $20 \mathrm{~g} / \mathrm{L}$ & $20 \mathrm{~g} / \mathrm{L}$ & $20 \mathrm{~g} / \mathrm{L}$ & $20 \mathrm{~g} / \mathrm{L}$ & $20 \mathrm{~g} / \mathrm{L}$ \\
\hline Biotina & $0,002 \mathrm{mg} / \mathrm{L}$ & $0,05 \mathrm{mg} / \mathrm{L}$ & $0,05 \mathrm{mg} / \mathrm{L}$ & $0,05 \mathrm{mg} / \mathrm{L}$ & $0,05 \mathrm{mg} / \mathrm{L}$ & \\
\hline Pantotenato de cálcio (Vit.B5) & $0,4 \mathrm{mg} / \mathrm{L}$ & $1 \mathrm{mg} / \mathrm{L}$ & $1 \mathrm{mg} / \mathrm{L}$ & $1 \mathrm{mg} / \mathrm{L}$ & $1 \mathrm{mg} / \mathrm{L}$ & \\
\hline Ácido fólico & $0,002 \mathrm{mg} / \mathrm{L}$ & & & & & \\
\hline Inositol & $2 \mathrm{mg} / \mathrm{L}$ & $25 \mathrm{mg} / \mathrm{L}$ & $25 \mathrm{mg} / \mathrm{L}$ & $25 \mathrm{mg} / \mathrm{L}$ & $25 \mathrm{mg} / \mathrm{L}$ & \\
\hline Niacina (vitamina B3) & $0,4 \mathrm{mg} / \mathrm{L}$ & $1 \mathrm{mg} / \mathrm{L}$ & $1 \mathrm{mg} / \mathrm{L}$ & $1 \mathrm{mg} / \mathrm{L}$ & $1 \mathrm{mg} / \mathrm{L}$ & \\
\hline Ácido p-aminobenzóico & $0,2 \mathrm{mg} / \mathrm{L}$ & $0,2 \mathrm{mg} / \mathrm{L}$ & $0,2 \mathrm{mg} / \mathrm{L}$ & $0,2 \mathrm{mg} / \mathrm{L}$ & $0,2 \mathrm{mg} / \mathrm{L}$ & \\
\hline Piridoxina (vitamina B6) & $0,4 \mathrm{mg} / \mathrm{L}$ & $1 \mathrm{mg} / \mathrm{L}$ & $1 \mathrm{mg} / \mathrm{L}$ & $1 \mathrm{mg} / \mathrm{L}$ & $1 \mathrm{mg} / \mathrm{L}$ & \\
\hline Riboflavina & $0,2 \mathrm{mg} / \mathrm{L}$ & & & & & \\
\hline Tiamina & $0,4 \mathrm{mg} / \mathrm{L}$ & $1 \mathrm{mg} / \mathrm{L}$ & $1 \mathrm{mg} / \mathrm{L}$ & $1 \mathrm{mg} / \mathrm{L}$ & $1 \mathrm{mg} / \mathrm{L}$ & $0,3 \mathrm{mg} / \mathrm{L}$ \\
\hline Ácido bórico & $0,5 \mathrm{mg} / \mathrm{L}$ & $1 \mathrm{mg} / \mathrm{L}$ & $1 \mathrm{mg} / \mathrm{L}$ & $1 \mathrm{mg} / \mathrm{L}$ & $1 \mathrm{mg} / \mathrm{L}$ & $0,5 \mathrm{mg} / \mathrm{L}$ \\
\hline Sulfato de cobre pentahidratado & $0,04 \mathrm{mg} / \mathrm{L}$ & & & & & $0,1 \mathrm{mg} / \mathrm{L}$ \\
\hline lodeto de potássio & $0,1 \mathrm{mg} / \mathrm{L}$ & $0,1 \mathrm{mg} / \mathrm{L}$ & $0,1 \mathrm{mg} / \mathrm{L}$ & $0,1 \mathrm{mg} / \mathrm{L}$ & $0,1 \mathrm{mg} / \mathrm{L}$ & $0,1 \mathrm{mg} / \mathrm{L}$ \\
\hline Cloreto férrico hexahidratado & $0,2 \mathrm{mg} / \mathrm{L}$ & $2,9 \mathrm{mg} / \mathrm{L}$ & $2,9 \mathrm{mg} / \mathrm{L}$ & $2,9 \mathrm{mg} / \mathrm{L}$ & $2,9 \mathrm{mg} / \mathrm{L}$ & $2 \mathrm{mg} / \mathrm{L}$ \\
\hline Sulfato de magnésio tetrahidratado & $0,4 \mathrm{mg} / \mathrm{L}$ & $0,87 \mathrm{mg} / \mathrm{L}$ & $0,87 \mathrm{mg} / \mathrm{L}$ & $0,87 \mathrm{mg} / \mathrm{L}$ & $0,87 \mathrm{mg} / \mathrm{L}$ & $0,4 \mathrm{mg} / \mathrm{L}$ \\
\hline Molibidato de sódio & $0,2 \mathrm{mg} / \mathrm{L}$ & $0,87 \mathrm{mg} / \mathrm{L}$ & $0,87 \mathrm{mg} / \mathrm{L}$ & $0,87 \mathrm{mg} / \mathrm{L}$ & $0,87 \mathrm{mg} / \mathrm{L}$ & $0,2 \mathrm{mg} / \mathrm{L}$ \\
\hline Cloreto de cobalto (II) & & $0,3 \mathrm{mg} / \mathrm{L}$ & $0,3 \mathrm{mg} / \mathrm{L}$ & $0,3 \mathrm{mg} / \mathrm{L}$ & $0,3 \mathrm{mg} / \mathrm{L}$ & $0,1 \mathrm{mg} / \mathrm{L}$ \\
\hline EDTA & & $15 \mathrm{mg} / \mathrm{L}$ & $15 \mathrm{mg} / \mathrm{L}$ & $15 \mathrm{mg} / \mathrm{L}$ & $15 \mathrm{mg} / \mathrm{L}$ & \\
\hline Sulfato de zinco hepitahidratado & $0,4 \mathrm{mg} / \mathrm{L}$ & $4,5 \mathrm{mg} / \mathrm{L}$ & $4,5 \mathrm{mg} / \mathrm{L}$ & $4,5 \mathrm{mg} / \mathrm{L}$ & $4,5 \mathrm{mg} / \mathrm{L}$ & \\
\hline Extrato de levedura & & & $0,5 \mathrm{~g} / \mathrm{L}$ & & & \\
\hline
\end{tabular}

* Composição dos meios após adequação segundo os reagentes disponíveis no laboratório. O meio de Papanikolaou não pode ser classificado como totalmente definido, pois contém extrato de levedura, que é um componente complexo. 
O meio YPD é um meio de cultivo complexo, composto por $20 \mathrm{~g} / \mathrm{L}$ de peptona (BD, New Jersey, EUA), $10 \mathrm{~g} / \mathrm{L}$ de extrato de levedura (BD, New Jersey, EUA) e 20 g/L de glicose (D-(+)-Glicose $\geq 99.5 \%$, GC, Sigma-Aldrich, St. Louis, EUA). Para preparo do meio YPD sólido foram acrescentados $15 \mathrm{~g} / \mathrm{L}$ de Agar (Sigma-Aldrich, St. Louis, EUA). O meio YPG possui a mesma composição do meio YPD com a substituição da fonte de carbono glicose por glicerol (for molecular biology, $\geq 99 \%$, Sigma, St. Louis, EUA) na mesma proporção de carbono (20,5 g/L), ou seja, meio YP acrescido de glicerol.

O meio denominado BARTH neste trabalho corresponde ao meio definido descrito por Barth \& Gaillardin (1996) com algumas modificações (Tabela 2). A substituição do fosfato de amônio monobásico $\left(\mathrm{NH}_{4} \mathrm{H}_{2} \mathrm{PO}_{4}\right)$ pelo sulfato de amônio $\left(\mathrm{NH}_{4}\right)_{2} \mathrm{SO}_{4}$ foi realizada, mantendo-se o equivalente em massa de nitrogênio; a solução de elementos traço foi modificada, mantendo-se a mesma quantidade dos elementos químicos principais e esse meio contém somente tiamina (Sigma-Aldrich, St. Louis, EUA) como fator de crescimento.

Todos os meios foram preparados com água Milli-Q (q.s.p.) e foram esterilizados em autoclave por vapor úmido $\left(121^{\circ} \mathrm{C}\right.$ por $\left.20 \mathrm{~min}\right)$. Reagentes termicamente instáveis (tiamina, ureia, sacarose e YNB) foram filtrados em membrana hidrofílica-PES estéril Millex-GP ${ }^{\circledR}$ de 0,22 m (Millipore, Massachusetts, EUA).

Tabela 2 - Meio descrito por Barth e Gaillardin (1996) e composição do meio usado neste trabalho, a partir de modificações do anterior.

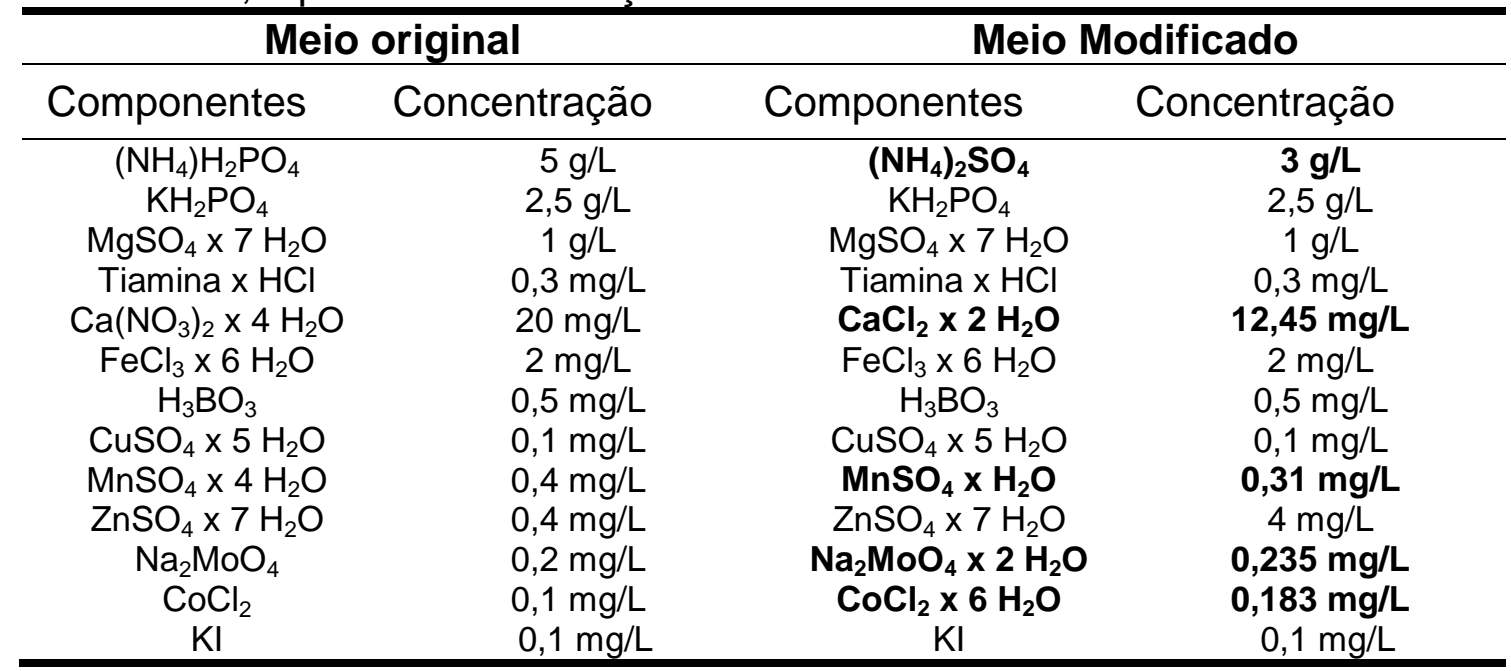




\subsection{CULTIVOS}

\subsubsection{Cultivos de $\underline{Y}$. lipolytica em frasco agitado}

\subsubsection{Cultivos para avaliação preliminar de meios de cultura}

Nestes ensaios foram utilizados os meios YPD, YNB, VERDUYN, PAPANIKOLAOU com e sem extrato de levedura, NICAUD, LUTTIK e BARTH (Tabelas 1 e 2).

O inóculo para cada cultivo foi obtido da seguinte maneira. A partir do estoque em tubo conservado a $-80{ }^{\circ} \mathrm{C}$, a linhagem Yarrowia lipolytica w29 foi estriada, usando-se a técnica da semeadura por esgotamento, em uma placa de Petri contendo meio YPD sólido. A placa foi então incubada em estufa a $30^{\circ} \mathrm{C}$ e após 48 h, com o auxílio de uma alça estéril, células de uma colônia isolada foram transferidas para um frasco Erlenmeyer de $500 \mathrm{~mL}$ contendo $100 \mathrm{~mL}$ de meio de cultura YPD. O frasco de inóculo foi mantido em incubador rotativo a $28{ }^{\circ} \mathrm{C}$ e 250 rpm overnight, período ao final do qual as células encontravam-se em fase exponencial de crescimento. Em seguida, o conteúdo do frasco foi centrifugado em centrífuga refrigerada (NT-825, Novatecnica, Piracicaba, Brasil), o sobrenadante descartado, as células ressuspendidas em meio de cultivo estéril (de composição idêntica à do meio em que as células seriam posteriormente cultivadas), a suspensão celular novamente centrifugada e as células novamente ressuspendidas em meio estéril de mesma composição. A absorbância a 600 nm (ABS(600)) da suspensão celular foi medida em espectrofotômetro (Genesys 20, Thermo Scientific, Waltham, EUA) e o volume de inóculo foi calculado de forma a se iniciar o cultivo com uma $\mathrm{ABS}(600)$ de 0,3 .

Os cultivos foram realizados em frasco de $500 \mathrm{~mL}$ com deflectores, para aumentar a transferência de oxigênio. Cada Erlenmeyer contendo $100 \mathrm{~mL}$ de meio de cultura e $20 \mathrm{~g} / \mathrm{L}$ iniciais de glicose como fonte de carbono foi mantido em incubador rotativo a $28{ }^{\circ} \mathrm{C}$ e $250 \mathrm{rpm}$ durante todo o período de amostragem.

Os cultivos duraram $10 \mathrm{~h}$, amostras foram retiradas tipicamente a cada hora e as seguintes determinações analíticas foram realizadas: $\mathrm{pH}$ em $\mathrm{pH}$-metro de 
bancada (AJX-512, Micronal SSA, Brasil), densidade óptica por espectrofotometria (Genesys 20, Thermo Scientific, Waltham, EUA), inspeção da pureza da cultura por microscopia óptica, concentrações de metabólitos extracelulares por cromatografia líquida de alta eficiência (HPLC). Este procedimento foi realizado até a saída das células da fase exponencial de crescimento, que foi constatada através das medidas da ABS(600) ao longo do tempo.

\subsubsection{Crescimento de Y. lipolytica em diferentes fontes de carbono}

Este ensaio foi realizado em meio VERDUYN, em meio BARTH e em meio BARTH com acréscimo de $1 \mathrm{~mL} / \mathrm{L}$ de uma solução de vitaminas composta por Dbiotina $0,05 \mathrm{~g} / \mathrm{L}$, pantotenato de cálcio $1,0 \mathrm{~g} / \mathrm{L}$, ácido nicotínico $1,0 \mathrm{~g} / \mathrm{L}$, mio-inositol 25,0 g/L, hidrocloreto de tiamina 1,0 g/L, hidrocloreto de piridoxol 1,0 g/L e ácido 4aminobenzóico 0,2 g/L. As fontes de carbono estudadas foram glicose, sacarose, xilose ou glicerol, na concentração inicial de $20 \mathrm{~g} / \mathrm{L}$.

Os inóculos para estes cultivos foram obtidos da seguinte maneira. A partir do estoque em tubo conservado a $-80{ }^{\circ} \mathrm{C}$, as linhagens foram estriadas, usando a técnica da semeadura por esgotamento, em placa de Petri contendo meio YPD sólido. As placas foram então incubadas em estufa a $30{ }^{\circ} \mathrm{C}$. Após $48 \mathrm{~h}$, com o auxilio de uma alça estéril, células de uma colônia isolada foram transferidas para um frasco Erlenmeyer de $500 \mathrm{~mL}$ com deflectores, contendo $100 \mathrm{~mL}$ de meio de cultura BARTH com $20 \mathrm{~g} / \mathrm{L}$ de glicose como fonte de carbono. Os frascos foram incubados a $28{ }^{\circ} \mathrm{C}$ e $250 \mathrm{rpm}$, após $24 \mathrm{~h}$ foi adicionado $10 \mathrm{~g} / \mathrm{L}$ de glicose nos frascos e novamente incubados por mais $12 \mathrm{~h}$ nas mesmas condições, obtendo assim um inóculo em meio definido com alta concentração celular.

O inóculo foi então centrifugado, lavado e resuspenso em meio BARTH sem fonte de carbono. A ABS(600) da suspensão celular foi medida e o volume de inóculo foi calculado de forma a se iniciar o cultivo com uma $A B S(600)$ de 0,1 . Os cultivos foram realizados em frasco Erlenmeyer de $500 \mathrm{~mL}$ com deflectores, contendo $100 \mathrm{~mL}$ de meio de cultura descrito acima, os frascos foram mantidos sob agitação a 250 rpm, $28 \stackrel{\circ}{\circ}$ por 72 horas e em seguida foi medida a ABS(600). 
4.3.1.3 Cinéticas de crescimento de Y. lipolytica em glicose e glicerol

Estes ensaios foram realizados em meio BARTH e para cada cinética realizada, com glicose ou glicerol como fonte de carbono, foi realizada em paralelo uma cinética em meio YPD ou YPG, respectivamente. Em todos os cultivos, independentemente da fonte de carbono utilizada, empregou-se a mesma quantidade inicial de carbono.

Os inóculos para estes cultivos foram obtidos da seguinte maneira. A partir do estoque em tubo conservado a $-80{ }^{\circ} \mathrm{C}$, as linhagens foram estriadas, usando a técnica da semeadura por esgotamento, em placa de Petri contendo meio YPD sólido. As placas foram então incubadas em estufa a $30^{\circ} \mathrm{C}$. Após $48 \mathrm{~h}$, com o auxílio de uma alça estéril, células de uma colônia isolada foram transferidas para um frasco Erlenmeyer de $500 \mathrm{~mL}$ com deflectores, contendo $100 \mathrm{~mL}$ de meio de cultura BARTH com $20 \mathrm{~g} / \mathrm{L}$ de glicose como fonte de carbono. Os frascos foram incubados a $28{ }^{\circ} \mathrm{C}$ e $250 \mathrm{rpm}$, após $24 \mathrm{~h}$ foi adicionado $10 \mathrm{~g} / \mathrm{L}$ de glicose nos frascos e novamente incubados por mais $12 \mathrm{~h}$ nas mesmas condições, obtendo assim um inóculo em meio definido com alta concentração celular.

O inóculo foi então centrifugado, lavado e ressuspenso com o meio Barth. A ABS(600) da suspensão celular foi medida e o volume de inóculo foi calculado de forma a se iniciar o cultivo com uma $A B S(600)$ de 0,3. Os cultivos foram realizados em frasco Erlenmeyer de $500 \mathrm{~mL}$ com deflectores, contendo $100 \mathrm{~mL}$ de meio Barth. Os cultivos foram realizados em Erlenmeyers de $500 \mathrm{~mL}$ com deflectores, para aumentar a transferência de oxigênio. Cada Erlenmeyer contendo $100 \mathrm{~mL}$ de meio de cultura e $20 \mathrm{~g} / \mathrm{L}$ iniciais de glicose ou 20,5 g/L iniciais de glicerol, como fonte de carbono, foi mantido em incubador rotativo a $28{ }^{\circ} \mathrm{C}$ e $250 \mathrm{rpm}$ durante todo o período de amostragem.

Amostras foram retiradas tipicamente a cada $2 \mathrm{~h}$ durante 20 horas de cultivo e uma amostra foi retirada no final do experimento com $32 \mathrm{~h}$ de cultivo. As seguintes determinações analíticas foram realizadas após cada amostragem: $\mathrm{pH}$ em pH-metro de bancada (AJX-512, Micronal SSA, Brasil), densidade óptica por espectrofotometria (Genesys 20, Thermo Scientific, Waltham, EUA), inspeção da pureza da cultura por microscopia óptica, concentrações de metabólitos extracelulares por cromatografia líquida de alta eficiência (HPLC). 
4.3.1.4. Cultivos para análise de partículas lipídicas

Estes cultivos foram realizados no laboratório da Prof ${ }^{a}$. Monica Montero Lomeli, na Universidade Federal do Rio de Janeiro (UFRJ), com o intuito de aprendizagem das técnicas de fixação e coloração de partículas lipídicas de leveduras.

Foram utilizadas nos cultivos as seguintes leveduras: Saccharomyces cerevisiae BY 4741 e Yarrowia lipolytica IMUFRJ 50682. Ambas foram preservadas de acordo com a metodologia descrita no item 4.1.

Transferiu-se uma colônia isolada em uma placa com meio YPD sólido, com o auxilio de uma alça estéril, para um tubo Falcon de $50 \mathrm{~mL}$ contendo $5 \mathrm{~mL}$ de meio YPD. O tubo foi incubado por $48 \mathrm{~h}$ a $28{ }^{\circ} \mathrm{C}$ e $250 \mathrm{rpm}$. Posteriormente, o inóculo foi transferido para o meio de cultivo segundo metodologia descrita no item 4.3.1. Os cultivos foram iniciados com uma $A B S(600)$ de 0,3 em um frasco de $250 \mathrm{~mL}$ contendo $60 \mathrm{~mL}$ de meio de cultura. A levedura Y. lipolytica IMUFRJ 50682 foi cultivada nos meios YPD e YNB (ambos esterilizados em autoclave), e a levedura $S$. cerevisiae BY 4741 foi cultivada somente em meio YPD.

O cultivo foi realizado a $28{ }^{\circ} \mathrm{C}$ e $250 \mathrm{rpm}$, foram retiradas amostras a cada 2 horas e foi medida a absorbância por espectrofotometria ABS(600). Além disto, alíquotas foram retiradas, fixadas com formaldeído e posteriormente analisadas por microscopia e fluorimetria (itens 4.4.3. e 4.4.4).

As fixação das células com formaldeído consistiu em primeiramente acrescentar formaldeído 37\% (Sigma-Aldrich) na quantidade de 1/9 do volume da amostra. Em seguida, a amostra foi mantida em repouso por 10 minutos e posteriormente centrifugada a $5000 \mathrm{rpm}$ (Força $\mathrm{G}=3250$ ) por 5 minutos. $O$ sobrenadante foi descartado e acrescentou-se $1 \mathrm{~mL}$ de água destilada. As células foram ressuspendidas e novamente foram centrifugadas, descartando-se em seguida o sobrenadante. As células fixadas foram armazenadas a $10{ }^{\circ} \mathrm{C}$, por no máximo $72 \mathrm{~h}$, para posteriores análises. 
4.3.1.5 Cultivo para análise elementar da biomassa de Y. lipolytica

O inóculo foi obtido conforme descrito no item 4.3.1.3. Foi realizada uma cinética de crescimento em meio BARTH com $10 \mathrm{~g} / \mathrm{L}$ de glicose e 1,5 g/L de fonte de nitrogênio sulfato de amônio iniciais, usando a linhagem Y. lipolytica w29.

O cultivo foi realizado em Erlenmeyer de $500 \mathrm{~mL}$ com deflectores, contendo $100 \mathrm{~mL}$ de meio de cultura, com uma $\mathrm{ABS}(600)$ inicial de 0,2 e mantido em incubador rotativo a $28{ }^{\circ} \mathrm{C}$ e $250 \mathrm{rpm}$.

Foi retirada uma amostra no final do cultivo, que ocorreu antes das células saírem da fase exponencial de crescimento, ou seja, sem ter ocorrido limitação nutricional.

A amostra foi centrifugada, lavada com água destilada estéril, novamente centrifugada e congelada. Posteriormente a amostra foi liofilizada e encaminhada para análise elementar da biomassa, na Central Analítica do Instituto de Química da USP (item 4.4.6).

\subsubsection{Cultivos de Y. lipolytica em biorreator}

\subsubsection{Inóculo}

O inóculo para os cultivos em reator foi obtido da seguinte maneira: o conteúdo de um tubo do estoque contendo as linhagens, conservado a $-80{ }^{\circ} \mathrm{C}$ (item 4.1), foi transferido para um frasco Erlenmeyer de $500 \mathrm{~mL}$ contendo $100 \mathrm{~mL}$ de meio de cultura YPD e mantido a $28{ }^{\circ} \mathrm{C}$ e $250 \mathrm{rpm}$ por $8 \mathrm{~h}$. Posteriormente, um volume de 40 $\mathrm{mL}$ desse pré-inóculo foi centrifugado, resuspenso em $10 \mathrm{~mL}$ de água destilada estéril e uma alíquota de $1 \mathrm{~mL}$ dessa suspensão foi transferida para um frasco Erlenmeyer de $500 \mathrm{~mL}$, com deflectores, contendo $100 \mathrm{~mL}$ de meio de cultura BARTH com a fonte de carbono em que, posteriormente, seria realizado o cultivo. $O$ frasco de inóculo foi mantido em incubador rotativo a $28{ }^{\circ} \mathrm{C}$ e $250 \mathrm{rpm}$ "overnight".

O inóculo foi então centrifugado, lavado e resuspenso com o meio em que posteriormente seria cultivado. A $A B S(600)$ da suspensão celular foi medida e o 
volume de inóculo foi calculado de forma a se iniciar o cultivo com uma ABS(600) de 0,2 .

\subsubsection{Cultivo em batelada}

O inóculo foi obtido conforme descrito acima (item 4.3.1.3) e o volume de inóculo a ser transferido para o biorreator foi calculado de forma a se iniciar o cultivo com uma $A B S(600)$ de 0,2. Os cultivos foram realizados em um biorreator de bancada (marca New Brunswick Scientific, modelo BIOFLO III, Edison, New Jersey, EUA) com volume útil de 1 litro, um impelidor com seis pás planas tipo Rushton e não foram usadas chicanas.

Os cultivos foram realizados em meio BARTH (item 4.2) acrescido de 0,3 mL/L de anti-espumante (Antifoam-C, Sigma-Aldrich, St. Louis, EUA) nas seguintes condições: temperatura constante de $28{ }^{\circ} \mathrm{C}$, agitação constante de 1000 rpm, vazão de ar de 1 L.min ${ }^{-1}$ (1 vvm), o pH foi mantido em 5,0 com a adição controlada de uma solução de hidróxido de potássio $2 \mathrm{~mol} / \mathrm{L}$. Foram armazenados dados de temperatura, $\mathrm{pH}$, agitação, oxigênio dissolvido, $\mathrm{CO}_{2}$ e $\mathrm{O}_{2}$ no gás de saída, a cada minuto, através do software BioCommand Plus (New Brunswick Scientific).

O crescimento celular foi acompanhado pela retirada de amostras da cultura em tempos pré-determinados. Nestas amostras foram realizadas as seguintes determinações analíticas: medida da $\operatorname{ABS}(600)$ e da massa seca de células, como descrito no item 4.4.1, determinação do $\mathrm{pH}$, inspeção da pureza da cultura por microscopia óptica e determinação das concentrações de metabólitos extracelulares por HPLC (item 4.4.2). Os cultivos eram conduzidos até o início da queda do sinal da fração molar de $\mathrm{CO}_{2}$ no gás de saída do biorreator, que ocorre com o esgotamento da fonte de carbono.

\subsubsection{Cultivo em quimiostato}

O inóculo foi obtido conforme descrito acima (item 4.3.2.1) e o volume de inóculo a ser transferido para o biorreator foi calculado de forma a se iniciar o cultivo com uma $A B S(600)$ de 0,1 . Os cultivos em quimiostato foram realizados com a 
linhagem de Yarrowia lipolytica IMUFRJ 50682, nas vazões específicas 0,15 e 0,25 $\mathrm{h}^{-1}$, em um biorreator de bancada (marca New Brunswick Scientific, modelo BIOFLO III, Edison, New Jersey, EUA) com volume útil de 1 litro, foi utilizado um impelidor com 6 pás planas tipo Rushton e não foram usadas chicanas. Um esquema geral do sistema utilizado é apresentado na Figura 8.

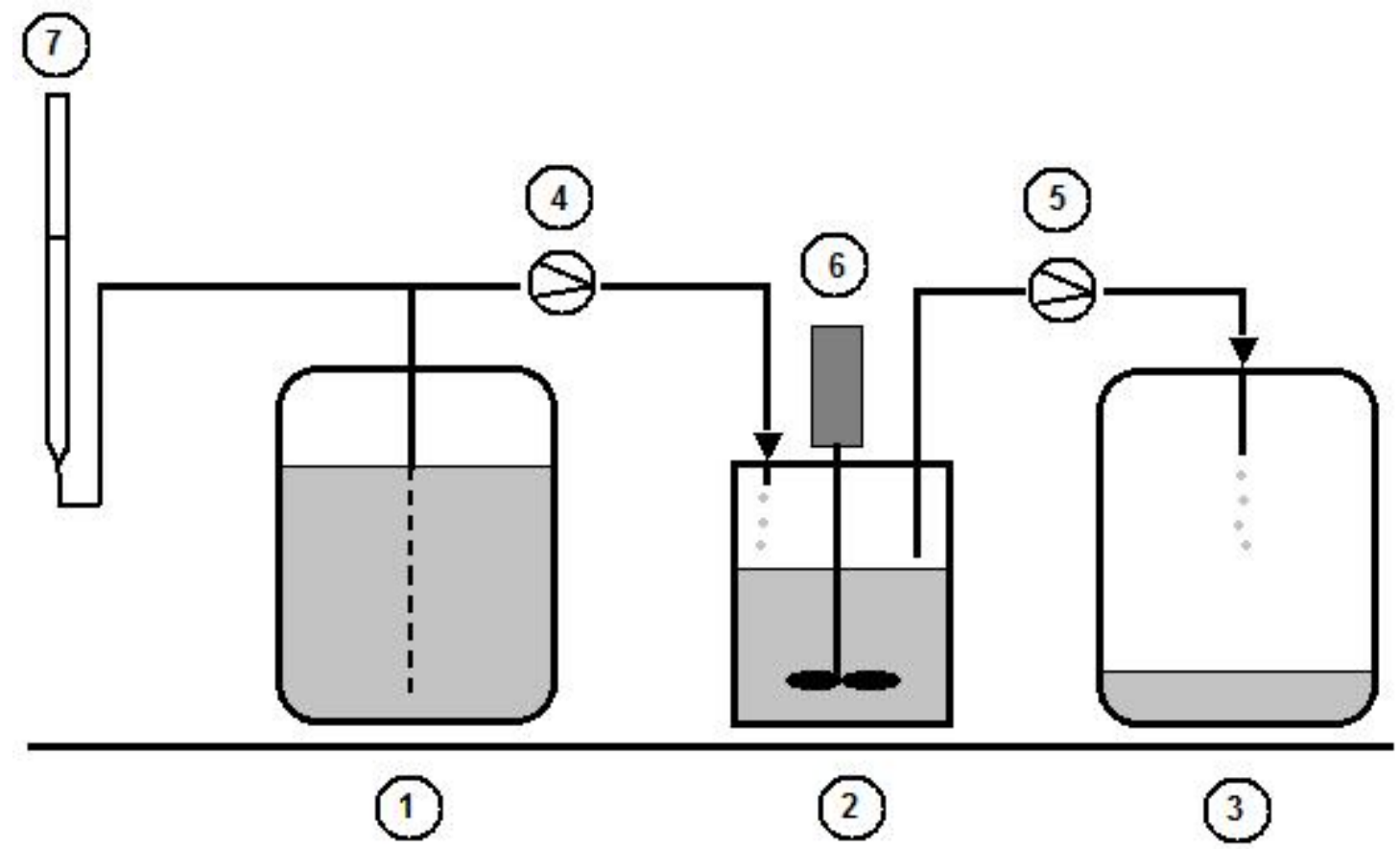

Figura 8 - Configuração geral do sistema de biorreatores empregado nos cultivos contínuos. 1) Frasco contendo meio de alimentação; 2) Biorreator de bancada; 3) Frasco para coleta do efluente; 4) Bomba peristáltica de alimentação de meio; 5) Bomba peristáltica de retirada de efluente (meio e células); 6) Sistema de agitação; 7) Sistema de medida da vazão de alimentação. Fonte: Basso, T. O. (2011).

Os cultivos foram realizados em meio BARTH (item 4.2) acrescido de $0,3 \mathrm{~mL} / \mathrm{L}$ de anti-espumante, contendo glicerol $20,5 \mathrm{~g} / \mathrm{L}$ como única fonte de carbono e com sulfato de amônio como fonte de nitrogênio, presente na concentração de 0,3 g/L. Nestas condições, os cultivos seriam realizados sob limitação de nitrogênio.

As condições do cultivo foram as seguintes: temperatura constante de $28{ }^{\circ} \mathrm{C}$, agitação constante de $1000 \mathrm{rpm}$, injeção de ar comprimido a uma vazão de 0,5 L. $\min ^{-1}$ (0,5 vvm), pH mantido em 5,0 com a adição controlada de uma solução de hidróxido de potássio $2 \mathrm{~mol} / \mathrm{L}$. A concentração de oxigênio dissolvido foi monitorada de forma contínua por um eletrodo de oxigênio dissolvido (marca Mettler-Toledo, Columbus, $\mathrm{OH}, \mathrm{USA}$ ). Foram armazenados dados de temperatura, pH, agitação, 
oxigênio dissolvido, $\mathrm{CO}_{2}$ e $\mathrm{O}_{2}$ no gás de saída, a cada minuto, através do software BioCommand Plus (New Brunswick Scientific).

Para o regime em quimiostato, que foi iniciado como um cultivo descontínuo, a adição e retirada contínuas de meio passaram a ocorrer no momento da exaustão da fonte de nitrogênio na etapa batelada, o que correspondeu ao início da queda do sinal de $\mathrm{CO}_{2}$ no gás de saída do reator. A adição de meio de cultura estéril ao biorreator foi realizada por meio de uma bomba peristáltica de precisão (marca Watson-Marlow, modelo 101U/R, Falmouth, Cornwall TR11 4RU, Inglaterra). A remoção de meio foi realizada através de uma bomba continuamente ligada e conectada a um dreno localizado a uma altura adequada no biorreator, de forma a manter um volume de trabalho contínuo igual a $1 \mathrm{~L}$.

O estado estacionário foi definido da seguinte forma. Após decorridos no mínimo três tempos de residência desde a última mudança nas condições de cultivo, os valores da concentração celular e da fração molar de $\mathrm{CO}_{2}$ no gás de saída do biorreator deveriam apresentar variação menor que $2 \%$ em duas amostras retiradas dentro dos dois tempos de residência subsequentes aos três tempos de residência mencionados acima. Para $D$ de $0,15 \mathrm{~h}^{-1}$ um tempo de residência equivale à 6:42 $\mathrm{h}$ e $D$ igual a $0,25 \mathrm{~h}^{-1}$, um tempo de residência de à $4 \mathrm{~h}$.

Constatado o estado estacionário, após decorrer um tempo de residência, foi realizada a amostragem para análise residual de substrato limitante. Essa coleta consistiu em amostrar com uma seringa $20 \mathrm{~mL}$ contendo em seu interior esferas de aço inoxidável (62 g, $4 \mathrm{~mm}$ de diâmetro) previamente resfriadas a $-18{ }^{\circ} \mathrm{C}$. A amostra foi imediatamente filtrada por pressão positiva em filtros de porosidade 0,22 $\mathrm{m}$ e congelada para posterior análise (item 4.4.2). Essa metodologia é descrita por Mashego et al. (2003) e permite o rápido resfriamento da amostra, o que impede que a pequena quantidade de substrato limitante existente na amostra seja consumida durante a amostragem. Logo em seguida foi realizada a amostragem para a análise da ABS(600), massa seca de células, pH, pureza da cultura, HPLC (item 4.4.2), análise elementar da biomassa celular (item 4.4.6) e análise de partículas lipídicas por microscopia (item 4.4.4). 


\subsection{DETERMINAÇÕES ANALÍTICAS}

\subsubsection{Quantificação da concentração celular}

Nos cultivos em frasco agitado, a concentração celular foi medida indiretamente pela medida da $\operatorname{ABS}(600)$ em espectrofotômetro (marca Thermo Scientific, modelo Genesys 20, West Palm Beach, FL, EUA) e posteriormente correlacionada com a massa seca de células, essa correlação celular será expressa em gramas de massa seca (g DW, do inglês dry weight) por litro. Essa correlação entre absorbância e massa seca foi obtida através de uma curva de calibração realizada com os dados das cinéticas de crescimento em biorreator (item 5.6). Nos cultivos em biorreator, a concentração celular foi também determinada em termos de massa seca de células, conforme descrito por Olsson e Nielsen (1997).

\subsubsection{Quantificação da concentração de metabólitos extracelulares}

A quantificação das concentrações de metabólitos extracelulares foi realizada por cromatografia líquida de alta eficiência (HPLC) em equipamento marca Shimadzu, modelo UFLC CBM-20 $0^{\underline{a}}$ (Japão), usando os padrões glicose, ácido succinico, ácido láctico, glicerol, ácido acético e etanol, como apresentado no cromatograma no Apêndice B desse trabalho. Estes compostos foram separados por uma coluna de exclusão iônica (marca Biorad, modelo Aminex HPX-87H, EUA) a 60 ${ }^{\circ} \mathrm{C}$ com uma vazão de $0,6 \mathrm{~mL} / \mathrm{min}$ de uma solução de $\mathrm{H}_{2} \mathrm{SO}_{4}(2 \mathrm{mmol} / \mathrm{L})$ como fase móvel. A detecção foi feita por índice de refração, usando equipamento modelo RID$10 A$ (marca Shimadzu, Japão).

A quantificação da concentração residual do substrato limitante foi realizada por kit de quantificação de amônia pelo método UV (Ammonia UV-Test Enzymatic Bioanalysis, Boehinger Mannheim), após um tratamento recomendado pelo fabricante que consistiu em deixar as amostras em banho termostático a $80{ }^{\circ} \mathrm{C}$ por 15 minutos para desnaturar proteínas que poderiam interferir na análise e também concentrar as amostras de 3000 para $250 \mu \mathrm{L}$ (ou seja, em 12 vezes), em um 
concentrador a vácuo, com a finalidade de obter uma concentração de amônia dentro da faixa de detecção do kit.

\subsubsection{Análise de fluorescência por fluorimetria}

As análises de fluorescência foram realizadas segundo metodologia desenvolvida por Bozaquel-Morais (2010), nas amostras previamente fixadas, e a leitura foi realizada com excitação em 485 nm e emissão em 510 nm em um fluorômetro (Molecular Devices SpectraMax M5, Molecular Devices, CA, EUA).

Os dados obtidos por fluorimetria foram analisados através do gráfico da concentração de células contra a fluorescência medida, a inclinação da reta representa a quantidade de fluorescência recuperada por unidade de concentração de células.

\subsubsection{Análise de PLs por microscopia de fluorescência}

A análise de partículas lipídicas por microscopia de fluorescência foi realizada utilizando a sonda fluorescente BODIPY 493/503 (Molecular Probes). Foram utilizados $2 \mu \mathrm{L}$ da amostra e 0,5 $\mu \mathrm{L}$ da solução de corante $(1,25 \mu \mathrm{g}$ de BODIPY 493/503/mL). Foram tiradas fotografias para posterior análise de imagem através do microscópio Leica DMLS (Leica Microsystems, Rijswijk, Holanda), com câmera digital Leica modelo DFC 300FX (Leica Microsystems, Rijswijk, Holanda) e o Software Leica QWin Image Processing e Analysis V. 2.3 (Desenvolvido por Leica Microsystems Imaging Solutions, Holanda).

Os dados obtidos por microscopia foram analisados pelo software FreeWare ImageJ (desenvolvido por National Institutes of Health, EUA) e pelo Software Leica QWin Image Processing \& Analysis V. 2.3.

4.4.5 Determinação da fração molar de $\mathrm{O}_{2}$ e $\mathrm{CO}_{2}$ no gás de saída do biorreator 
Os gases de saída do biorreator foram previamente secos pela passagem em recipiente com sílica, e analisados quanto às frações molares de $\mathrm{O}_{2}$ e $\mathrm{CO}_{2}$ por um analisador de gases.

A determinação da fração molar de $\mathrm{O}_{2}$ no gás de saída foi realizada por um sensor de gás $\mathrm{O}_{2}$ 0-25\% 6mm HC (Hose barbed Connection), marca Applikon Biotechnology, EUA. Este tipo de sensor é baseado no princípio de uma célula bombeadora de oxigênio e por isso independente de gases de referência. $A$ análise de oxigênio no fluxo de gases de escape é feita através da medida da corrente na célula que é proporcional à concentração de oxigênio.

A determinação da fração molar de $\mathrm{CO}_{2}$ no gás de saída foi realizada por um sensor de gás $\mathrm{CO}_{2}$ 0-10\% 6mm HC, marca Applikon Biotechnology, EUA. O princípio da medição é espectrofotométrico por medição da absorção de luz infravermelha em dois comprimentos de onda que mede a porcentagem de $\mathrm{CO}_{2}$ no fluxo de gases.

\subsubsection{Análise elementar da biomassa de $\underline{Y . \text { lipolytica }}$}

A análise elementar foi realizada no Instituto de Química da USP a partir de uma amostra liofilizada. A amostra de biomassa seca foi obtida por lavagem do meio de cultura, centrifugação e posterior liofilização. A quantidade de carbono, nitrogênio e hidrogênio foram determinados usando um Analisador elementar CHN (Perkin Elmer, EUA). Resumindo, a amostra foi primeiramente pesada usando uma balança digital com 6 dígitos decimais e então introduzida no equipamento, onde ocorre a combustão na presença de oxigênio puro. Desta forma, todo o carbono da amostra é convertido a $\mathrm{CO}_{2}$, o hidrogênio em $\mathrm{H}_{2} \mathrm{O}$ e o nitrogênio em vários óxidos $\left(\mathrm{N}_{\mathrm{X}} \mathrm{O}_{\mathrm{X}}\right)$. Posteriormente em uma coluna com $\mathrm{Cu}^{0}$ os óxidos de nitrogênio são forçados a reduzir $\mathrm{N}_{2}$. Os gases $\mathrm{CO}_{2}, \mathrm{H}_{2} \mathrm{O}$ e $\mathrm{N}_{2}$ são arrastados pelo gás He, separados por uma coluna cromatográfica e detectados por um detector de condutividade térmica (TCD).

Um teor de cinzas de $7 \%$ da biomassa de levedura foi considerado, com base no valor médio encontrado para células de leveduras (Nilsen e Villadsen, 1994). O teor de oxigênio foi calculado subtraindo-se o $\mathrm{C}, \mathrm{H}, \mathrm{N}$, e cinzas do total. 


\subsection{CÁLCULO DE PARÂMETROS FISIOLÓGICOS}

Os parâmetros fisiológicos (fator de conversão substrato a célula, velocidade específica de crescimento celular, taxa de consumo de oxigênio, taxa de produção de $\mathrm{CO}_{2}$, etc.) dos cultivos realizados foram calculados segundo Schimidell et al. (2001).

Para o cálculo das velocidades máximas específicas de crescimento ( máx $\left[h^{-1}\right]$ ), gerou-se um gráfico do logaritmo neperiano dos valores de ABS(600) (ordenada) versus o tempo (abcissa). Aplicando regressão linear no trecho equivalente ao crescimento exponencial, o valor do coeficiente angular desta curva, representa o valor de máx em $\left[\mathrm{h}^{-1}\right]$. Foram considerados os valores que apresentavam melhor $\mathrm{R}^{2}$ na regressão linear e os resultados obtidos foram testados através da análise de variância pelo Software Excel 2010 (Microsoft, EUA) para analisar as possíveis diferenças entre os tratamentos.

Para obtenção do fator de conversão de substrato a biomassa $\left(Y_{x / s}\right)$ da fase exponencial de crescimento, foi gerado um gráfico com os valores de concentração celular em massa seca ( $\mathrm{g}$ DW. $\mathrm{L}^{-1}$ ), na ordenada, em função dos valores de concentração de substrato ([g S.L ${ }^{-1}$ ), na abcissa. $O$ valor do módulo do coeficiente angular, obtido pela regressão linear dos dados em fase exponencial equivale ao $Y_{x / s}$ $\left.(g D W) \cdot(g S)^{-1}\right)$.

A taxa de consumo de oxigênio ( $\left(\mathrm{q}_{\mathrm{O} 2}\right)$ e a taxa de produção de $\mathrm{CO}_{2}\left(\mathrm{q}_{\mathrm{co} 2}\right)$ foram calculadas pelo emprego do balance gasoso, equação 2 e 3, através dos dados de $\mathrm{O}_{2}$ e $\mathrm{CO}_{2}$ quantificados no gás de saída do reator.

$$
\begin{aligned}
& \mathrm{q}_{\mathrm{O} 2}=1 / \mathrm{X} \cdot 1 / \mathrm{V} \cdot\left(\mathrm{ge} \cdot \mathrm{X}_{\mathrm{O} 2 \mathrm{e}}-\mathrm{gs} \cdot \mathrm{X}_{\mathrm{O} 2 \mathrm{~s}}\right) \\
& \mathrm{q}_{\mathrm{CO} 2}=1 / \mathrm{X} \cdot 1 / \mathrm{V} \cdot\left(\mathrm{gs} \cdot \mathrm{X}_{\mathrm{CO} 2 \mathrm{~s}}{ }^{-} \text {ge } \cdot \mathrm{X}_{\mathrm{CO} 2 \mathrm{e}}\right) \\
& \text { gs }- \text { fluxo molar do gás de saída }(\mathrm{mol} / \mathrm{h}) \\
& \text { ge }- \text { fluxo molar do gás de entrada }(\mathrm{mol} / \mathrm{h}) \\
& X-\text { concentração celular g } \mathrm{DW} / \mathrm{L} \\
& V-\text { volume de liquido no reator } \mathrm{L}
\end{aligned}
$$

O coeficiente respiratório foi calculado a partir da razão entre a taxa de consumo de oxigênio e a taxa de produção de $\mathrm{CO}_{2}\left(\mathrm{q}_{\mathrm{co} 2} / \mathrm{q}_{2}\right)$. 
A taxa específica de consumo do substrato ( $q_{s}$ [g $S /(g$ DW.h)]), na fase exponencial de crescimento, foi calculada através da razão entre a velocidade específica de crescimento $\left(\mu\left[\mathrm{h}^{-1}\right]\right)$ e o fator de conversão substrato a célula $\left(\mathrm{Y}_{\mathrm{x} / \mathrm{s}}[(\mathrm{g}\right.$ $\left.\left.\mathrm{DW}) \cdot(\mathrm{g} \mathrm{S})^{-1}\right]\right)$.

A constante de saturação $\left(K_{s}[\mathrm{mg} / \mathrm{L}]\right)$ foi calculada a partir da equação 4 , proposta por Monod (1949) e empregada para explicar a relação entre a concentração do substrato limitante no meio, com a velocidade especifica de crescimento do microrganismo.

$\boldsymbol{\mu}=\frac{\mu_{\max } \cdot S}{K_{\mathrm{s}}+S}$

$\mathrm{S}$ - substrato limitante $(\mathrm{mg} / \mathrm{L})$

- velocidade específica de crescimento microbiano $\left(\mathrm{h}^{-1}\right)$

máx - velocidade específica máxima de crescimento microbiano $\left(\mathrm{h}^{-1}\right)$

$\mathrm{K}_{\mathrm{s}}$ - constante de saturação (mg/L)

A taxa de manutenção $\left(m_{s}\right)$ e o fator de conversão substrato a célula verdadeiro ( $\left.\mathrm{Y}_{\mathrm{x} / \mathrm{s} \text { true }}\right)$ foi determinado, segundo Pirt (1965), através da geração de um gráfico com valores da taxa específica de consumo de energia ( $q_{s}$ [mg $\left.S /(m g ~ D W . h)\right]$ ) na ordenada e a taxa de diluição ( $D\left[h^{-1}\right]$ ) na abcissa. Aplicando regressão linear, a razão de 1 sobre o coeficiente angular desta curva é igual ao $\mathrm{Y}_{\mathrm{x} / \mathrm{s} \text { true }} \mathrm{e}$ o coeficiente linear é igual a ms, como mostrado na equação 5.

$\boldsymbol{q}_{s}=\frac{1}{\boldsymbol{Y}_{X / S}^{\text {true }}} \cdot \boldsymbol{\mu}+\boldsymbol{m}_{s}$

$\mathrm{q}_{\mathrm{s}}$ - taxa específica de consumo de energia (mg S /(mg DW.h))

$Y_{X / S}^{\text {true }}$ - fator de conversão substrato a célula verdadeiro (g DW/g S)

$\mu$ - velocidade específica de crescimento $\left(h^{-1}\right)$

$\mathrm{m}_{\mathrm{s}}$ - taxa de manutenção celular (mg S/(mg DW.h)) 


\subsection{EXPERIMENTOS REALIZADOS}

Abaixo, na Figura 9 é apresentada a sequência de experimentos realizados durante este projeto de mestrado.

\section{CULTIVOS EM FRASCO AGITADO}

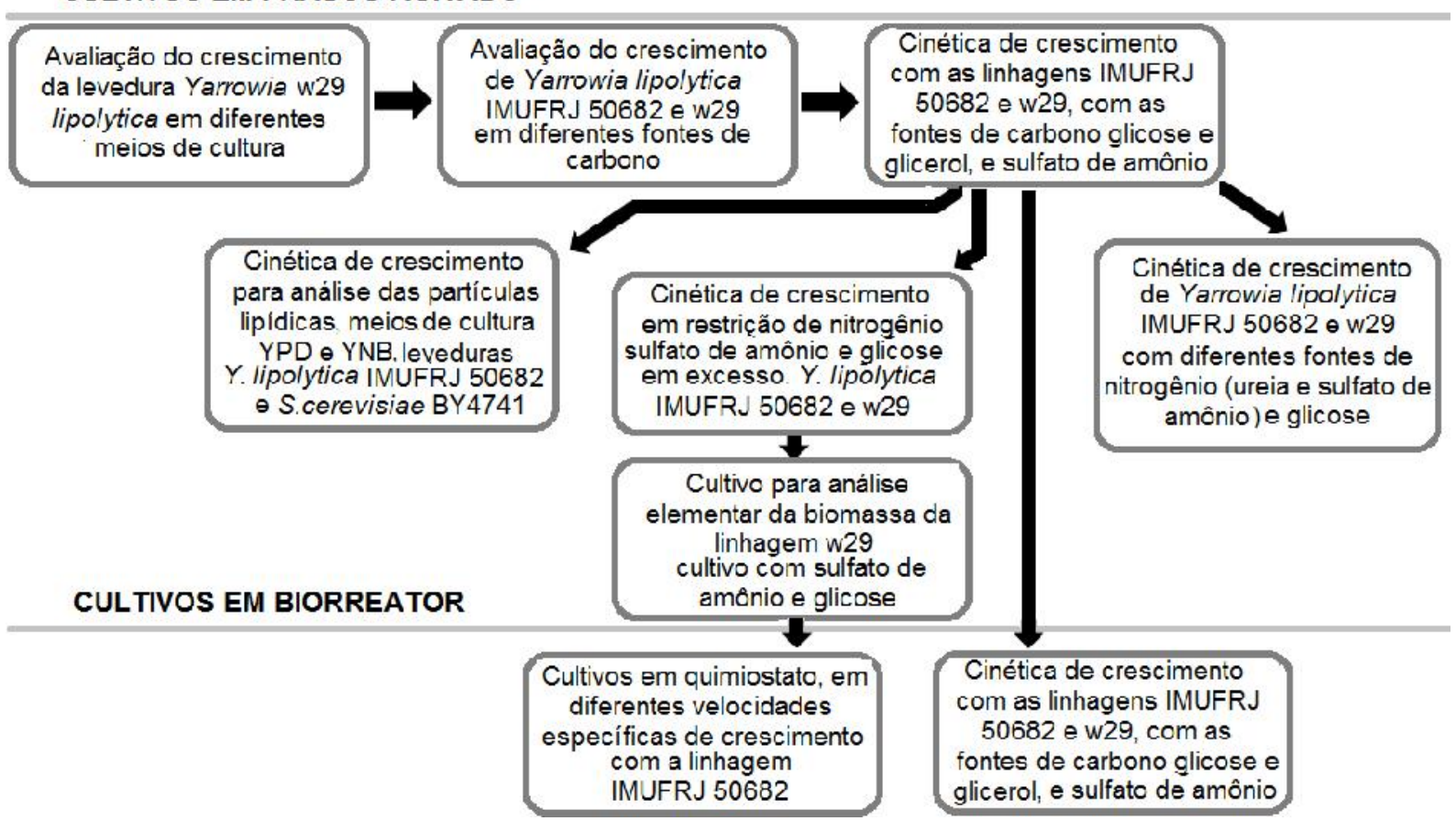

Figura 9 - Fluxograma dos experimentos realizados durante o mestrado.

\section{RESULTADOS E DISCUSSÃO}

\subsection{AVALIAÇÃO DE MEIOS DE CULTURA DEFINIDOS ADEQUADOS AO CRESCIMENTO DE Yarrowia lipolytica}

No estudo da fisiologia microbiana, deve ser dada preferência à utilização de meios de cultura de composição totalmente definida, pois somente estes permitem a avaliação do efeito individual de componentes do meio. Por exemplo, torna-se possível avaliar se uma determinada molécula pode servir de fonte única de carbono e energia ou se uma determinada fonte de nitrogênio pode ser usada como única fonte de nitrogênio pelas células. Além disto, através do uso de meios definidos e de 
análises apropriadas pode-se, por exemplo, aplicar um balanço de carbono a uma determinada situação, de forma a verificar quais são os principais produtos metabólicos das células e/ou se ocorre algum erro grosseiro nas determinações analíticas (Zhang e Greasham,1999). Finalmente, os meios definidos permitem comparar parâmetros fisiológicos do microrganismo como, por exemplo, a velocidade específica máxima de crescimento, em diferentes fontes de carbono únicas (ou diferentes fontes de nitrogênio únicas). $O$ uso de meios de cultura de composição complexa não permite a realização de tais comparações e análises de forma tão quantitativa, pois com frequência contém mais de uma fonte de carbono e/ou mais de uma fonte de nitrogênio, além de não terem composição totalmente definida e de sua formulação não ser totalmente reprodutível.

Primeiramente, foram realizados cultivos em frasco agitado com diferentes meios de cultura definidos, buscando-se estabelecer uma composição de meio que proporcionasse um bom crescimento da levedura $Y$. lipolytica, ou seja, crescimento a velocidades específicas da mesma ordem de grandeza em relação àquelas observadas em meio complexo YPD, um meio que é conhecido por proporcionar um bom crescimento de diferentes espécies de leveduras.

Esses cultivos foram realizados com a linhagem $Y$. lipolytica w29 e os resultados são apresentados na Figura 10. As velocidades específicas máximas de crescimento, calculadas para estes cultivos, são apresentadas na Tabela 3. 


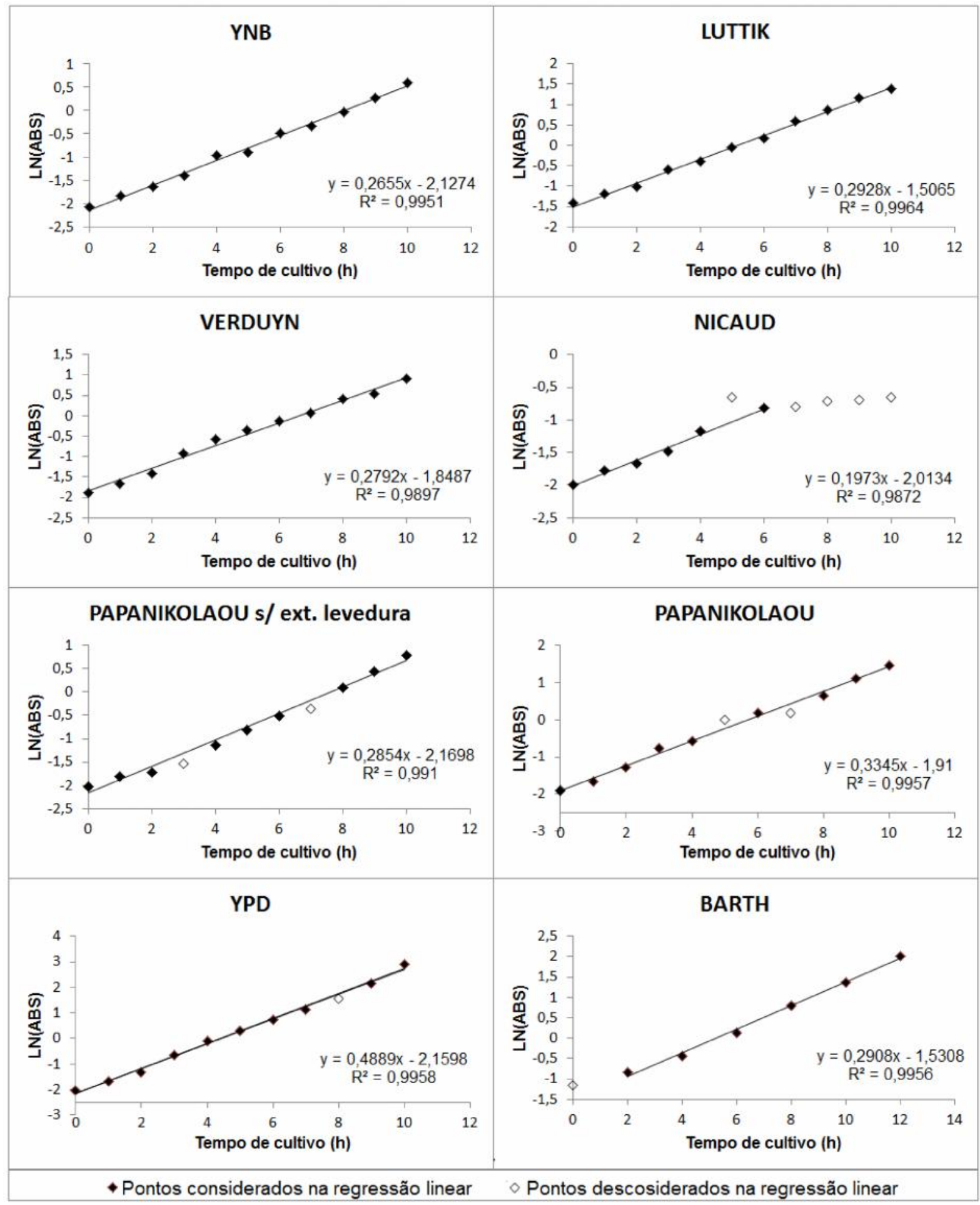

Figura 10 - Logaritmo natural da absorbância a $600 \mathrm{~nm}$ em função do tempo para cultivos com a linhagem Y. lipolytica w29 em diferentes meios de cultura, realizados a $28{ }^{\circ} \mathrm{C}$, agitação de $250 \mathrm{rpm}$ e com fonte de carbono glicose (20 g/L iniciais). As composições dos meios encontram-se descritas na Tabela 1.

Em todos os cultivos, com exceção daquele realizado em meio NICAUD, foram observadas fases exponenciais de crescimento com duração de pelo menos dez horas, sendo que os cultivos foram interrompidos antes do início da fase 
estacionária de crescimento. Durante o cultivo em meio NICAUD foi observada uma fase de crescimento exponencial com a duração de apenas seis horas, sendo também este o meio que proporcionou uma menor velocidade máxima de crescimento, dentre todos os meios estudados neste trabalho.

Como esperado, a velocidade específica máxima de crescimento no cultivo em meio YPD foi maior do que as observadas nos cultivos com meios definidos. Isso é muito provavelmente devido à presença de fontes nutricionais complexas, como o extrato de levedura e a peptona, que contém moléculas prontas para a levedura, e que, portanto, não precisam ser sintetizadas a partir da fonte de carbono e energia, como ocorre no caso dos meios definidos (Kim et al., 2000).

Durante o crescimento no meio complexo YPD, a levedura Y. lipolytica w29 apresentou velocidade específica máxima de crescimento de 0,49 $\mathrm{h}^{-1}$ (Tabela 3). Este valor é superior ao reportado na literatura para Y. lipolytica IMUFRJ 50682 $\left(0,36 \mathrm{~h}^{-1}\right)$ (Oliveira, 2009), S. cerevisiae CEN.PK113-7D $\left(0,42 \mathrm{~h}^{-1}\right)$ (Della-Bianca, 2013) e K. marxianus CBS $712\left(0,39 \mathrm{~h}^{-1}\right)$ (Lages et al., 1999), todas cultivadas em meio YPD.

Tabela 3 - Velocidades específicas máximas de crescimento da levedura $Y$. lipolytica w29, durante o crescimento em diferentes meios de cultura, em incubador rotativo

\begin{tabular}{|c|c|c|}
\hline Meio & $\mu_{\text {Máx }}\left(h^{-1}\right)$ & Repetições \\
\hline YPD & $0,49 \pm 0,02^{(\mathrm{c})}$ & 3 \\
\hline PAPANIKOLAOU (a) & $0,31 \pm 0,02^{(b)}$ & 2 \\
\hline BARTH & $0,30 \pm 0,01^{(b)}$ & 2 \\
\hline PAPANIKOLAOU sem extrato de levedura & $0,24 \pm 0,04^{(b)}$ & 2 \\
\hline LUTTIK & $0,27 \pm 0,03^{(\mathrm{c})}$ & 3 \\
\hline VERDUYN & $0,26 \pm 0,02^{(\mathrm{c})}$ & 4 \\
\hline YNB & $0,26 \pm 0,02^{(\mathrm{c})}$ & 3 \\
\hline $\operatorname{NICAUD}^{(b)}$ & 0,20 & 1 \\
\hline
\end{tabular}

* Cultivos realizados a $28{ }^{\circ} \mathrm{C}$, agitação de $250 \mathrm{rpm}$ e com fonte de carbono glicose ( $20 \mathrm{~g} / \mathrm{L}$ iniciais). As composições dos meios encontram-se descritas na Tabela 1.

(a) Esse meio contém 0,05\% de extrato de levedura sendo, portanto, um meio complexo.

(b) Desvio da Média

(c) Desvio Padrão

Através da análise estatística usando ANOVA observa-se que entre os meios definidos utilizados, o único meio que proporcionou uma velocidade específica de crescimento máxima com diferença significativa, em relação às demais situações, foi o meio NICAUD, que proporcionou uma velocidade específica de crescimento 
inferior à apresentada nos cultivos com os demais meios definidos. Entre os demais meios estudados, não foi encontrada uma diferença significativa entre as velocidades específicas de crescimento observadas, tendo sido obtido um P-valor igual a 0,0102 .

O meio BARTH possui uma composição relativamente simples (Tabela 2), já que somente contém tiamina como fator de crescimento, sendo um meio de fácil preparo, com menor custo em relação aos demais meios de cultura estudados e

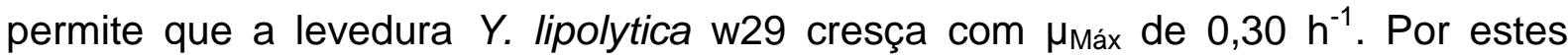
motivos, este meio foi considerado o mais adequado para a continuação dos estudos realizados neste trabalho.

Duas observações interessantes podem ser feitas quanto ao crescimento desta linhagem de $Y$. lipolytica nos meios indicados na Tabela 3. Em primeiro lugar, durante o crescimento em meio YPD notou-se que as células adquiriram uma coloração amarelo-escura, parecida à do meio de cultivo, o que se observa após centrifugação da suspensão microbiana e descarte do sobrenadante. Isto não ocorre, por exemplo, com a levedura $S$. cerevisiae quando cultivada no mesmo meio YPD, indicando a possibilidade da levedura Y. lipolytica ser capaz de adsorver ou até mesmo aderir a compostos deste meio de cultura com maior intensidade que $S$. cerevisiae (Oliveira, 2014). Uma possível explicação para essa diferença entre a levedura $Y$. lipolytica e outras espécies de leveduras seria uma maior afinidade por componentes orgânicos do meio de cultura (Amaral, 2007), uma vez que microrganismos com capacidade de consumir substratos hidrofóbicos podem apresentar uma superfície celular mais apolar, o que torna a célula mais hidrofóbica, uma característica que facilita a assimilação de tais compostos (Kim et al., 2000).

A segunda observação importante é que, enquanto $S$. cerevisiae requer diversas vitaminas para seu crescimento (conforme composição do meio VERDUYN, especialmente desenvolvido para aquela levedura, Tabela 1), Y. lipolytica somente necessita de tiamina. Pelos dados das Tabelas 1 e 3 , nota-se que a inclusão de várias outras vitaminas no meio de cultivo não resulta num aumento da velocidade específica de crescimento desta levedura.

Cabe ressaltar ainda que a velocidade específica de crescimento máxima observada para $Y$. lipolytica w29, conforme descrito neste trabalho, apesar de poder ser considerada uma velocidade satisfatória para um meio de cultura definido, está ainda distante da velocidade específica máxima atingida em meio YPD. A diferença 
relativa entre os valores de Máx de $S$. cerevisiae CEN.PK113-7D nos meios VERDUYN (definido) e YPD (complexo) (0,34 e 0,42 $\mathrm{h}^{-1}$ respectivamente; diferença porcentual de 24\%, tomando como base o menor valor) (Della-Bianca, 2013), é menor que a diferença relativa entre os valores de máx de $Y$. lipolytica nos meios BARTH (definido) e YPD (complexo) $\left(0,30\right.$ e 0,49 $\mathrm{h}^{-1}$, respectivamente; diferença porcentual de $63 \%$, tomando como base o menor valor). Isto indica que existe a possibilidade de se melhorar a composição de um meio de cultura definido para $Y$. lipolytica, de forma a se obter um valor de Máx mais próximo daquele apresentado por esta levedura em meio complexo YPD.

Em resumo, o meio BARTH possui uma composição totalmente definida e proporcionou uma velocidade específica de crescimento satisfatória para as linhagens estudadas. Sendo um meio de fácil preparo, somente com tiamina como fonte de vitamina e adequado a estudos de fisiologia quantitativa com esta levedura.

\subsection{AVALIAÇÃO DO CRESCIMENTO DA LEVEDURA Yarrowia lipolytica EM DIFERENTES FONTES DE CARBONO}

Uma das maneiras de se reduzir o custo da conversão de carboidratos a lipídios e viabilizar a produção industrial do óleo microbiano (single cell oil) é utilizar matérias-primas contendo fontes de carbono de baixo custo. Por isto, foram realizadas avaliações do crescimento das linhagens $Y$. lipolytica w29 e IMUFRJ 50682 em meio VERDUYN (definido) com diferentes fontes de carbono, e em meio BARTH, com diferentes fontes de carbono, com e sem acréscimo da solução de vitaminas descrita no item 4.3.1.2. O meio VERDUYN foi estudado com o propósito de analisar se outro meio definido (diferente do meio BARTH), com diferente composição de sais e vitaminas, eventualmente propiciaria um melhor crescimento da levedura com as fontes de carbono estudadas.

As seguintes fontes de carbono com potencial de utilização industrial foram avaliadas: sacarose (um carboidrato abundante e de baixo custo no Brasil, proveniente principalmente da cana-de-açúcar), xilose (produto da hidrólise de materiais lignocelulósicos), glicerol (subproduto da indústria do biodiesel) e também glicose, por ser uma fonte de carbono universalmente assimilada por microrganismos (um carboidrato de fácil metabolização), por ser o carboidrato mais 
abundante no planeta e também por ser frequentemente empregada em estudos acadêmicos como fonte de carbono e energia para microrganismos.

No cultivo da linhagem Y. lipolytica IMUFRJ 50682 em meio BARTH com 20 $\mathrm{g} / \mathrm{L}$ (iniciais) de glicerol como única fonte de carbono, 11,7 $\mathrm{g} / \mathrm{L}$ de biomassa seca foram gerados. Em comparação, durante o crescimento com $20 \mathrm{~g} / \mathrm{L}$ (iniciais) de glicose como única fonte de carbono, no mesmo meio BARTH, 10,4 g/L de biomassa seca foram atingidos, ou seja, houve uma conversão de glicerol em biomassa ligeiramente maior, em relação à conversão de glicose em biomassa. Como a finalidade desse estudo foi observar o crescimento ou não das linhagens em determinada fonte de carbono, não foi realizado outras análises além da concentração celular final; posteriormente, com a confirmação do crescimento, foram realizadas cinéticas de crescimento para calcular os parâmetros fisiológicos em cada fonte de carbono, itens 5.3.1 e 5.6.

Uma maior conversão de glicerol puro em biomassa, quando comparado à conversão de glicose em biomassa, foi também descrita por Papanikolaou et al. (2002) para a linhagem Y. lipolytica LGAM S(7)1. Uma maior conversão de substrato a células com a fonte de carbono glicerol, em comparação com a fonte de carbono glicose, deve-se provavelmente ao fato de o glicerol ser um substrato em que o carbono encontra-se em estado mais reduzido que o carbono presente na glicose, o que possibilita que mais energia-livre seja conservada no catabolismo de glicerol, em relação ao da glicose.

Duas moléculas de glicerol são praticamente equivalentes em carbono a uma molécula de glicose (são $72 \mathrm{~g}$ de carbono por $180 \mathrm{~g}$ ou $1 \mathrm{~mol}$, no caso da glicose e $72 \mathrm{~g}$ de carbono por $184 \mathrm{~g}$ ou 2 moles, no caso do glicerol). Na conversão de duas moléculas de glicerol a 2 moléculas de piruvato são gerados $4 \mathrm{NADH}_{2}$ e 2 ATP (Figura 11). Os $\mathrm{NADH}_{2}$ serão posteriormente reoxidados através da fosforilação oxidativa na cadeia respiratória, formando 12 ATPs (considerando-se uma estequiometria de 3 ATP gerados por $\mathrm{NADH}_{2}$ oxidado) (Nelson e Cox, 2004). Somando-se isto aos ATP gerados por fosforilação no nível do substrato, seriam 14 ATP gerados para cada 2 moles de glicerol. Em contraponto, uma molécula de glicose convertida a 2 piruvatos gera 2 ATPs (por fosforilação no nível do substrato) e $2 \mathrm{NADH}_{2}$, que serão convertidos a 6 ATPs (por fosforilação oxidativa), totalizando 8 ATPs. Nota-se assim uma diferença entre 14 ATP conservados para cada 2 moles de glicerol convertidos em piruvato e 8 ATP conservados para cada mol de glicose 
convertido em piruvato. Posteriormente, em ambos os casos, o piruvato segue o ciclo TCA, de maneira que a partir deste ponto do metabolismo os ganhos energéticos serão os mesmos no caso do glicerol e da glicose como fonte de carbono e energia.

$$
\begin{aligned}
& 2 \text { Glicerol }+2 \mathrm{ATP} \rightarrow 2 \text { 3-P-Glicerol }+2 \mathrm{ADP} \\
& 2 \text { 3-P-Glicerol }+2 \mathrm{NAD}^{+} \rightarrow 2 \text { 3-P-dihidroxiacetona + } 2 \mathrm{NADH}_{2} \\
& 2 \text { 3-P-dihidroxiacetona }+2 \mathrm{NAD}^{+}+4 \mathrm{ADP} \rightarrow 2 \text { Piruvato }+4 \mathrm{ATP}+2 \mathrm{NADH}_{2} \\
& 2 \text { Glicerol + } 4 \mathrm{NAD}^{-}+2 \mathrm{ADP} \rightarrow 4 \mathrm{NADH}_{2}+2 \mathrm{ATP}+2 \text { Piruvato }
\end{aligned}
$$

Figura 11 - Cálculo da conversão de glicerol a piruvato em Yarrowia lipolytica.

É possível também comparar a conversão global de glicerol em $\mathrm{CO}_{2}$ e $\mathrm{H}_{2} \mathrm{O}$, na presença de $\mathrm{O}_{2}$, com a conversão global de glicose em $\mathrm{CO}_{2}$ e $\mathrm{H}_{2} \mathrm{O}$, na presença de $\mathrm{O}_{2}$. Como mostrado nas reações globais abaixo, equações 6 e 7, a energia liberada através da conversão de um mol de glicose é igual a $-2872 \mathrm{KJ}$, e a energia liberada através da conversão de dois mols de glicerol é igual a - $3347 \mathrm{~kJ}$, ou seja, o metabolismo de glicerol gera $17 \%$ a mais de energia.

$$
\begin{array}{ll}
1 \text { Glicose }+6 \mathrm{O}_{2} \rightarrow 6 \mathrm{CO}_{2}+6 \mathrm{H}_{2} \mathrm{O} & \mathrm{G}_{0}=-2872 \mathrm{~kJ} \cdot \mathrm{mol}^{-1} \\
1 \text { Glicerol }+3,5 \mathrm{O}_{2} \rightarrow 3 \mathrm{CO}_{2}+4 \mathrm{H}_{2} \mathrm{O} & \mathrm{G}_{0}=-1673,5 \mathrm{~kJ}^{-1} \mathrm{~mol}^{-1}
\end{array}
$$

Através da análise da ABS(600) nos cultivos em meio liquido, foi constatado que as linhagens estudadas neste trabalho não são capazes de crescer em meio contendo somente sacarose como fonte de carbono. Esse resultado condiz com o reportado na literatura, que índica a espécie $Y$. lipolytica como sendo incapaz de assimilar sacarose (Barnett et al., 1990, Barth e Gaillardin, 1997; Förster et al., 2007). Segundo Oliveira (2014), no genoma da levedura Y. lipolytica existe um gene codificador de invertase, e portanto a incapacidade de esta levedura crescer em sacarose seria devido à incapacidade dessa espécie em expressar e secretar a enzima invertase para o periplasma, com o objetivo de hidrolisar a sacarose, assim como ocorre em $S$. cerevisiae. Alguns estudos mostram que linhagens geneticamente modificadas de Yarrowia lipolytica podem consumir sacarose como fonte de carbono, como os trabalhos de Moeller et al. (2012), Förster et al. (2007) e Lazar et al. (2013), que empregaram linhagens recombinantes de Yarrowia lipolytica 
capazes de secretar a enzima invertase, que cliva a sacarose nos monômeros glicose e frutose.

As linhagens estudadas no presente trabalho não apresentaram crescimento em xilose como única fonte de carbono. No entanto, Tsigie et al. (2011) relataram uma formação de biomassa semelhante usando fonte de carbono D-glicose (10,2 g biomassa/L) e D-Xilose (9,89 g biomassa/L), no cultivo da linhagem $Y$. lipolytica Po1g. Esse dado foi obtido em um meio contendo $5 \mathrm{~g} / \mathrm{L}$ de extrato de levedura, Szabo (1999) observou que não ocorre diminuição do crescimento de Y. lipolytica no cultivo em meio YP sem acréscimo de fonte de carbono em relação ao cultivo em meio YPD, o mesmo comportamento também foi observado por Kim et al. (2000) com as linhagens Yarrowia lipolytica CX161-1B e YLASIn. Portanto, o crescimento observado pode ser devido ao extrato de levedura e/ou à peptona presente no meio e não à fonte de carbono. No presente trabalho, observou-se a mesma formação de biomassa, com ambas as linhagens estudadas, em meio YP e em meio YP com acréscimo de fonte de carbono (glicose, glicerol, sacarose ou xilose na concentração de $20 \mathrm{~g} / \mathrm{L}$ ) (dados não apresentados). O crescimento em meio contendo extrato de levedura pode ser devido ao consumo preferencial das proteínas e aminoácidos não só como fonte de nitrogênio, mas também como fontes de carbono e de energia.

Devido às linhagens estudadas não apresentarem crescimento com xilose ou sacarose como única fonte de carbono (em ambos os meios definidos BARTH e VERDUYN, mesmo com o acréscimo da solução de vitaminas ao meio de cultura), essas fontes de carbono foram descartadas para a continuação do trabalho. Somente glicerol e glicose foram empregados como fonte de carbono a partir deste ponto do trabalho.

\subsection{CINÉTICAS DE CRESCIMENTO DE Yarrowia lipolytica EM FRASCO AGITADO}

\subsubsection{Cinética com diferentes fontes de carbono}

Para estudar os parâmetros fisiológicos das linhagens $Y$. lipolytica w29 e Y. lipolytica IMUFRJ 50682 em diferentes condições de cultivo (por exemplo, em diferentes fontes de carbono), foram realizadas cinéticas de crescimento em frasco 
agitado, em meio de cultivo definido BARTH. Glicose ou glicerol foram usados como fonte única de carbono. Os resultados são apresentados nas Figuras 12 e 13.

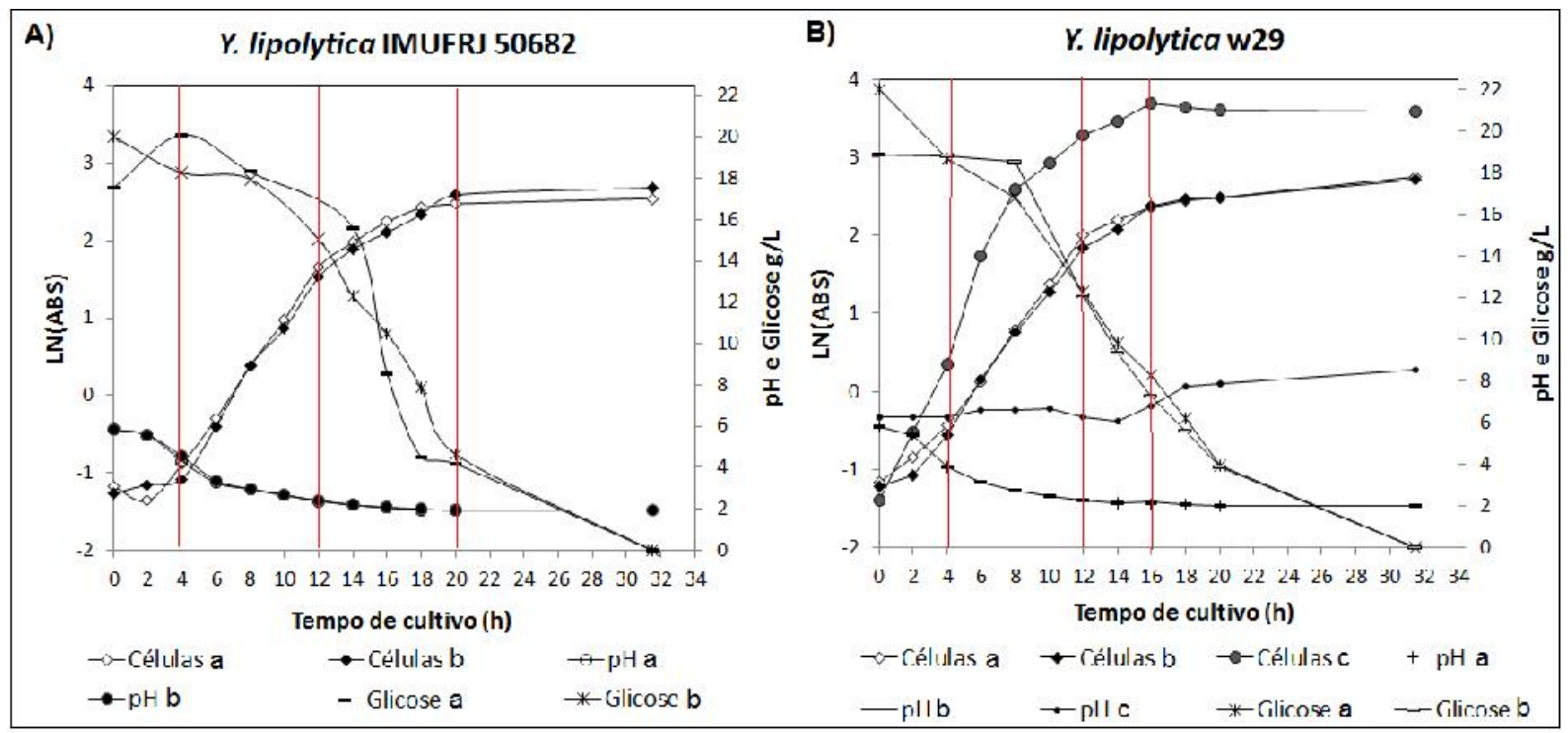

Figura 12 - Cinética em frasco com a fonte de carbono glicose. Logaritmo natural da absorbância a $600 \mathrm{~nm}, \mathrm{pH}$ e concentração de glicose em função do tempo para cultivos realizados a $28^{\circ} \mathrm{C}$, agitação de $250 \mathrm{rpm}$ com fonte de carbono glicose ( $20 \mathrm{~g} / \mathrm{L}$ iniciais) e fonte de nitrogênio sulfato de amônio (3 $\mathrm{g} / \mathrm{L}$ iniciais), com a relação $\mathrm{C} / \mathrm{N}(\mathrm{g} / \mathrm{g})$ igual a 12,6. A) Linhagem Y. lipolytica IMUFRJ 50682, a e b são duplicatas em meio definido BARTH; B) Linhagem Y. lipolytica w29. Onde a e b são duplicatas em meio definido BARTH e c cultivo em meio YPD. As linhas verticais indicam as mudanças das fases de crescimento observadas.
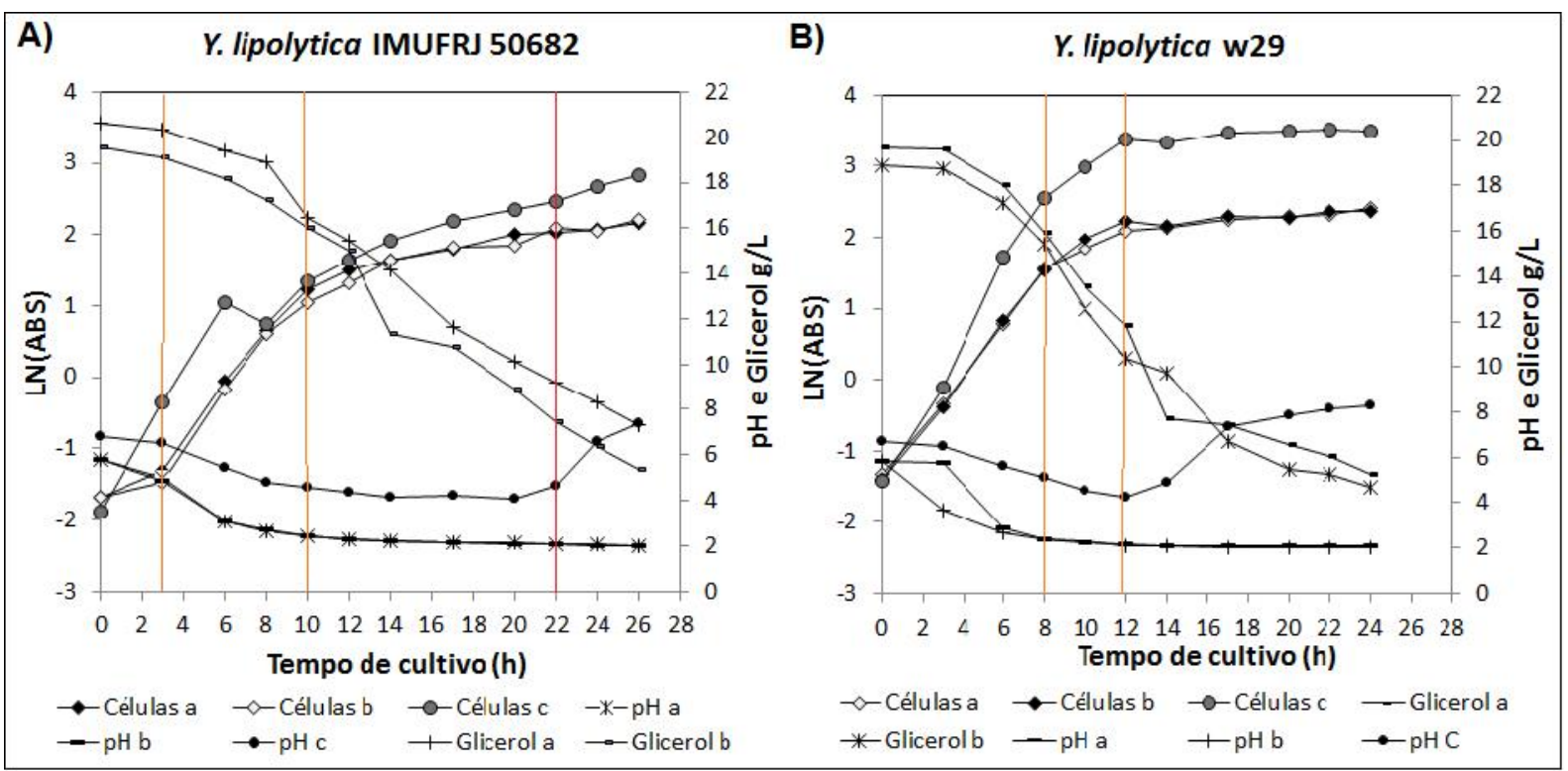

Figura 13 - Cinética em frasco com a fonte de carbono glicerol. Logaritmo natural da absorbância a $600 \mathrm{~nm}, \mathrm{pH}$ e concentração de glicerol em função do tempo para cultivos realizados a $28{ }^{\circ} \mathrm{C}$, agitação de $250 \mathrm{rpm}$ com fonte de carbono glicerol $(20,44 \mathrm{~g} / \mathrm{L}$ iniciais) e fonte de nitrogênio sulfato de amônio (3 g/L iniciais), com a relação $\mathrm{C} / \mathrm{N}(\mathrm{g} / \mathrm{g})$ igual a 12,6. a) Linhagem IMUFRJ 50682, a e b são duplicatas em meio definido BARTH e c é o cultivo em meio YPG; b) Linhagem Y. lipolytica w29, onde a e b são duplicatas em meio definido BARTH e c é o cultivo em meio YPG. Em ambos os cultivos utilizou-se $0,15 \mathrm{~mL} / \mathrm{L}$ de anti espumante, conforme detalhado em Materiais e Métodos. As linhas verticais indicam as mudanças das fases de crescimento observadas. 
Durante os cultivos com as linhagens Y. lipolytica w29 e IMUFRJ 50682, em meio BARTH com glicose, foram observadas as seguintes fases de crescimento microbiano (Figura 12): Em ambas as linhagens ocorreu uma fase de aceleração do crescimento nas primeiras 4 horas de cultivo, seguido de uma fase exponencial de crescimento de 8 horas, posteriormente houve uma fase de desaceleração do crescimento de 8 horas no cultivo com a linhagem Y. lipolytica IMUFRJ 50682 e 4 horas no cultivo com a linhagem $Y$. lipolytica w29.

No cultivo com a linhagem Y. lipolytica w29 em meio YPD (Figura 12), as células não apresentaram uma fase de aceleração do crescimento; no início do cultivo houve uma fase exponencial de crescimento com a duração de 8 horas, seguida de uma fase de desaceleração do crescimento que durou 8 horas.

Nos cultivos com a linhagem $Y$. lipolytica w29, em meio BARTH com glicerol (Figura 13), as células não apresentaram uma fase de aceleração do crescimento. No início do cultivo houve uma fase exponencial de crescimento durante 8 horas, seguido de uma fase de desaceleração do crescimento com a duração de 4 horas. A linhagem Y. lipolytica w29, em meio YPG (Figura 13), apresentou uma fase de aceleração do crescimento durante as primeiras 3 horas de cultivo, seguido de uma fase exponencial de crescimento por 5 horas, e posteriormente uma fase de desaceleração do crescimento de 4 horas.

Durante os cultivos com a linhagem Y. lipolytica IMUFRJ 50682, em meio BARTH com glicerol (Figura 13), as células apresentaram uma fase de aceleração do crescimento durante as primeiras 3 horas de cultivo, seguido de uma fase exponencial de crescimento por 7 horas, e posteriormente a fase de desaceleração do crescimento de 12 horas.

Em meio YPG a linhagem Y. lipolytica IMUFRJ 50682 não apresentou uma fase de aceleração do crescimento, iniciando o cultivo com uma fase de crescimento exponencial de 6 horas e posteriormente uma fase de desaceleração do crescimento durante 20 horas de cultivo.

As análises realizadas por HPLC mostraram que, mesmo tendo saído da fase exponencial de crescimento, as linhagens de $Y$. lipolytica não consumiram toda a fonte de carbono. Nos cultivos com ambas as linhagens $Y$. lipolytica w29 e IMUFRJ 50682, foi quantificado no início da fase de desaceleração do crescimento aproximadamente $15 \mathrm{~g} / \mathrm{L}$ de glicose no meio de cultura e no início da fase estacionária $4 \mathrm{~g} / \mathrm{L}$ de glicose. 
Nos cultivos usando glicerol como fonte de carbono, foi quantificado no início da fase de desaceleração do crescimento uma concentração de glicerol no meio de cultura de $16 \mathrm{~g} / \mathrm{L}$ nos cultivos com $Y$. lipolytica w29 e $16 \mathrm{~g} / \mathrm{L}$ nos cultivos com $Y$. lipolytica IMUFRJ 50682. No início da fase estacionária a concentração de glicerol no meio de cultura foi de aproximadamente $8 \mathrm{~g} / \mathrm{L}$ deste substrato no cultivo com a linhagem IMUFRJ 50682 e $12 \mathrm{~g} / \mathrm{L}$ no cultivo com a linhagem w29.

Isto nos levou a concluir que as células não saíram da fase exponencial de crescimento devido a uma limitação causada pela fonte de carbono. Foram levantadas três hipóteses que poderiam justificar a saída das células da fase exponencial de crescimento. A primeira hipótese seria a acentuada queda do $\mathrm{pH}$ durante os cultivos ( $\mathrm{pH}$ inicial igual a $6 \mathrm{e} \mathrm{pH}$ final igual a 2), que poderia ter causado alguma inibição ou estresse nas leveduras, provocando diminuição na velocidade específica de crescimento. Para avaliar se o pH realmente causou estresse nas linhagens e foi o fator responsável pela saída das células da fase exponencial de crescimento, foram realizadas novas cinéticas de crescimento, substituindo-se a fonte de nitrogênio $\left(\mathrm{NH}_{4}\right)_{2} \mathrm{SO}_{4}$ por ureia $\left(\mathrm{CO}\left(\mathrm{NH}_{2}\right)_{2}\right)$, com a finalidade de se evitar que o $\mathrm{pH}$ sofresse grandes variações durante o cultivo em frasco. Os dados destes cultivos são apresentados no item 5.3.2, onde foi observado o mesmo perfil de crescimento para ambas as fontes de nitrogênio, indicando que o pH não foi a causa da desaceleração da velocidade de crescimento das células.

A segunda hipótese seria uma limitação nutricional por um substrato diferente da fonte de carbono, por exemplo, a fonte de nitrogênio. É sabido que a biomassa seca de leveduras contém cerca de $48 \%$ de carbono e $7,5 \%$ de nitrogênio (MCNail e Harvey, 2008), ou seja, uma relação $\mathrm{C} / \mathrm{N}(\mathrm{g} / \mathrm{g})$ em torno de 6,4. Como o meio de cultura empregado tinha uma proporção $\mathrm{C} / \mathrm{N}(\mathrm{g} / \mathrm{g})$ de 12,6 , seria de se esperar que sobrasse carbono e que o nitrogênio passasse a ser limitante do crescimento, a menos que houvesse algum ajuste drástico da composição da biomassa da levedura.

A terceira hipótese levantada seria uma deficiência na disponibilidade de oxigênio dissolvido $\left(\mathrm{pO}_{2}\right)$ durante o cultivo, devido à baixa capacidade de aeração do meio de cultura nos cultivos em frasco agitado. Como Y. lipolytica é uma levedura estritamente aeróbia, necessita de oxigênio como aceptor final de elétrons na cadeia respiratória, o que é fundamental para que esta levedura possa conservar energialivre na forma de ATP, necessário às reações de biossíntese e à manutenção celular 
(Schmidell et al., 2001). A equação estequiométrica de oxidação completa da glicose ilustra bem a necessidade de oxigênio para este microrganismo aeróbio. Ou seja, para que ocorra a oxidação de $1 \mathrm{~mol}$ de glicose é necessário o consumo de 6 mols de $\mathrm{O}_{2}$, equação 8 (Schmidell et al., 2001).

$1 \mathrm{C}_{6} \mathrm{H}_{12} \mathrm{O}_{6}+6 \mathrm{O}_{2} \rightarrow 6 \mathrm{CO}_{2}+6 \mathrm{H}_{2} \mathrm{O}$

No entanto, a concentração de saturação de oxigênio dissolvido em água é apenas da ordem de $7 \mathrm{mg} / \mathrm{L}$ (7 ppm), à pressão de 1 atm e a $35^{\circ} \mathrm{C}$, e quando o cultivo atinge uma concentração elevada de células é necessária uma eficiente transferência de $\mathrm{O}_{2}$ para a fase líquida (Schmidell et al., 2001). No cultivo em biorreator (item 5.6), é possível observar o consumo completo de $10 \mathrm{~g} / \mathrm{L}$ de glicose em 18 horas de cultivo, sem que ocorra a diminuição da velocidade específica de crescimento. Nos cultivos em frasco (Figura 12), com a mesma concentração de nitrogênio, foram consumidos $8 \mathrm{~g} / \mathrm{L}$ de glicose antes de ocorrer a diminuição da velocidade específica de crescimento.

Nos cultivos em frasco em meio complexo (YPD e YPG) com uma relação $\mathrm{C} / \mathrm{N}$ em torno de 2 (valores de nitrogênio podem variar de acordo com o lote do produto), sendo assim rico em fonte de nitrogênio, também foi observada uma fase de diminuição da velocidade de crescimento. Contudo, seria improvável o esgotamento da fonte de nitrogênio nesse meio antes da fonte de carbono.

Portanto, a hipótese mais provável para explicar a diminuição da velocidade específica de crescimento durante os cultivos em frasco, tanto em meio definido como em meio complexo, não seria o esgotamento da fonte de nitrogênio e sim a limitação de oxigênio dissolvido no meio de cultura, devido à baixa solubilidade desse gás no meio aquoso e transferência insuficiente.

A disponibilidade de oxigênio dissolvido (pO2) é um fator muito importante em processos biotecnológicos que empregam microrganismos estritamente aeróbios, pois pode afetar não só o crescimento celular como também a produtividade do metabólito de interesse (Gomes et al., 2007; Schmidell et al., 2001). Muitos estudos comprovam uma melhora na produção do produto de interesse, associada à melhora da transferência de oxigênio para o meio de cultura. Kamzolova et al. (2003), Kamzolova et al. (2011), Rywin'ska et al. (2012), Kamzolova et al. (2013) e Morgunov et al. (2013) demonstraram que uma melhor aeração do meio de cultivo 
aumentou a produção de ácido cítrico por estirpes de Y. lipolytica. Amaral (2007) usou perfluorodecalina (PFC), um tipo de perfluorocarboneto cíclico, para aumentar a concentração de oxigênio dissolvido no meio de cultura, e assim aumentar a produção de lipase pelas linhagens Y. lipolytica IMUFRJ 50682 e w29.

A maior velocidade específica máxima de crescimento $\left(\mu_{\text {Máx }}\right)$ reportada para uma linhagem de $Y$. lipolytica, durante o crescimento com glicose como única fonte de carbono, é 0,36 $\mathrm{h}^{-1}$, para a linhagem Wratislavia K1 (Rywin'ska et al., 2010). Também foram reportadas velocidades entre 0,1 e 0,26 $\mathrm{h}^{-1}$ para cultivos usando glicerol puro como única fonte de carbono para esta mesma linhagem (Rywin'ska et al., 2010) e 0,33 $\mathrm{h}^{-1}$ no cultivo com fonte de carbono ácido oleico, para a linhagem $Y$. lipolytica ACA-DC 50109 (Papanikolaou e Aggelis, 2003). Todas essas velocidades específicas foram obtidas em cultivos com meio de cultura contendo extrato de levedura como promotor de crescimento. Ochoa-Estopier e Guillouet (2014)

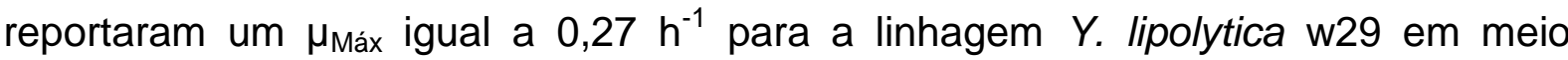
definido com glicose.

Nas cinéticas realizadas com glicose, durante este trabalho, as linhagens $Y$. lipolytica w29 e IMUFRJ 50682 apresentaram valores de $\mu_{\text {Máx }}$ de 0,30 e 0,32 h $^{-1}$ respectivamente. Esses valores de $\mu_{\text {Máx }}$ são próximos ou superiores aos valores reportados na literatura, que variam entre 0,21 a $0,36 \mathrm{~h}^{-1}$, dados mostrados na Tabela 4 (Rywin'ska et al., 2010; Ochoa-Estopier e Guillouet, 2014).

As linhagens estudadas neste trabalho apresentaram um valor de $\mu_{\text {Máx }}$ maior com glicerol como fonte de carbono, quando comparado aos cultivos com glicose. $Y$.

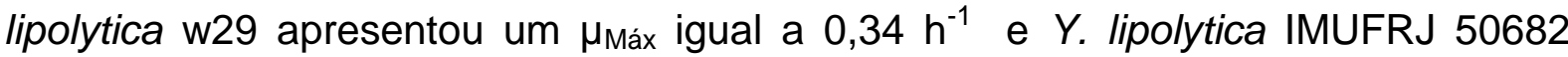

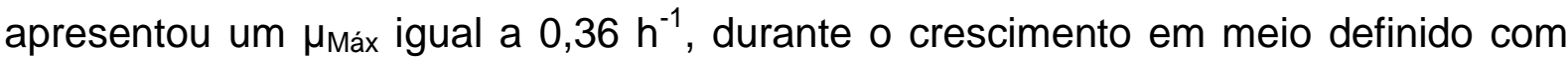
glicerol como fonte única de carbono e energia. Esses resultados indicam um grande potencial para o aproveitamento do glicerol resultante da fabricação do biodiesel, como matéria-prima de baixo custo para o cultivo de $Y$. lipolytica, objetivando a obtenção de produtos de mais alto valor agregado.

No cultivo com a linhagem Y. lipolytica IMUFRJ 50682 em meio complexo YPG, observou-se um Máx de 0,49 $\mathrm{h}^{-1}$ (Tabela 4), um Máx mais elevado que o reportado na literatura para a mesma linhagem em meio YPD $\left(0,36 \mathrm{~h}^{-1}\right)$ (Oliveira, 2009). 
Tabela 4 - Velocidades específicas máximas de crescimento e fatores de conversão de substrato a células de diferentes linhagens de $Y$. lipolytica.

\begin{tabular}{|c|c|c|c|c|}
\hline Linhagem & Meio de cultura & $\mu_{\text {Máx. }}\left(h^{-1}\right)^{(b)}$ & $\mathrm{Y}_{\mathrm{X} / \mathrm{S}}^{(\mathrm{c})}$ & Fonte \\
\hline \multirow{6}{*}{$\begin{array}{l}\text { Y. lipolytica } \\
\text { IMUFRJ 50682 }\end{array}$} & Definido glicose & $0,32 \pm 0,00$ & $0,49 \pm 0,16$ & Este trabalho \\
\hline & Definido glicose & 0,35 & 0,32 & Oliveira, 2014 \\
\hline & YPG & 0,49 & & Este trabalho \\
\hline & YPD & 0,36 & & Oliveira, 2009 \\
\hline & Definido glicerol & $0,36 \pm 0,00$ & $0,58 \pm 0,02$ & Este trabalho \\
\hline & Definido glicerol & 0,46 & 0,48 & Oliveira, 2014 \\
\hline \multirow{7}{*}{ Y. lipolytica w29 } & Definido glicose & $0,30 \pm 0,00$ & $0,73 \pm 0,04$ & Este trabalho \\
\hline & Definido glicose & 0,27 & 0,35 & Oliveira, 2014 \\
\hline & Definido glicose & 0,27 & 0,49 & $\begin{array}{l}\text { Ochoa-Estopier e Guillouet, } \\
2014\end{array}$ \\
\hline & YPD & 0,51 & & Este trabalho \\
\hline & YPG & 0,51 & & Este trabalho \\
\hline & Definido glicerol & $0,34 \pm 0,01$ & $0,71 \pm 0,04$ & Este trabalho \\
\hline & Definido glicerol & 0,36 & 0,51 & Oliveira, 2014 \\
\hline \multirow{3}{*}{$\begin{array}{l}\text { Y. lipolytica } \\
\text { Wratislavia AWG7 }\end{array}$} & Complexo glicose & 0,36 & & Rywin'ska et al., 2010 \\
\hline & Complexo glicerol & 0,26 & & Rywin'ska et al., 2010 \\
\hline & Complexo glicerol & & 0,47 & Rywin'ska et al., 2009 \\
\hline Y. lipolytica S17 & Complexo glicerol & & 0,56 & Juszczyk et al., 2013 \\
\hline Y. lipolytica IBT & Definido glicose & & 0,24 & Workman et al., 2013 \\
\hline 446 & Definido glicerol & & 0,32 & Workman et al., 2013 \\
\hline \multirow{3}{*}{$\begin{array}{l}\text { Y. lipolytica LGAM } \\
\mathrm{S}(7) 1\end{array}$} & Complexo glicose & 0,21 & 0,45 & Papanikolaou et al., 2006 \\
\hline & Complexo glicose & & 0,22 & Papanikolaou et al., 2002 \\
\hline & Complexo glicerol & & 0,23 & Papanikolaou et al., 2002 \\
\hline
\end{tabular}

(a) Os dados com Y. lipolytica IMUFRJ 50682 em meio YPD foram descartados devido à excessiva formação de espuma no meio e consequente dificuldade na leitura da ABS(600);

(b) Desvio da média (experimentos realizados em duplicata);

${ }^{(c)}$ Devido a problemas na análise da concentração celular, por causa da formação de espuma no cultivo, não foi possível calcular os dados em meio YPD.

Não é possível concluir que a maior velocidade de crescimento observada no presente trabalho, em comparação com o dado da literatura, seja devido ao uso do glicerol como fonte de carbono, em vez da glicose, pois não conseguimos realizar um cultivo em meio YPD com êxito. Além disto, como apresentado na Tabela 4, a fonte de carbono em meio complexo não alterou a velocidade específica máxima de 
crescimento da linhagem w29, que apresentou um Máx de $0,51 \mathrm{~h}^{-1}$ no cultivo com ambas as fontes de carbono, glicose (YPD) ou glicerol (YPG).

Através das duplicatas dos cultivos (Figuras 12 e 13) e dos valores de $\mu_{\text {Máx }}$ observados nos cultivos da $Y$. lipolytica w29, 0,49 e 0,51 $\mathrm{h}^{-1}$ (Tabelas 3 e 4, respectivamente), é possível observar que os experimentos possuem uma boa reprodutibilidade.

Constatou-se que a linhagem Y. lipolytica w29, em ambas as fontes de carbono estudadas (glicose ou glicerol), possui um maior fator de conversão substrato a célula ( $\left.\mathrm{Y}_{\mathrm{X} / \mathrm{S}}\right)$ do que a linhagem Y. lipolytica IMUFRJ 50682 (Tabela 4).

Ambas as linhagens estudadas não apresentaram diferença significativa no $Y_{X / S}$ nos cultivos com glicose ou glicerol, ou seja, a fonte de carbono não alterou o fator de conversão substrato a célula das linhagens estudadas (cálculo indicado no Apêndice $A$ deste trabalho). Esse resultado contradiz com o esperado pois, como demonstrado no item 5.2, o glicerol é capaz de fornecer maior quantidade de energia para a célula em relação a glicose. Papanikolaou et al. (2002) também observaram no cultivo da linhagem $Y$. lipolytica LGAM S(7)1 fatores de conversão substrato a célula semelhantes em glicose $\left.(0,22 \text { (g DW).(g glucose })^{-1}\right)$ e glicerol $(0,23$ (g DW).(g

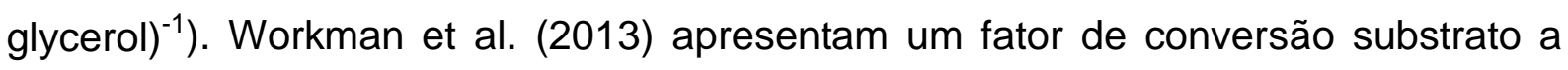
célula maior em glicerol, em relação ao $\mathrm{Y}_{\mathrm{X} / \mathrm{S}}$ do cultivo em glicose, com a linhagem $Y$. lipolytica IBT 446, no entanto inferiores aos obtidos para ambas as linhagens estudadas no presente trabalho (Tabela 4).

Oliveira (2014) comparou duas linhagens de Y. lipolytica (IMUFRJ 50682 e w29) e observou um maior $Y_{X / S}$ em glicerol, 0,48 e 0,51 (g DW).(g glycerol $)^{-1}$, respectivamente, quando comparado ao cultivo em glicose, 0,32 e 0,35 (g DW).(g glucose $)^{-1}$, respectivamente. No entanto, esses valores foram inferiores aos obtidos no presente trabalho.

Ambas as linhagens estudadas apresentaram um maior fator de conversão substrato a célula, com fonte de carbono glicerol, do que o observado por Rywin'ska et al. (2009) que relatam um $Y_{X / S}$ de 0,47 (g DW).(g glycerol $)^{-1}$ para a linhagem $Y$. lipolytica LGAM S(7)1.

O maior fator de conversão substrato a células obtido com a linhagem $Y$. lipolytica w29 (0,71 (g DW).(g glycerol $\left.)^{-1}\right)$, foi superior ao obtido por Juszczyk et al (2013) com a linhagem Y. lipolytica $\left.\mathrm{S} 17(0,56 \mathrm{~g} \text { (g DW).(g glycerol) })^{-1}\right)$, em meio 
complexo. Esse elevado fator de conversão substrato a células obtido com a linhagem Y. lipolytica w29, com ambas as fontes de carbono glicose e glicerol, podem ter sido superestimado, uma vez que Ochoa-Estopier e Guillouet (2014) obtiveram um $\mathrm{Y}_{\mathrm{X} / \mathrm{S}}$ de 0,49 (g DW).(g glucose $)^{-1}$ com a mesma linhagem em meio definido.

Em resumo, as linhagens de Y. lipolytica IMUFRJ 50682 e w29 crescem com velocidade específica de crescimento máxima ( Máx) em torno de $0,49 \mathrm{~h}^{-1}$ em meio complexo contendo extrato de levedura, peptona e glicose ou glicerol como fonte de carbono. Crescem com Máx em torno de $0,31 \mathrm{~h}^{-1}$ em meio definido com glicose como única fonte de carbono e em torno de $0,35 \mathrm{~h}^{-1}$ no mesmo meio, mas com glicerol como única fonte de carbono, sem excreção de metabólitos para o meio de cultivo.

\subsubsection{Cinética com diferentes fontes de nitrogênio}

Foi observado durante as cinéticas de crescimento com sulfato de amônio que o $\mathrm{pH}$ durante os cultivos diminuía drasticamente, chegando a valores próximos de 2, o que certamente causa estresse na levedura, podendo comprometer seriamente a viabilidade da população microbiana. Essa queda de $\mathrm{pH}$ ocorre devido ao sistema de transporte do íon amônio para dentro da célula, que envolve o antiporte de prótons para fora da célula (Moo-Young, 1985). Portanto, para minimizar a variação do $\mathrm{pH}$ durante os cultivos, o sulfato de amônio foi substituído por ureia como fonte de nitrogênio, mantendo-se a mesma concentração molar de nitrogênio. O enxofre do sulfato de amônio não foi substituído, uma vez que o sulfato de magnésio adicionado ao meio proporcionou enxofre para a levedura e, no meio original descrito por Barth e Gaillardin (1996), usa-se $\left(\mathrm{NH}_{4}\right) \mathrm{H}_{2} \mathrm{PO}_{4}$, ou seja, a substituição do sulfato de amônio por ureia não restringirá o enxofre do meio de cultura. Nos cultivos com ureia, a queda do pH não é tão brusca, devido à atividade da urease, que transforma a ureia em amônia e $\mathrm{CO}_{2}$, no meio de cultura, isso eleva o pH do meio e, posteriormente, quando a amônia é consumida pela levedura o pH é reduzido (Moo-Young, 1985).

Os resultados apresentados na Figura 14 indicam um crescimento da levedura $Y$. lipolytica semelhante nas duas fontes de nitrogênio, pois foram 
observados valores de $\mu_{\text {Máx }}$ iguais a $0,28 \mathrm{~h}^{-1}$ e $0,32 \mathrm{~h}^{-1}$ no cultivo com ureia e com sulfato de amônio, respectivamente. Como previsto, o pH final do cultivo no meio com ureia (em torno de 4) foi mais próximo do $\mathrm{pH}$ inicial do cultivo $(6,8)$, se comparado ao cultivo com sulfato de amônio, em que o pH inicial foi igual a $6 \mathrm{e} \mathrm{opH}$ final chegou a 2,0.

Constatou-se que em ambas as fontes de nitrogênio as linhagens apresentaram o mesmo padrão de crescimento, ou seja, a redução da velocidade específica de crescimento passou a ocorrer muito antes do esgotamento da fonte de carbono. Desta forma, a hipótese de que o pH seria o responsável pela saída das células da fase exponencial de crescimento pôde ser definitivamente descartada. Uma limitação do crescimento pela falta de outro nutriente do meio, como nitrogênio ou oxigênio, é a causa mais provável para que as células deixem de crescer com velocidade específica máxima, nestes experimentos. Como discutido no item 5.3.1, em função dos resultados dos cultivos em biorreator (item 5.6) e dos cultivos em frasco agitado realizados em meio complexo (item 5.3.1), a hipótese mais provável para explicar a diminuição da velocidade específica de crescimento durante os cultivos em frasco, tanto em meio definido como em meio complexo, não seria o esgotamento da fonte de nitrogênio e sim a limitação de oxigênio dissolvido no meio de cultura, devido à baixa solubilidade desse gás em meio aquoso.

Apesar do uso da ureia evitar uma queda mais acentuada do $\mathrm{pH}$ do meio durante o cultivo, decidiu-se por manter o sulfato de amônio como fonte de nitrogênio nos estudos posteriores em biorreator, uma vez que neste sistema de cultivo é possível controlar o pH. O uso do sulfato de amônio facilita a preparação dos meios de cultivo, pois este composto pode ser esterilizado em autoclave juntamente com os demais nutrientes, ao contrário da ureia, que se degrada com o calor, requerendo, portanto, um procedimento separado de esterilização por filtração. 


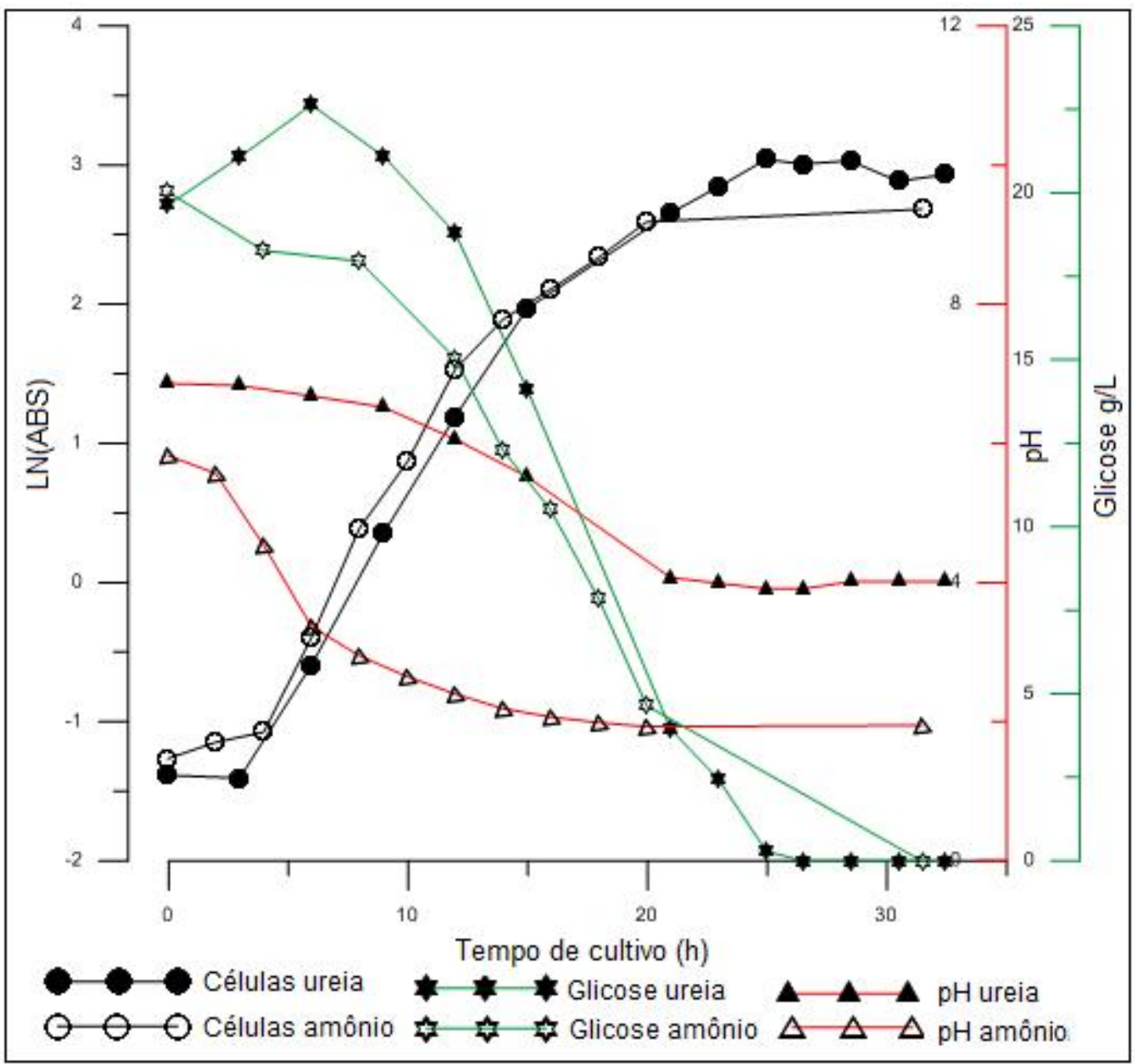

Figura 14 - Cultivos realizados com a linhagem Y. lipolytica IMUFRJ $50682 \mathrm{com}$ as fontes de nitrogênio uréia $(1,1 \mathrm{~g} / \mathrm{L}$ iniciais e $\mathrm{pH} 6,8)$ e sulfato de amônio $(3 \mathrm{~g} / \mathrm{L}$ iniciais e $\mathrm{pH}$ 6), em meio BARTH, a $28{ }^{\circ} \mathrm{C}$, agitação de $250 \mathrm{rpm}$ e glicose $(20 \mathrm{~g} / \mathrm{L}$ iniciais) como fonte de carbono. Logaritmo natural da absorbância a $600 \mathrm{~nm}$, concentração de glicose e pH. Em ambos os cultivos manteve-se a relação $\mathrm{C} / \mathrm{N}(\mathrm{g} / \mathrm{g})$ inicial igual a 12,6 .

\subsubsection{Cinética de crescimento com restrição da fonte de nitrogênio}

Para estudar a formação de partículas lipídicas na levedura $Y$. lipolytica, costuma-se proporcionar uma limitação de algum nutriente no meio de cultivo, diferente da fonte de carbono. O nutriente limitante mais eficiente e comumente utilizado para o estudo da formação de partículas lipídicas na levedura Y. lipolytica é o nitrogênio (Wolinski e Kohlwein, 2008). Portanto, foram realizadas cinéticas de crescimento em frasco com as linhagens Y. lipolytica IMUFRJ 50682 e w29, com a concentração de sulfato de amônio 10 vezes menor que a referência (Barth e Gaillardin, 1996), ou seja, 0,3 g/L, em vez de $3 \mathrm{~g} / \mathrm{L}$. Nesta nova condição, a relação 
$\mathrm{C} / \mathrm{N}$ foi de 126 , em vez de 12,6 . Os resultados destes cultivos estão expostos na Figura 15.

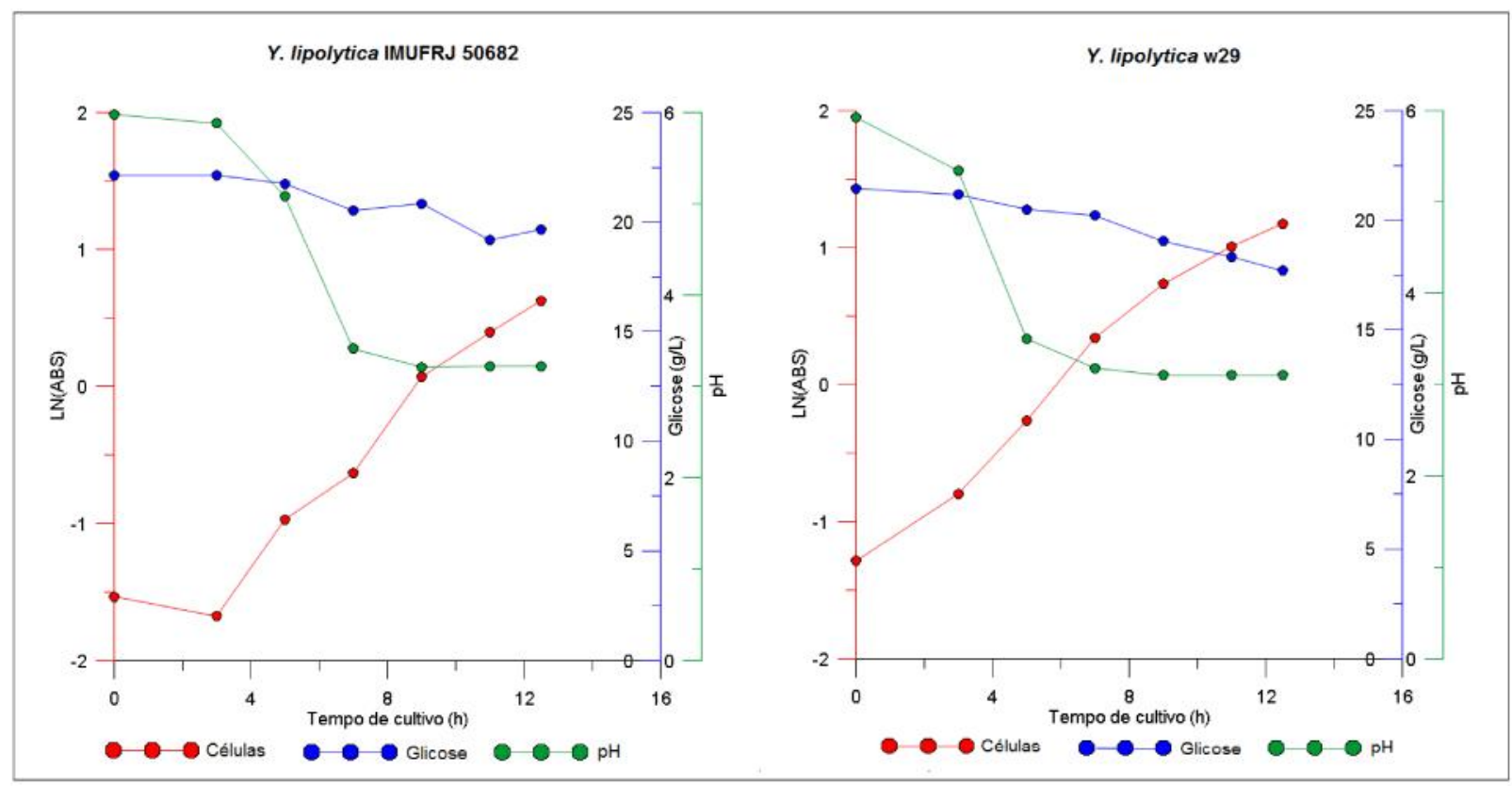

Figura 15 - Cinética de crescimento com restrição da fonte de nitrogênio. Logaritmo natural da absorbância a $600 \mathrm{~nm}$, concentração de glicose e $\mathrm{pH}$ em função do tempo para cultivos realizados com as linhagens $Y$. lipolytica IMUFRJ 50682 e w29 a $28{ }^{\circ} \mathrm{C}$, agitação de $250 \mathrm{rpm}$ com fonte de carbono glicose (20 g/L iniciais) e fonte de nitrogênio sulfato de amônio (0,3 g/L iniciais). Relação $\mathrm{C} / \mathrm{N}$ igual a 126.

Observou-se que as células do cultivo com restrição da fonte de nitrogênio saíram da fase de crescimento exponencial após cerca de 9 horas de cultivo, juntamente com a estabilização do pH do cultivo em torno de 3,1 (Tabela 5 e Figura 15). Nos cultivos referência (relação $C / N 12,6$ ) foi observada a saída das células da fase de crescimento exponencial após cerca de 12 horas de cultivo com $20 \mathrm{~g} / \mathrm{L}$ iniciais de glicose e um pH final próximo de 2 (Figura 12).

Tabela 5 - Comparação entre os cultivos com restrição da fonte de nitrogênio (relação $\mathrm{C} / \mathrm{N}$ inicial 126) e sem restrição da fonte de nitrogênio (relação $\mathrm{C} / \mathrm{N}$ inicial 12,6).

\begin{tabular}{cccccc}
\hline Linhagem & $\begin{array}{c}\text { Concentração de } \\
\text { sulfato de amônio }\end{array}$ & Relação C/N & $\mu_{\text {Máx. }}\left(\mathrm{h}^{-1}\right)^{(\mathrm{a})}$ & $\begin{array}{c}\mathrm{X}_{\text {Final }} \\
(\mathrm{g} \mathrm{DW} / \mathrm{L})\end{array}$ & $\begin{array}{c}\text { Fim da fase } \\
\text { exponencial de } \\
\text { crescimento }(\mathrm{h})\end{array}$ \\
\hline Y. lipolytica & $3 \mathrm{~g} / \mathrm{L}$ & 12,6 & $0,32 \pm 0,00$ & 6,8 & 12 \\
IMUFRJ 50682 & $0,3 \mathrm{~g} / \mathrm{L}$ & 126 & 0,28 & 1,6 & 9 \\
\hline Y. lipolytica w29 & $3 \mathrm{~g} / \mathrm{L}$ & 12,6 & $0,30 \pm 0,00$ & 7 & 12 \\
& $0,3 \mathrm{~g} / \mathrm{L}$ & 126 & 0,28 & 1,74 & 9 \\
\hline
\end{tabular}

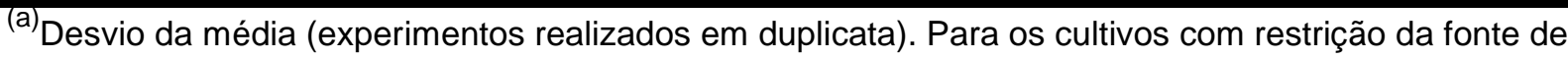
$\mathrm{N}$, não foram realizadas replicatas. 
A concentração celular no final do cultivo com restrição da fonte de nitrogênio (Tabela 5) foi significantemente menor (78\% menor no caso da linhagem IMUFRJ 50682 e 75\% menor no caso da linhagem w29) do que a concentração celular obtida em cinéticas com relação $\mathrm{C} / \mathrm{N}$ igual a 12,6. A quantidade de glicose consumida por ambas as linhagens foi de somente $3 \mathrm{~g} / \mathrm{L}$, não ocorrendo o esgotamento deste substrato em $13 \mathrm{~h}$ de cultivo. Nos cultivos com excesso de nitrogênio (C/N 12,6), o consumo de glicose foi de $8 \mathrm{~g} / \mathrm{L}$, antes de ocorrer a desaceleração do crescimento ao final da fase exponencial e somente $4 \mathrm{~g} / \mathrm{L}$ de glicose restavam no meio, no instante em que as células atingiram a fase estacionária (Figura 12). Desta forma, foi concluído que no cultivo com relação $\mathrm{C} / \mathrm{N} 126$ a fonte de nitrogênio foi o nutriente limitante, a partir do instante em que as células saíram da fase exponencial de crescimento, sendo este o motivo para a entrada das células na fase de redução de velocidade (Monod, 1949).

No entanto, mesmo após as células terem saído da fase exponencial de crescimento, ainda foi observado um aumento na $A B S(600)$ da cultura, o que pode ser explicado pela modificação da morfologia e tamanho das células, como observado na Figura 16. Essas modificações podem ser atribuídas ao dimorfismo característico da levedura $Y$. lipolytica, pois sua morfologia varia de acordo com as condições ambientais (aeração, fonte de carbono e de nitrogênio, pH, etc.) e pelo genótipo da linhagem (Barth e Gaillardin, 1997).

A diminuição da concentração de glicose após o final da fase exponencial de crescimento pode ser explicada pelo consumo para a manutenção celular e pelo acúmulo de reservas energéticas na forma de lipídios neutros, o que pode ser observado na Figura 16 pelo aumento do tamanho e do número de partículas lipídicas. É possível analisar qualitativamente, através da Figura 16b, que a linhagem w29 acumula uma boa quantidade de lipídios quando cultivada com glicose em excesso e com restrição de fonte de nitrogênio. Pois na Figura 16a, as células vieram de um inóculo cultivado sem restrição da fonte de nitrogênio. 


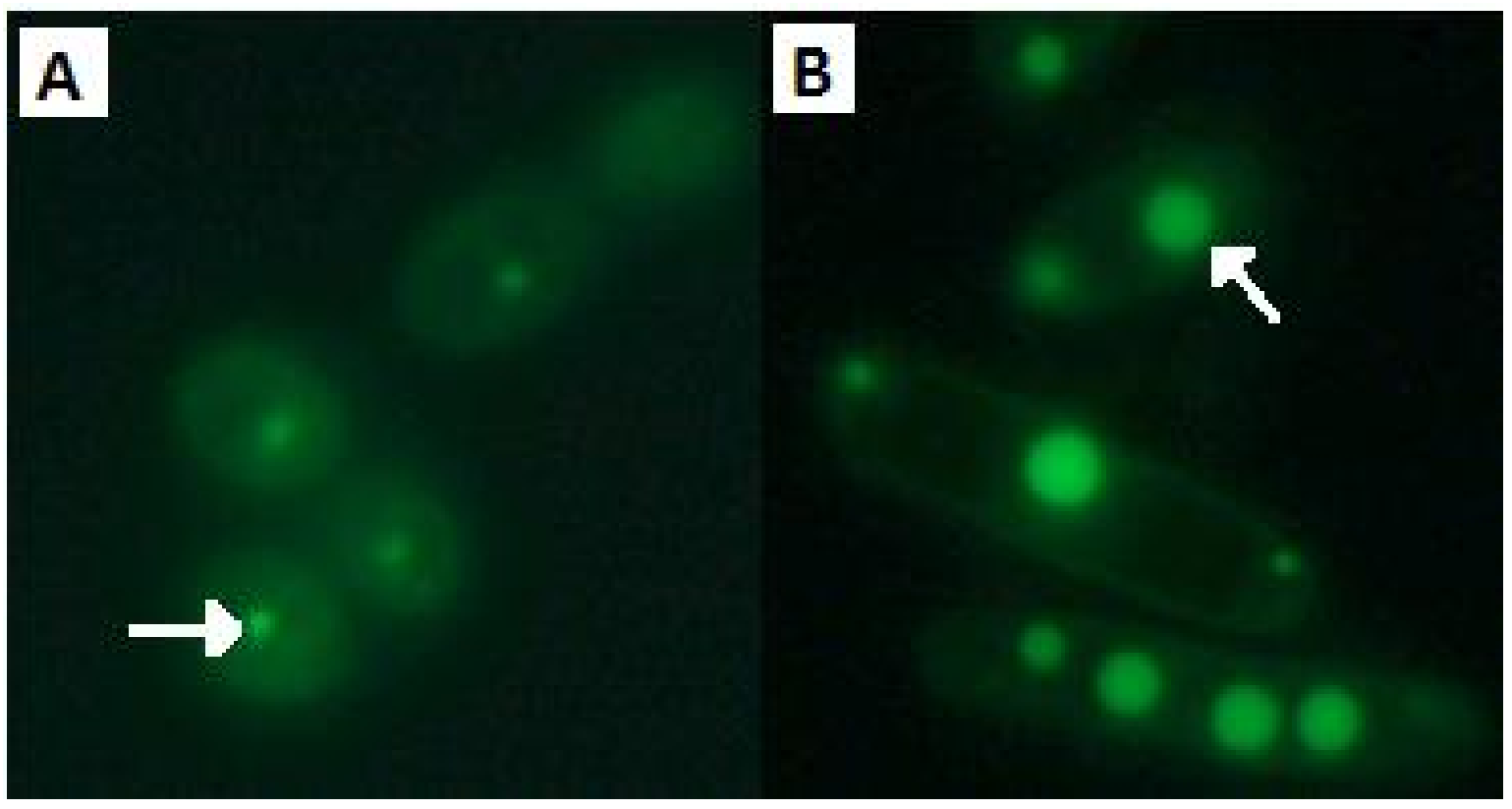

Figura 16 - Imagem de microscopia com aumento de 100 vezes e coloração das PLs com BODIPY 493/503. A) Y. lipolytica w29 na forma leveduriforme, amostra retirada no instante da inoculação; B) Y. lipolytica w29 na forma de hifas e aumento das PLs devido à limitação de nitrogênio, amostra retirada no final do cultivo. (Imagens igualmente ampliadas para melhor visualização)

\subsection{ANÁLISE DE PARTÍCULAS LIPÍDICAS}

Para realizar o estudo da influência da velocidade específica de crescimento no metabolismo lipídico da levedura Yarrowia lipolytica, conforme havíamos previsto como objetivo principal deste trabalho, a formação das partículas lipídicas foi quantificada através da análise de imagens adquiridas por microscopia de fluorescência. Por conta disso, foi realizada uma visita ao Laboratório de Biologia Molecular de Leveduras do Instituto de Bioquímica Médica na Universidade Federal do Rio de Janeiro, com a supervisão da colaboradora do projeto Prof. ${ }^{a}$ Monica Montero Lomeli, com o intuito de estabelecer um protocolo para coloração das partículas lipídicas.

\subsubsection{Cinéticas de crescimento}

Para analisar partículas lipídicas foram realizados cultivos de $5 \mathrm{~h}$, dos quais foram retiradas amostras que posteriormente foram tratadas e armazenadas, 
conforme descrito em Materiais e Métodos. As velocidades específicas máximas obtidas nos cultivos estão indicadas na Tabela 6.

Tabela 6 - Velocidades específicas máximas das linhagens de levedura empregadas nos estudos de obtenção de imagens de partículas lipídicas

\begin{tabular}{ccc}
\hline Linhagem & Meio de cultura & $\mu_{\text {Máx. }}\left(\mathrm{h}^{-1}\right)$ \\
\hline Y. lipolytica IMUFRJ & YPD & 0,46 \\
50682 & YNB & 0,44 \\
\hline S.cerevisiae BY4741 & YPD & 0,36 \\
\hline
\end{tabular}

No cultivo em meio complexo YPD, a levedura Y. lipolytica IMUFRJ 50682 apresentou uma velocidade específica máxima de crescimento de 0,46 $\mathrm{h}^{-1}$ (Tabela 6). Este valor é superior ao reportado na literatura para a mesma linhagem $\left(0,36 \mathrm{~h}^{-1}\right)$ (Oliveira, 2009), e próximo ao obtido neste trabalho no cultivo em meio YPG $\left(0,49 \mathrm{~h}^{-}\right.$ $\left.{ }^{1}\right)$ e ao valor obtido para a linhagem w29 em meio YPD $\left(0,51 \mathrm{~h}^{-1}\right)$ (Tabela 4). No cultivo com a linhagem Y. lipolytica IMUFRJ 50682, em meio YPD, foi possível realizar medidas satisfatórias da ABS(600) apesar da formação de espuma no meio, o que não foi possível no cultivo do item 5.3.1 deste trabalho.

No cultivo em meio YNB a levedura Y. lipolytica IMUFRJ 50682 apresentou uma velocidade específica máxima de crescimento de $0,44 \mathrm{~h}^{-1}$, valor acima do esperado devido aos resultados obtidos com a linhagem w29 em meio YNB $\left(0,27 \mathrm{~h}^{-}\right.$ $\left.{ }^{1}\right)$ (Tabela 3). No entanto, esse crescimento pode ser devido a uma ineficiente lavagem das células do inóculo e da característica da levedura em carregar compostos do meio complexo YPD para o meio YNB, conforme discutido no item 5.1 desse trabalho e conforme também observado por Oliveira (2014).

No cultivo em meio complexo YPD, a levedura $S$. cerevisiae BY4741 apresentou uma velocidade específica máxima de crescimento de 0,36 $\mathrm{h}^{-1}$, valor inferior ao observado por Corbacho et al. (2011) com a mesma linhagem $\left(0,51 \mathrm{~h}^{-1}\right)$ e também inferior ao apresentado pela linhagem $S$. cerevisiae CEN.PK113-7D $\left(0,42 \mathrm{~h}^{-}\right.$ ${ }^{1}$ ) (Della-Bianca, 2013), ambos cultivos no mesmo meio YPD. 


\subsubsection{Análise de PLs por microscopia}

\section{Saccharomyces cerevisiae BY4741}

Foi escolhido o ponto de $4 \mathrm{~h}$ para análise microscópica (Figura 17), pois foi o ponto que inicialmente indicou uma maior concentração de partículas lipídicas antes de serem feitos os cálculos reais da análise de fluorescência.

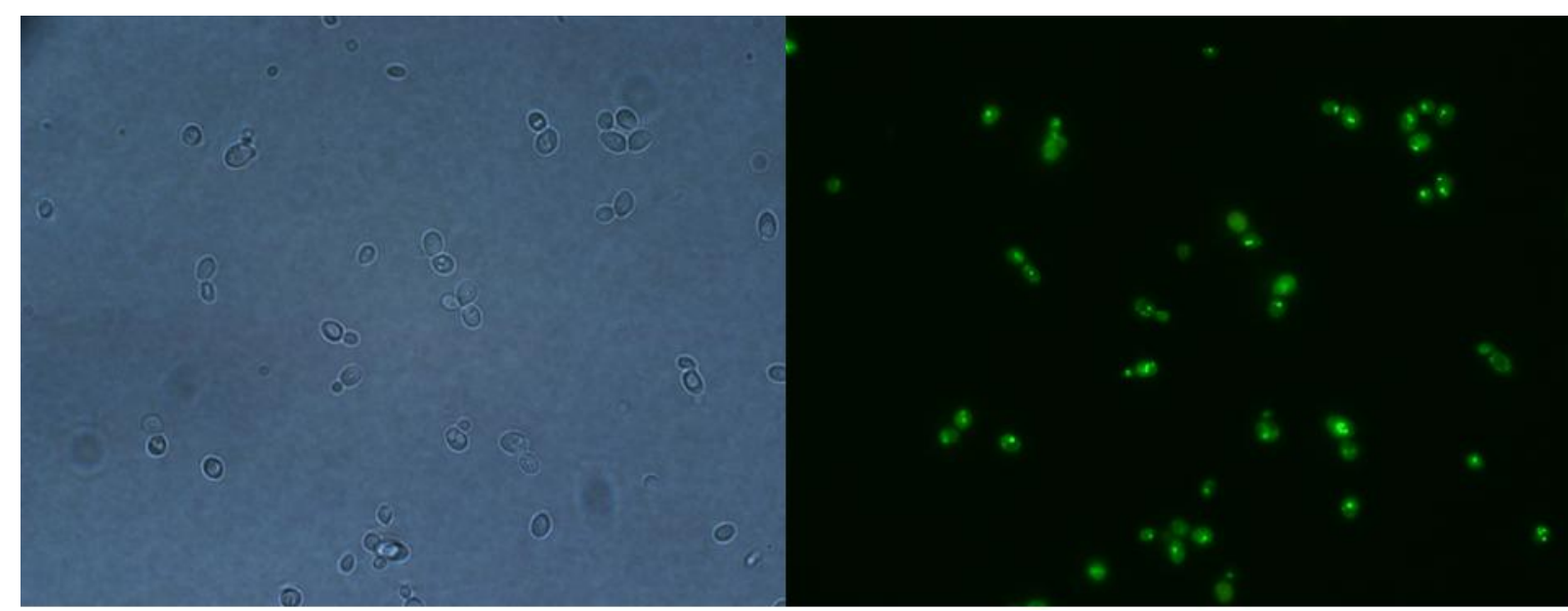

Figura 17 - Células de S. cerevisiae BY4741 em $4 \mathrm{~h}$ de cultivo em meio YPD, fixadas com formaldeído. A imagem esquerda sem fluorescência e a direita com fluorescência.

\section{Yarrowia lipolytica IMUFRJ 50682}

Observou-se que a fixação da levedura Yarrowia lipolytica com formaldeído afeta a coloração das células com a sonda BODIPY 493/503, pois como pode ser observado na Figura 18, não é possível distinguir as PLs devido à alta fluorescência em toda a célula. Na Figura 19 pode-se observar a diferença entre as células fixadas com formaldeído e células sem fixação, amostradas no mesmo instante de cultivo. Observa-se que as células sem fixação possuem uma melhor qualidade na definição das PLs pelo BODIPY 493/503. Portanto, optou-se pela não fixação das células nas posteriores análises.

Embora o mecanismo de ação do formaldeído na célula não esteja totalmente esclarecido, Mason e O'leary (1991) observaram que, em solução salina de formol, o formaldeído atua junto aos microtúbulos ligando-se $a$ e $b$ tubulina, despolimerizando a estrutura tubular e desnaturando as proteínas presentes na membrana plasmática. Essa desnaturação proteica, segundo análises de Zhu et al. 
(2002), promovem alterações na permeabilidade da membrana que dificultam ou impedem o transporte de água para dentro da célula. Provavelmente seja essa alteração na permeabilidade da membrana plasmática que impede a entrada da sonda fluorescente, dissolvida em água, para dentro da célula impedindo assim a coloração das PLs.

Como discutido no item 5.1, a levedura Y. lipolytica em comparação outras espécies de leveduras possui uma superfície celular com características diferenciadas. Sendo assim, uma hipótese que justifique uma fixação ineficiente em Yarrowia lipolytica, em comparação com $S$. cerevisiae, seria a célula sofrer maior ação do formaldeído devido às diferenças na membrana celular.

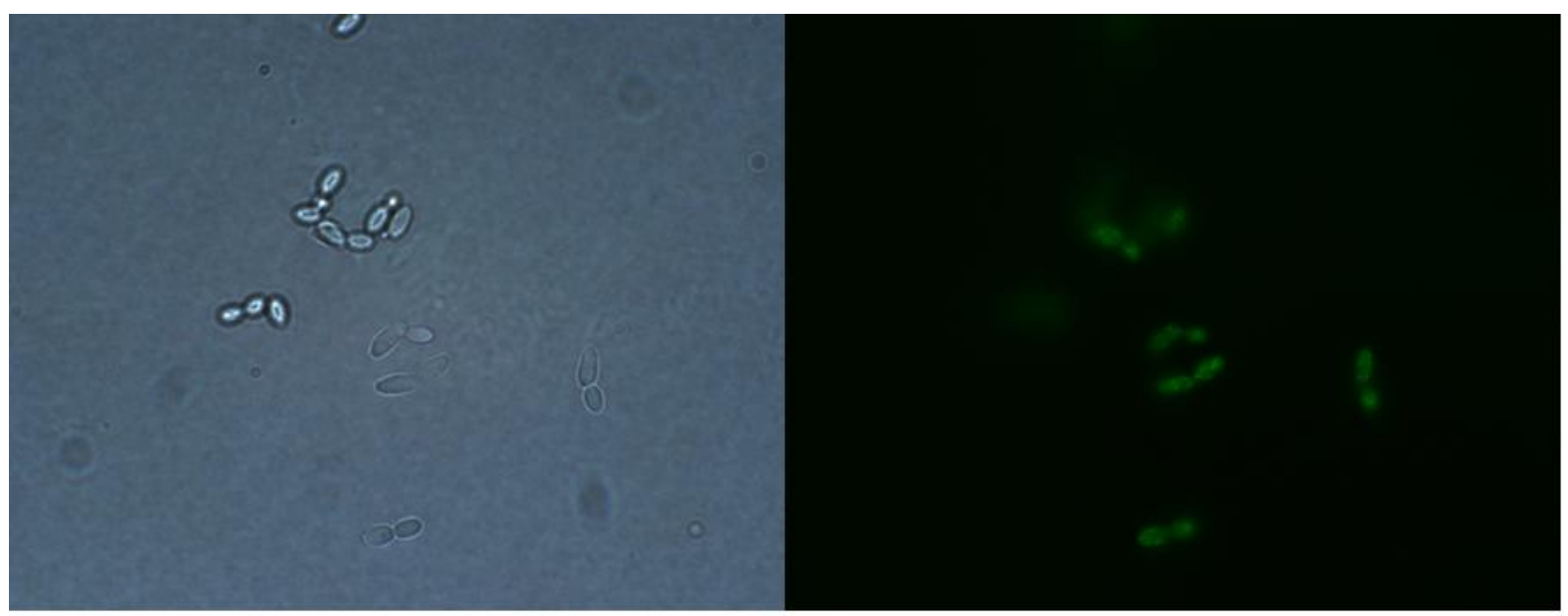

Figura 18 - Yarrowia lipolytica IMUFRJ 50682 cultivada em meio YPD por $4 \mathrm{~h}$ e fixada em formaldeído, imagem esquerda sem fluorescência e imagem direita com fluorescência.

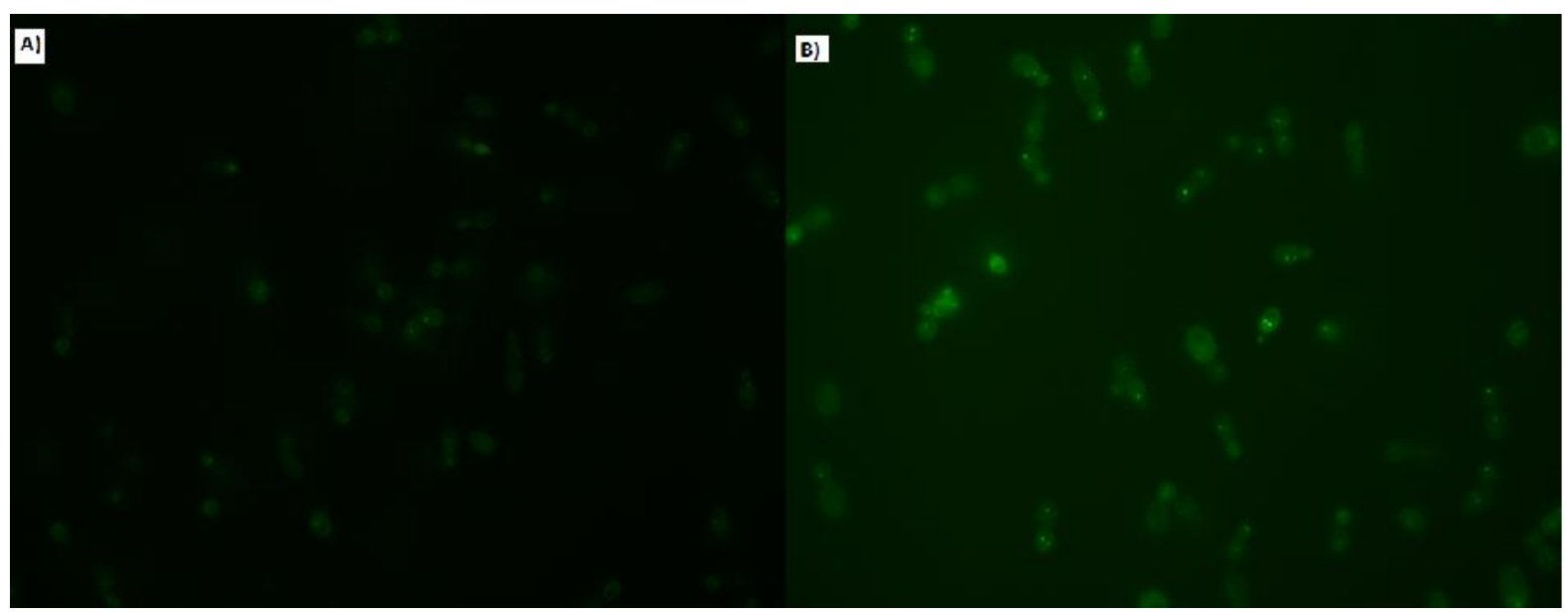

Figura 19 - A) Yarrowia lipolytica IMUFRJ 50682 cultivada em meio YNB por $24 \mathrm{~h}$ e fixada com formaldeído, B) Yarrowia lipolytica IMUFRJ 50682 cultivada em meio YNB por $24 \mathrm{~h}$ sem fixação. 
As análises de imagem sobre as PLs registradas por microscopia foram feitas com o software ImageJ (desenvolvido por National Institutes of Health) e os dados apresentados na Tabela 7.

Tabela 7 - Quantificação de partículas lipídicas por análise de imagem nas leveduras S. cerevisiae BY4741 e Yarrowia lipolytica IMUFRJ 50682.

\begin{tabular}{ccc}
\hline & $\begin{array}{c}\text { S. cerevisiae } \\
\text { BY4741 }\end{array}$ & $\begin{array}{c}\text { Yarrowia lipolytica } \\
\text { IMUFRJ 50682 }^{(\mathrm{b})}\end{array}$ \\
\hline Número de PLs analisadas & 52 & 50 \\
Número de células & 45 & 67 \\
Área de fluorescência & 4227 pixels & 1621 pixels \\
Fluorescência por célula & 94 pixels/célula & 24 pixels/célula \\
PLs por célula & 1,16 PL/Célula & 0,75 PL/Célula \\
\hline
\end{tabular}

(a) S. cerevisiae BY4741 fixada em $4 \mathrm{~h}$ de cultivo em meio YPD

(b) Yarrowia lipolytica IMUFRJ 50682 cultivada em meio YNB por $24 \mathrm{~h}$ sem fixação (Fig. 18B)

Observa-se um maior número de PLs por célula em $S$. cerevisiae BY4741 quando comparado à $Y$. lipolytica IMUFRJ 50682, 1,16 e 0,75 respectivamente, e maior área de fluorescência por célula em $S$. cerevisiae do que em $Y$. lipolytica, 93,93 e 24,19 (pixels/célula) respectivamente. Isto vai contra o que esperávamos, já que a levedura $Y$. lipolytica, ao contrário de $S$. cerevisiae, é conhecida por sua capacidade de acumular lipídios neutros na forma de PLs (Beopoulos et al., 2009 b). Uma possível explicação para esta aparente contradição é a levedura $Y$. lipolytica não se encontrar em condições ideais para o acúmulo de lipídios nas condições experimentais que foram empregadas para este estudo. Sabe-se que este acúmulo ocorre de maneira mais acentuada quando há falta de nitrogênio e excesso de fonte de carbono no meio de cultivo, pois durante o crescimento celular normal a proliferação da membrana citoplasmática é um importante destino para o pool de ésteres de esterol e de lipídios celulares, que acabam sendo desviados para esta finalidade, em vez de serem acumulados na forma de PLs. Quando a proliferação da membrana citoplasmática cessa, como ocorre durante a fase estacionária, ésteres de esteróis não podem ser hidrolisados e começam a se acumular, ocorrendo assim a expansão da população de PLs (Beopoulos et al., 2009a; Zweytick et al., 2000). Outra hipótese, para a diferença nos resultados, seria as condições que cada levedura foi analisada, pois a levedura $S$. cerevisiae se encontrava em fase de 
crescimento exponencial e foi cultivada em meio complexo YPD, com maior fonte de nutrientes, o que favoreceria o acúmulo de lipídios. Enquanto a levedura Y. lipolytica foi cultivada em meio definido YNB e foi amostrada no final do cultivo, consequentemente com baixa concentração de fonte de carbono e em fase estacionária de crescimento.

\subsubsection{Análise de PLs por fluorimetria}

Além das análises descritas acima, baseadas em microscopia de fluorescência e análise de imagens, foram também realizadas análises de fluorescência por fluometria. Estas análises foram realizadas segundo metodologia desenvolvida por Bozaquel-Morais (2010) (detalhes em materiais e métodos) e a leitura foi realizada com excitação em 485 nm e emissão em 510 nm, em um fluorômetro.

Esse método consiste no uso de um fluoróforo (BODIPY 493/503) em uma solução de iodeto de potássio, que é um supressor de fluorescência clássico, portanto um meio em que o fluoróforo não fluoresce. Adicionando-se células ao meio, o bodipy em solução penetra nas células e se desloca passivamente para as partículas lipídicas, não mais sofrendo ação do iodeto e, assim, fluorescendo. Deste modo, havendo bodipy em excesso, adições sucessivas de células causarão acréscimos na fluorescência lida. Conhecendo-se a quantidade de células adicionadas, é possível criar um gráfico da fluorescência medida contra a concentração de células no meio, obtendo-se assim uma curva cuja inclinação representará o nível médio de partículas lipídicas na amostra. Espera-se que quanto maior for o conteúdo de partículas lipídicas em determinada condição, maior será o aumento da fluorescência medida para uma mesma quantidade adicionada de células e, consequentemente, a inclinação da curva obtida será maior. Já no método anteriormente utilizado (item 5.4.2), a quantificação é feita através da área de fluorescência que é analisada através de um software de análise de imagem, que quantifica uma imagem em duas dimensões.

Os resultados das análises por fluorimetria (Figura 20) não apresentaram uma boa correlação com análises microscópicas para a levedura Yarrowia lipolytica IMUFRJ 50682. Uma possível causa é o tempo de exposição da célula ao 
formaldeído, pois, conforme foi constatado durante os testes com microscopia, o tratamento para fixação das células afetou a coloração das mesmas pelo BODIPY 493/503 (Figura 19). Portanto, é necessário adaptar a metodologia por microscopia de fluorescência anteriormente usada em Saccharomyces cerevisiae, para a levedura Y. lipolytica, estudando: menores tempos de exposição ao formaldeído para a fixação da Yarrowia lipolytica e até mesmo outros métodos de fixação. Outra possível causa para as diferenças observadas entre as duas metodologias seria a falta de experiência do experimentador, pois como pode ser observado na Figura 20, mesmo para a linhagem S. cerevisiae BY4741, a análise não apresentou uma boa reprodutibilidade. A fixação não é obrigatória para a análise por fluorimetria ou para a captura de imagens por microscopia, mas se torna necessária no caso de se possuir muitas amostras ou no caso da impossibilidade de se analisar as amostras de imediato, possibilitando assim o armazenamento das amostras em geladeira, para posterior análise.

Em função destes resultados e das dificuldades em se implementar estas análises de forma a se tornarem rotineiras em nosso laboratório na USP, decidiu-se por não dar continuidade às mesmas e priorizar a realização dos estudos em biorreator, bem como utilizar a microscopia de fluorescência, equipamento já disponível no laboratório, para análise das PLs.

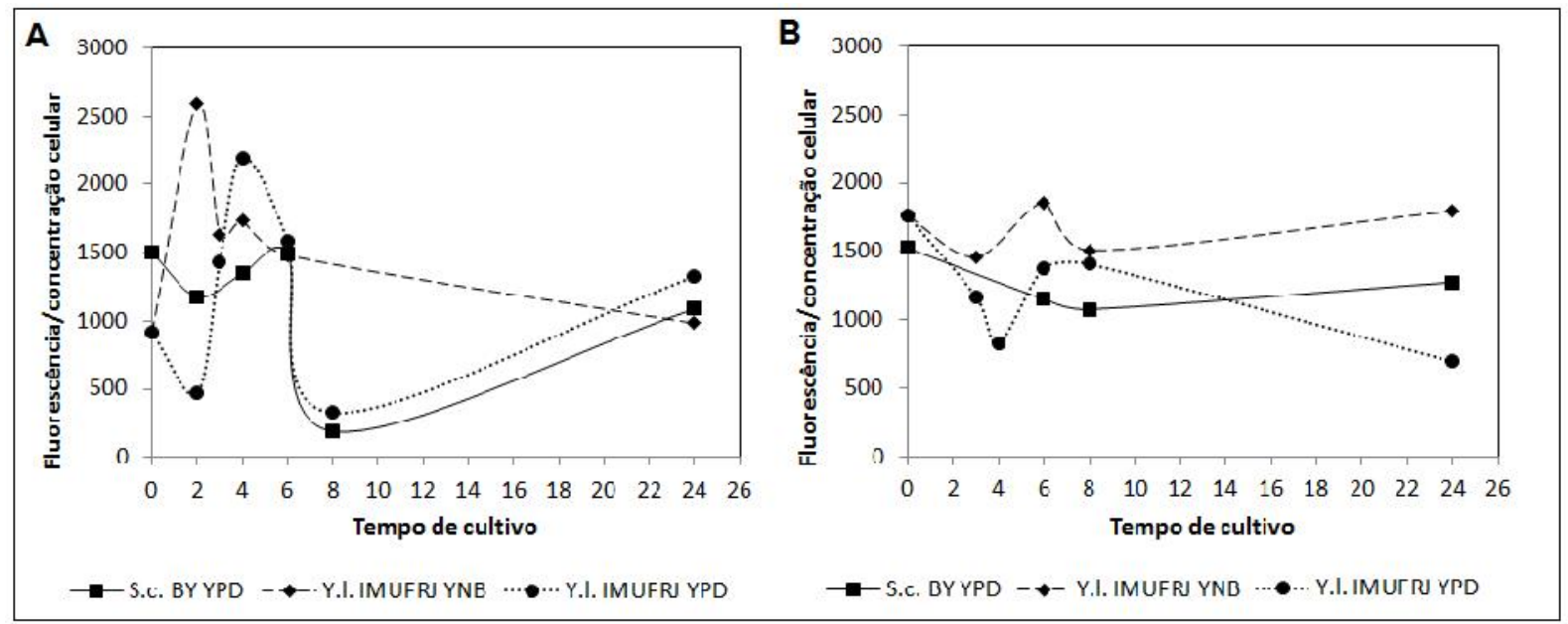

Figura 20 - Análise de fluorimetria. Utilizando o corante BODIPY 493/503, dos cultivos em frasco com a levedura $S$. cerevisiae BY4741 em meio YPD e da levedura Yarrowia lipolytica IMUFRJ 50682 em meio YPD e YNB, todos os cultivos com glicose $(20 \mathrm{~g} / \mathrm{L})$ como fonte de carbono, $28{ }^{\circ} \mathrm{C}$ e $250 \mathrm{rpm}$. A) Primeira análise de fluorimetria e B) Repetição da análise de fluorimetria. 


\subsection{ANÁLISE ELEMENTAR DA BIOMASSA DE Y. lipolytica}

Para estabelecer uma composição de meio de cultura com relação $\mathrm{C} / \mathrm{N}$ que leve à limitação nutricional por nitrogênio nos cultivos em quimiostato, foi realizada a análise elementar da biomassa da linhagem Y. lipolytica w29. Este tipo de informação também pode revelar diferenças importantes entre esta levedura e outras espécies. Finalmente, a análise elementar da biomassa amostrada de cultivos realizados em meio definido pode nos permitiu calcular algumas variáveis que não foram medidas, seja por que não há recursos para isto ou porque houve problemas com as medições realizadas.

As amostras de biomassa de $Y$. lipolytica analisadas para o teor de $\mathrm{C}, \mathrm{H}$ e N foram obtidas no final da fase exponencial de cultivos realizados em frasco agitado. Com estes dados e, assumindo-se um determinado teor de cinzas na biomassa e obtendo-se o teor de oxigênio por diferença, determinou-se uma fórmula molecular para a biomassa de $Y$. lipolytica w29 nas condições de cultivo empregadas (Tabela 8). Com estes dados, tentamos equacionar o crescimento da levedura em glicose, considerando os 4 elementos químicos mais abundantes na biomassa microbiana, da seguinte forma:

$1 \mathrm{C}_{6} \mathrm{H}_{12} \mathrm{O}_{6}+0,55 \mathrm{NH}_{3}+1,31 \mathrm{O}_{2} \rightarrow 4,24 \mathrm{CH}_{1,98} \mathrm{O}_{0,58} \mathrm{~N}_{0,13}+1,76 \mathrm{CO}_{2}+2,63 \mathrm{H}_{2} \mathrm{O}$

Segundo a equação acima, a cada $180 \mathrm{~g}$ de glicose consumida são formados 106,3 g de biomassa, indicando um $\mathrm{Y}_{\mathrm{x} / \mathrm{s}}$ teórico de 0,59 g DW/g glucose. Levando em conta uma conversão total de glicose a biomassa, é esperado um $\mathrm{Y}_{\mathrm{x} / \mathrm{s}}$ experimental 7\% menor que o valor teórico, pois no $Y_{\mathrm{x} / \mathrm{s}}$ teórico não são consideradas cinzas no cálculo.

Um valor de $\mathrm{Y}_{\mathrm{x} / \mathrm{s}}$ próximo ao $\mathrm{Y}_{\mathrm{x} / \mathrm{s}}$ teórico foi observado no cultivo em biorreator $(0,53 \mathrm{~g} \mathrm{DW} / \mathrm{g}$ glucose) e inferior ao observado no cultivo em frasco $(0,73 \mathrm{~g} \mathrm{DW} / \mathrm{g}$ glucose, Tabela 4), com a mesma linhagem. Esta é mais uma evidência de que este valor experimental em torno de 0,7 g DW/g glucose está incorreto.

Rywi'nska et al. (2006) estudaram a composição elementar da biomassa da linhagem $Y$. lipolytica A-101-1.31 em cultivo sem limitação nutricional e a porcentagem de carbono encontrada na biomassa foi de $47,14 \%$ e de nitrogênio de $7,28 \%$, valores semelhantes aos encontrados neste trabalho para a linhagem $Y$. 
lipolytica w29 (Tabela 8). Cescut (2009) calculou uma fórmula empírica da biomassa, em crescimento exponencial em meio definido com glicose, para a linhagem $Y$. lipolytica w29, que é diferente dos valores discutidos acima (Tabela 8).

Tabela 8 - Composição elementar da biomassa da levedura Y. lipolytica w29

\begin{tabular}{|c|c|c|c|c|c|c|c|c|c|c|}
\hline \multirow{2}{*}{ Levedura } & \multirow{2}{*}{ Referência } & \multicolumn{4}{|c|}{$\begin{array}{l}\text { Composição } \\
\text { elementar }\end{array}$} & \multirow{2}{*}{ 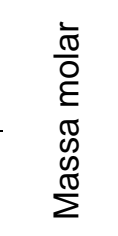 } & \multirow{2}{*}{$\% \mathrm{C}$} & \multirow{2}{*}{$\% \mathrm{~N}$} & \multirow{2}{*}{ 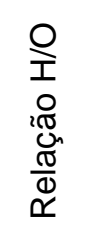 } & \multirow{2}{*}{ 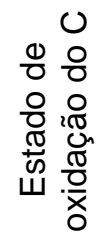 } \\
\hline & & C & $\mathrm{H}$ & $\mathrm{O}^{(\mathrm{C})}$ & N & & & & & \\
\hline Y. lipolytica w29 (a)(b) & Este trabalho & 1 & 1,98 & 0,58 & 0,13 & 25,08 & 48 & 7,1 & 3,41 & $-0,43$ \\
\hline Y. lipolytica w29 & Cescut (2009) & 1 & 1,74 & 0,45 & 0,13 & 23,44 & & & & $-0,45$ \\
\hline $\begin{array}{c}\text { Y.lipolytica A-101- } \\
1.31\end{array}$ & $\begin{array}{l}\text { Rywi'nska et al. } \\
\text { (2006) }\end{array}$ & 1 & 1,76 & 0,50 & 0,13 & 23,58 & 47 & 7,3 & 3,52 & $-0,37$ \\
\hline $\begin{array}{l}\text { D. bruxellensis } \\
\text { GDB248 }\end{array}$ & Leite et al. (2012) & 1 & 1,75 & 0,58 & 0,15 & 25,17 & 48 & 8,3 & 3,01 & $-0,15$ \\
\hline $\begin{array}{l}\text { D. bruxellensis } \\
\text { IHEM } 6037\end{array}$ & $\begin{array}{l}\text { Uscanga et al. } \\
\text { (2003) }\end{array}$ & 1 & 1,54 & 0,83 & 0,11 & 28,32 & 42 & 5,3 & 1,86 & $+0,45$ \\
\hline $\begin{array}{c}\text { S. cerevisiae } \\
\text { CEN.PK113-7D }\end{array}$ & $\begin{array}{l}\text { Lange e Heijnen } \\
\text { (2001) }\end{array}$ & 1 & 1,75 & 0,60 & 0,15 & 25,35 & 47 & 8,2 & 2,93 & $-0,10$ \\
\hline
\end{tabular}

A composição elementar da biomassa de $Y$. lipolytica w29 encontrada neste trabalho também é semelhante à composição da biomassa de outras leveduras, como S. cerevisiae CEN.PK113 -7D (Lange e Heijnen, 2001) e D. bruxellensis GDB248 (Leite et al., 2012) (Tabela 8). No entanto, o estado de oxidação médio do átomo de carbono na biomassa de $Y$. lipolytica indica que o carbono encontra-se mais reduzido nesta levedura, do que em $D$. bruxellensis ou em $S$. cerevisiae. Isto pode estar relacionado ao fato de $Y$. lipolytica acumular lipídios como forma de reserva energética. $O$ carbono em ácidos graxos e no glicerol encontra-se em estado mais reduzido que o carbono em carboidratos.

Através da equação 9 , também é possível concluir que uma relação $\mathrm{C} / \mathrm{N}$ superior a 9,35 no meio de cultura limitaria a fonte de nitrogênio no cultivo. 


\subsection{CINÉTICAS DE CRESCIMENTO DE Y. lipolytica EM BIORREATOR}

Como o objetivo original deste trabalho era correlacionar a velocidade específica de crescimento com a formação de PLs em Y. lipolytica, o que somente seria possível através da realização de cultivos em biorreator em modo de quimiostato, foram realizados cultivos preliminares em biorreator, em modo batelada, por serem mais simples do que os quimiostatos. Com isto, pretendia-se estabelecer um protocolo de cultivo para esta levedura em biorreator, uma vez que questões como agitação mecânica, aeração e controle de pH, além do monitoramento da concentração de oxigênio dissolvido, diferenciam esta forma de cultivo dos cultivos em frasco agitado realizados até então. Estes fatores são especialmente relevantes no caso da levedura $Y$. lipolytica, pois já havíamos observado que a formação de espuma tem papel importantíssimo nestes cultivos, podendo inclusive inviabilizá-los, já que as células desta levedura tendem, por exemplo, a deixar o meio líquido e migrar para a espuma, por causa de sua característica superfície hidrofóbica (Oliveira, 2014; Kim et al., 2000). Cabe também ressaltar que cultivos em biorreator permitem a obtenção de parâmetros fisiológicos de maneira mais quantitativa e reprodutível do que cultivos em frasco agitado, pelos motivos descritos acima. Inicialmente, foram realizados cultivos em reator no modo batelada com as linhagens $Y$. lipolytica IMUFRJ 50682 e w29, usando como fonte de carbono glicose e glicerol. Os dados são apresentados nas Figuras 21, 22 e 23.

Após o primeiro cultivo com a linhagem IMUFRJ 50682, com fonte de carbono glicose, a concentração inicial da fonte de carbono nos demais cultivos foi reduzida de 10 para $5 \mathrm{~g} / \mathrm{L}$; essa medida foi tomada com o intuito de reduzir o tempo de cultivo. Como apresentado no Apêndice B deste trabalho, em todos os cultivos a fonte de carbono foi completamente consumida e não foram detectados metabólitos extracelulares por cromatografia líquida (dados não apresentados), ao menos segundo a metodologia empregada neste trabalho (detalhes em Materiais e Métodos). As velocidades específicas máximas de crescimento apresentadas pelas linhagens IMUFRJ 50682 e w29, nos cultivos em biorreator com glicose foram 0,28 e $0,29 \mathrm{~h}^{-1}$, respectivamente, e nos cultivos com glicerol foram 0,34 e $0,37 \mathrm{~h}^{-1}$ respectivamente, como apresentado na Tabela 9. 


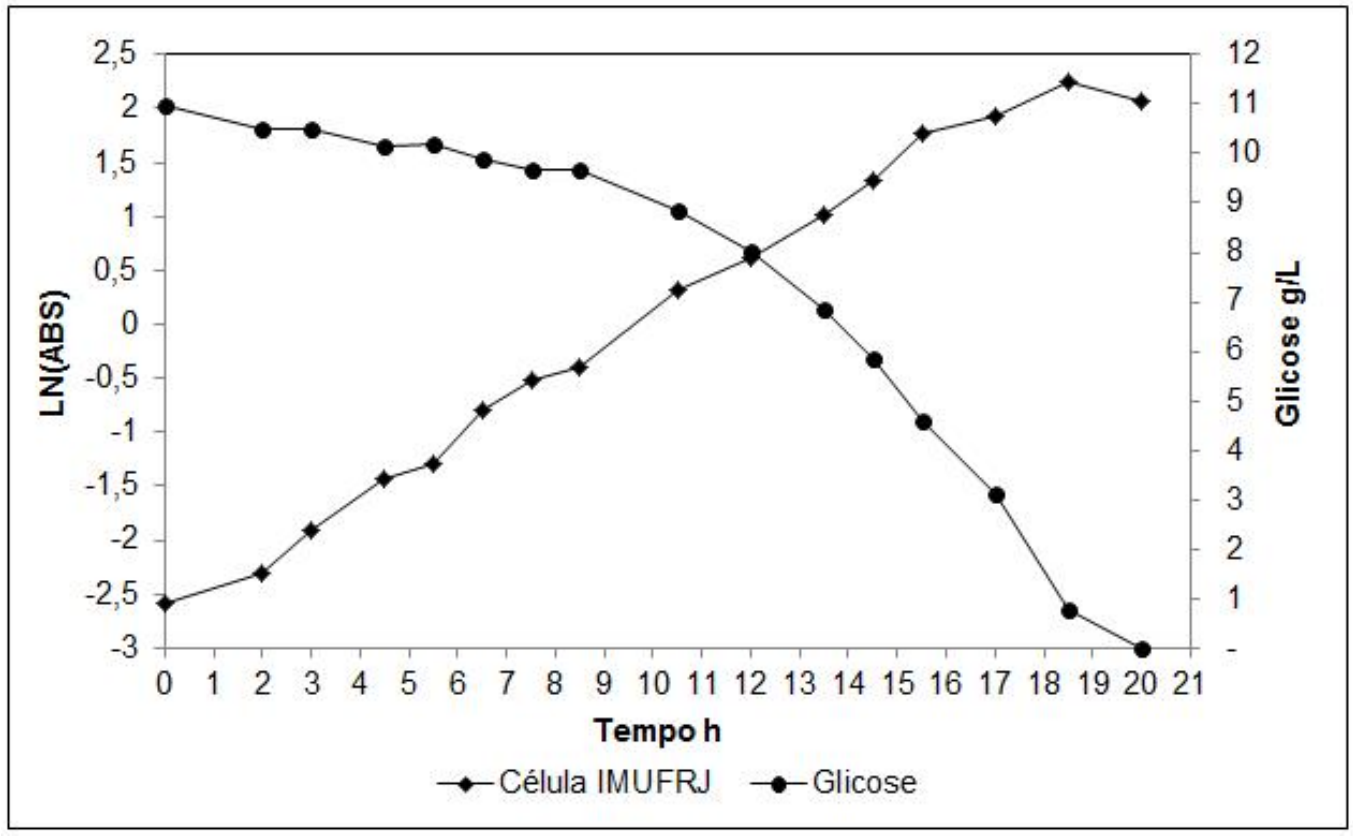

Figura 21 - Logaritmo natural da absorbância a $600 \mathrm{~nm}$ e concentração de glicose durante cultivo em batelada com a linhagem IMUFRJ 50682 em biorreator de $1 \mathrm{~L}, \mathbf{1 0} \mathrm{g} / \mathrm{L}$ iniciais de glicose iniciais, 28 ${ }^{\circ} \mathrm{C}, \mathrm{pH} 5$, agitação $1000 \mathrm{rpm}, 0,3 \mathrm{~mL} / \mathrm{L}$ de antiespumante e ar comprimido a $1 \mathrm{vvm}$. Relação $\mathrm{C} / \mathrm{N}(\mathrm{g} / \mathrm{g})$ inicial igual a 6,25.

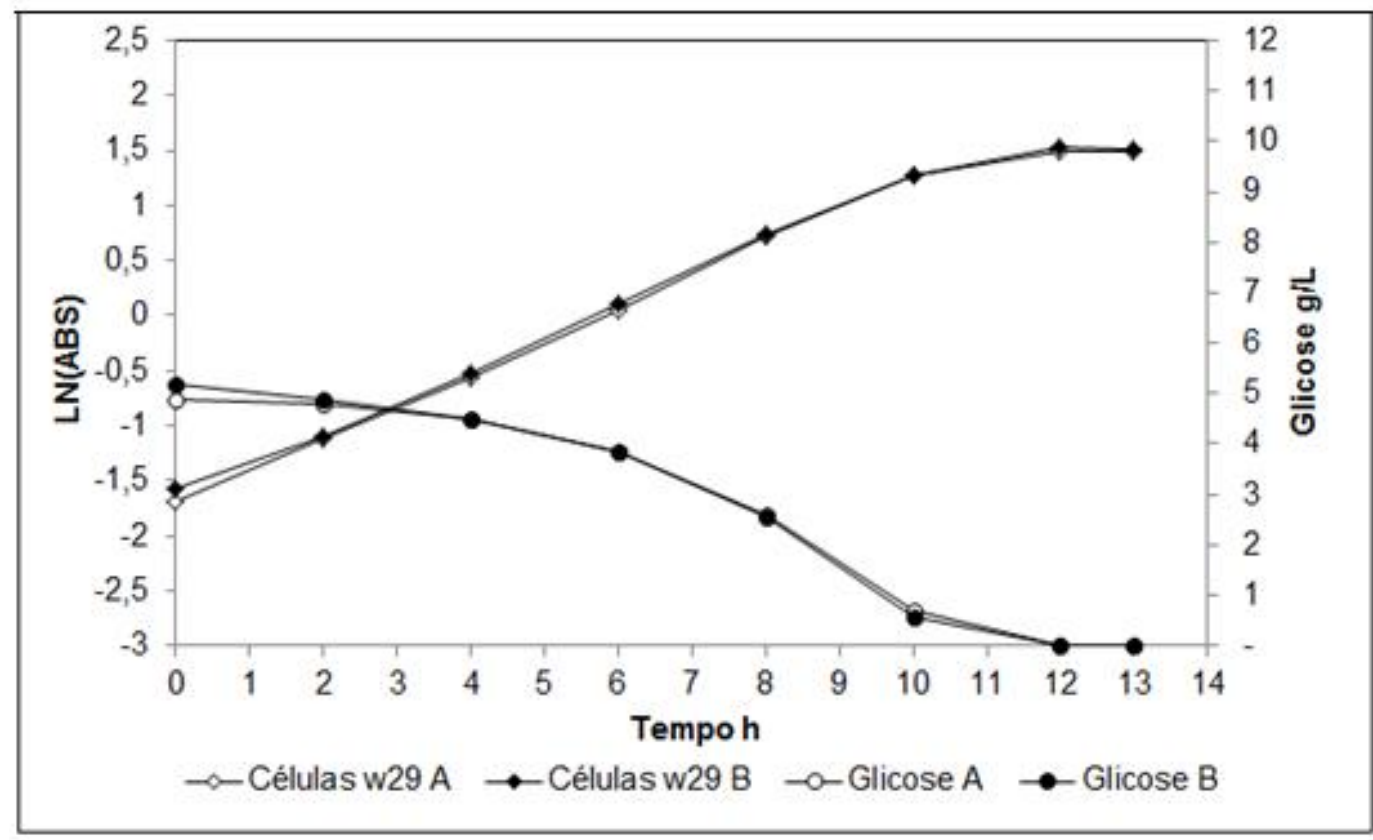

Figura 22 - Logaritmo natural da absorbância a $600 \mathrm{~nm}$ e concentração de glicose durante cultivo em batelada com a linhagem w29 em biorreator de $1 \mathrm{~L}, \mathbf{5} \mathbf{g} / \mathrm{L}$ iniciais de glicose iniciais, $28^{\circ} \mathrm{C}, \mathrm{pH} 5$, agitação $1000 \mathrm{rpm}, 0,3 \mathrm{~mL} / \mathrm{L}$ de antiespumante e ar comprimido a $1 \mathrm{vvm}$. Relação $\mathrm{C} / \mathrm{N}(\mathrm{g} / \mathrm{g})$ inicial igual a 3,13. São apresentados dados de uma duplicata experimental (A e B). 


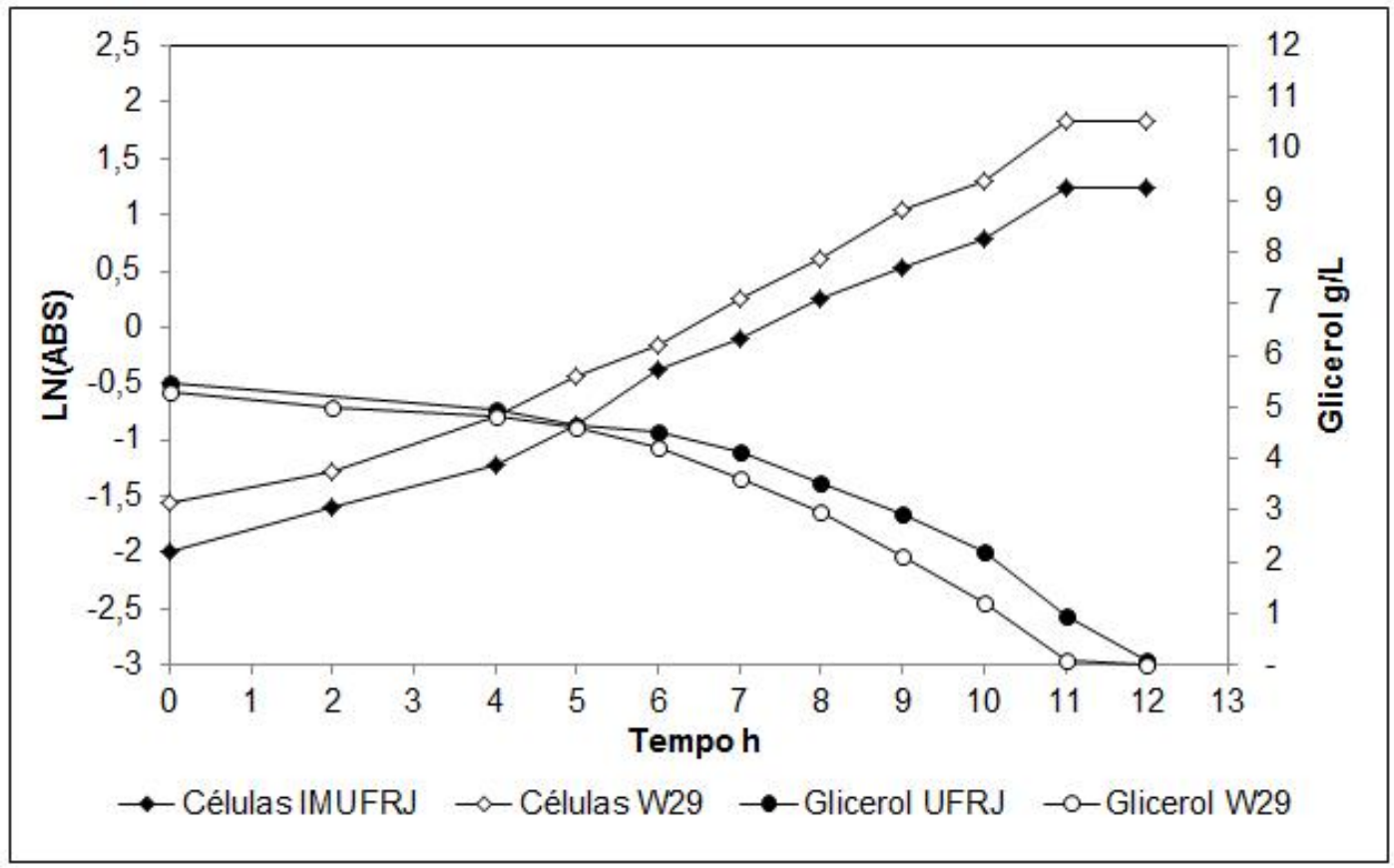

Figura 23 - Logaritmo natural da absorbância a $600 \mathrm{~nm}$ e concentração de glicerol durante cultivo em batelada em biorreator de $1 \mathrm{~L}$ com as linhagens IMUFRJ 50682 e w29, a $28{ }^{\circ} \mathrm{C}, \mathrm{pH}$ 5, agitação 1000 rpm, 0,3 $\mathrm{mL} / \mathrm{L}$ de antiespumante, ar comprimido a $1 \mathrm{vvm}$ e $\mathbf{5} \mathbf{g} / \mathbf{L}$ iniciais de glicerol como fonte de carbono. Relação C/N (g/g) inicial igual a 3,13.

Comparando-se estes dados com aqueles obtidos durante os cultivos realizados em frasco agitado (Tabela 4), observa-se que são próximos uns aos outros, considerando-se condições de cultivo análogas (as linhagens IMUFRJ 50682 e w29 apresentaram respectivamente as seguintes velocidades específicas máximas de crescimento durante os cultivos em frasco: 0,32 e 0,30 $\mathrm{h}^{-1}$ em fonte de carbono glicose, 0,36 e 0,34 $\mathrm{h}^{-1}$ em fonte de carbono glicerol).

Os valores de $Y_{X / S}$ apresentados pela linhagem IMUFRJ 50682 nos cultivos em biorreator foram 0,48 (g DW). (g glucose $)^{-1}$ e $0,55 \mathrm{~g}$ (g DW). (g glycerol) ${ }^{-1}$ (Tabela 9, cálculo indicado no Apêndice A deste trabalho). Comparando-se esses valores com os valores de $Y_{\mathrm{X} / \mathrm{S}}$ obtidos nos cultivos em frasco para a mesma linhagem (Tabela 4) $(0,49 \text { (g DW).(g glucose })^{-1}$ e 0,58 (g DW).(g glycerol $\left.)^{-1}\right)$, nota-se que os valores de $\mathrm{Y}_{\mathrm{X} / \mathrm{S}}$ em ambas as formas de cultivo são semelhantes.

Para a linhagem w29, os valores de $Y_{X / S}$ obtidos no presente trabalho nos cultivos em biorreator $(0,53 \text { (g DW).(g glucose })^{-1}$ e 0,59 (g DW).(g glycerol $\left.)^{-1}\right)$, foram próximos do valor de $\mathrm{Yx} / \mathrm{s}$ reportado na literatura para a mesma linhagem por Juszczyk et al. (2013) $\left.(0,56 \text { (g DW).(g glycerol })^{-1}\right)$. No entanto, esses valores foram inferiores aos valores observados nos cultivos em frasco $(0,73 \text { (g DW).(g glucose })^{-1} \mathrm{e}$ $0,71$ (g DW).(g glycerol $\left.)^{-1}\right)$, para ambos os substratos estudados. 
Uma hipótese para explicar o menor valor de $\mathrm{Y}_{\mathrm{X} / \mathrm{S}}$ observado nos cultivos em biorreator seria a superestimação dos valores de $\mathrm{Yx} / \mathrm{s}$ nos cultivos em frasco, devido a erros nas análises de ABS(600) ou HPLC. Outra hipótese seria o estresse causado pelo cisalhamento gerado pela agitação mecânica, pois, para evitar a formação de espuma no cultivo, foi utilizada uma agitação elevada (1000 rpm). Este fenômeno foi observado por Deive et al. (2010), que apresentaram uma diminuição na concentração máxima de biomassa com o aumento da agitação no cultivo da linhagem Yarrowia lipolytica CECT 1240 (ATCC 18942) em meio com 20 g/L de glicose e $10 \mathrm{~g} / \mathrm{L}$ de óleo de oliva, cerca de $15 \mathrm{~g} / \mathrm{L}$ de biomassa obtida a $400 \mathrm{rpm}$ e 3 g/L a $1000 \mathrm{rpm}$.

Tabela 9 - Parâmetros fisiológicos obtidos nos cultivos em biorreator, em modo batelada, para Y. lipolytica IMUFRJ 50682 e w29.

\begin{tabular}{cccccc}
\hline Linhagem & $\begin{array}{c}\text { Fonte } \\
\text { de } \\
\text { carbono }\end{array}$ & $\begin{array}{c}\text { Conc. inicial } \\
\text { da fonte de } \\
\text { carbono }(\mathrm{g} / \mathrm{L})\end{array}$ & $\mu_{\text {máx }}\left(\mathrm{h}^{-1}\right)$ & $\begin{array}{c}\mathrm{X}_{\mathrm{FINAL}} \\
(\mathrm{g} \mathrm{DW} / \mathrm{L})\end{array}$ & $\mathrm{Y}_{\mathrm{X} / \mathrm{s}}{ }^{(\mathrm{a})}$ \\
\hline Y. lipolytica & Glicose & 10 & 0,28 & 4,62 & 0,48 \\
IMUFRJ 50682 & Glicerol & 5,1 & 0,34 & 2,30 & 0,55 \\
\hline \multirow{2}{*}{ Y. lipolytica w29 } & Glicose & 5 & $0,29 \pm 0,00$ & $2,81 \pm 0,17$ & $0,53 \pm 0,01^{(\mathrm{b})}$ \\
& Glicerol & 5,1 & 0,37 & 3,05 & 0,59 \\
\hline
\end{tabular}

(a) Calculado na fase exponencial de crescimento

(b) Média e desvio da média do experimento realizado em duplicata.

Nos cultivos em biorreator, diferentemente dos cultivos em frasco, foram observados valores de $Y_{X / S}$ sempre maiores, quando a fonte de carbono era 0 glicerol, em relação à fonte de carbono glicose, para ambas as linhagens estudadas. Isto se deve muito provavelmente ao fato de haver mais energia-livre disponível na oxidação de glicerol a $\mathrm{CO}_{2}$ e $\mathrm{H}_{2} \mathrm{O}$, do que na oxidação de glicose aos mesmos compostos, conforme discutido no item 5.2.

Considerando-se todos os fatos acima e levando-se em conta que são raros ou inexistentes os dados de literatura reportando fatores de conversão de substrato a células (Yx/s) maiores que $0,6 \mathrm{~g} / \mathrm{g}$ em cultivos microbianos realizados em meios definidos, com fonte única de carbono, é muito provável que os valores em torno de $0,7 \mathrm{~g} / \mathrm{g}$ obtidos nos cultivos com a linhagem Y. lipolytica w29 em meio definido, obtidos no presente trabalho, estejam incorretos.

Devido a problemas ocorridos nas medidas da fração molar de oxigênio no gás de saída do biorreator, não foi possível realizar o balanço gasoso. 
Em resumo, esses cultivos permitiram confirmar os valores dos principais parâmetros fisiológicos apresentados por esta levedura, anteriormente obtidos a partir de cultivos em frasco agitado. Considerando-se que o fator de conversão de substrato a células ( $\mathrm{Y} x / \mathrm{s})$ foi maior para cultivos realizados com glicerol como fonte única de carbono, em relação ao uso da glicose, tudo indica que o glicerol tem grande potencial para ser usado como um substrato de baixo custo para o cultivo de Y. lipolytica em processos industriais.

\subsection{CULTIVOS EM MODO CONTÍNUO}

Através de cultivos em quimiostato pode-se impor uma determinada vazão específica de alimentação, controlando-se assim a velocidade específica de crescimento das células (Schmidell et al., 2001). Isto permite, por exemplo, estudar diferentes linhagens ou diferentes condições de cultivo para uma mesma linhagem, mantendo-se a mesma velocidade específica de crescimento em todos os casos.

Uma vez que a produção e o acúmulo de lipídios na levedura $Y$. lipolytica são muito influenciados pela velocidade específica de crescimento (Papanikolaou e Agellis,2002), cultivos em quimiostato permitiriam o estudo e a comparação da formação de PLs em Y. lipolytica, em diferentes linhagens e em diferentes velocidades específicas de crescimento, bastando para isto estabelecer diferentes vazões específicas. Este era o objetivo principal deste projeto de mestrado, sendo os outros resultados acessórios para esta avaliação final. Por isto, planejamos e executamos alguns cultivos em regime contínuo com diferentes vazões específicas $(D)$ e em limitação da fonte de nitrogênio ( $\mathrm{C} / \mathrm{N}$ igual a 126), para favorecer o acúmulo de lipídios. O experimento foi realizado em duplicata, para que pudéssemos ter alguma informação sobre a reprodutibilidade dos mesmos. Segundo nossa estratégia experimental inicial, após uma etapa inicial descontínua, seriam estudados diferentes estados estacionários, cada um a uma diferente vazão específica, num mesmo experimento, na seguinte sequência: 0,25;0,15;0,05 e 0,25 $\mathrm{h}^{-1}$. Em função de problemas operacionais, principalmente interrupções no fornecimento de energia elétrica, mesmo após várias tentativas de realização destes experimentos, não foi possível atingir todos os estados estacionários previstos. 
Somente os estados estacionários conduzidos às vazões específicas de 0,25 e 0,15 $\mathrm{h}^{-1}$ foram atingidos em duplicata (Figura 24).

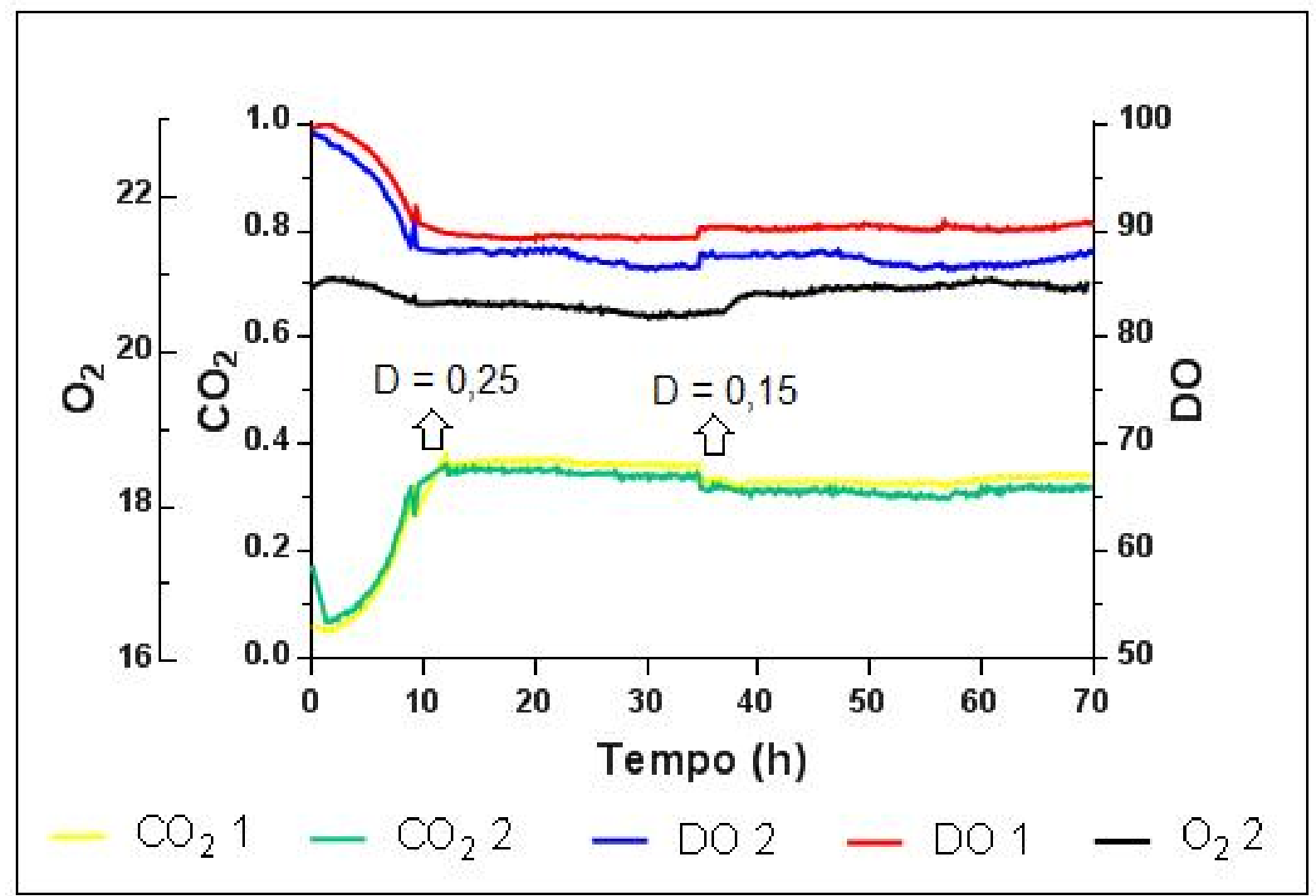

Figura 24 - Frações molares de $\mathrm{O}_{2}\left(\mathrm{O}_{2} 2\right)$ e $\mathrm{CO}_{2}\left(\mathrm{CO}_{2} 1\right.$ e $\mathrm{CO}_{2}$ 2) no gás de saída do biorreator e concentração de oxigênio dissolvido (DO) durante os cultivos contínuos realizados neste trabalho. São apresentados os dados de uma duplicata experimental (à exceção da variável fração molar de $\mathrm{O}_{2}$, para a qual somente há uma medida, dados em azul). Cultivos realizados com a linhagem $Y$. lipolytica IMUFRJ 50682, sob limitação da fonte de nitrogênio. Reator de $1 \mathrm{~L}, 28{ }^{\circ} \mathrm{C}, \mathrm{pH} 5,0$, agitação $1000 \mathrm{rpm}, 0,3 \mathrm{~mL} / \mathrm{L}$ de antiespumante, ar comprimido a 0,5 vvm, alimentação com $20 \mathrm{~g} / \mathrm{L}$ de glicerol como fonte de carbono e 0,3 $\mathrm{g} / \mathrm{L}$ de sulfato de amônio, relação $\mathrm{C} / \mathrm{N}(\mathrm{g} / \mathrm{g})$ igual a 126 . Início do cultivo em batelada, seguido por etapas contínuas com vazões específicas de 0,25 e $0,15 \quad h^{-1}$ respectivamente. Os instantes em que foram realizadas mudanças na vazão específica estão indicados com setas.

Através dos dados da fração molar de $\mathrm{CO}_{2}$ no gás de saída dos biorreatores e da concentração celular (quantificada em termos da biomassa seca por volume de amostra) foram constatados os estados-estacionários de quimiostato limitado por nitrogênio e foram calculados os principais parâmetros fisiológicos da linhagem $Y$. lipolytica IMUFRJ 50682 nestas condições (Tabela 10). Nenhum metabólito extracelular foi detectado pela metodologia de HPLC empregada neste trabalho, em nenhuma das condições estudadas (dados não apresentados). 
Devido à levedura Y. lipolytica IMUFRJ 50682 possuir um metabolismo totalmente respiratório, era esperado um coeficiente respiratório $(R Q$; relação entre as velocidades específicas de produção de $\mathrm{CO}_{2}$ e de consumo de $\mathrm{O}_{2}$ ) em torno de 0,85 (a fonte de carbono foi o glicerol). No entanto, os valores observados foram inferiores, 0,78 e 0,67 pra as vazões 0,25 e 0,15 $\mathrm{h}^{-1}$ respectivamente. Estas diferenças se devem provavelmente a erros na análise de gases, possivelmente decorrentes do fato de a calibração do equipamento ser feita com gases sem umidade, diferentemente do gás que deixa o biorreator, que carrega uma certa quantidade de água, que por sua vez pode não ter sido totalmente retida no frasco com sílica empregado à montante do analisador de gases.

Tabela 10 - Parâmetros fisiológicos calculados a partir do cultivo em quimiostato em diferentes vazões de alimentação.

\begin{tabular}{|c|c|c|}
\hline$D\left(\mathrm{~h}^{-1}\right)$ & 0,25 & 0,15 \\
\hline$X\left[g\right.$ DW. $\left.L^{-1}\right]$ & $0,90 \pm 0,02$ & $1,16 \pm 0,12$ \\
\hline $\mathrm{Y}_{\mathrm{X} / \mathrm{NH} 4}\left[(\mathrm{~g} \mathrm{DW}) \cdot\left(\mathrm{g} \mathrm{NH}_{4}\right)^{-1}\right]$ & $13,13 \pm 0,36$ & $13,02 \pm 0,75$ \\
\hline$Y_{X / \text { glicerol }}\left[(g\right.$ DW $) .\left(\right.$ g glycerol $\left.^{-1}\right]$ & $0,23 \pm 0,01$ & $0,55 \pm 0,12$ \\
\hline $\mathrm{q}_{\mathrm{s}(\mathrm{NH} 4)}\left[\left(\mathrm{mmol} \mathrm{NH}_{4}\right) \cdot(\mathrm{g}\right.$ DW.h $\left.)\right]$ & $1,07 \pm 0,01$ & $0,63 \pm 0,04$ \\
\hline $\mathrm{q}_{\mathrm{s}(\mathrm{glicerol})}\left[(\mathrm{mmol}\right.$ glycerol $\left.) .(\mathrm{g} D W \cdot h)^{-1}\right]$ & $12,20 \pm 0,40$ & $3,10 \pm 0,60$ \\
\hline $\mathrm{S}_{\text {residual }}\left[\mathrm{mg} \mathrm{NH} \mathrm{NH}_{4} \cdot \mathrm{L}^{-1}\right]$ & $0,40 \pm 0,02$ & $0,32 \pm 0,02$ \\
\hline$K_{\mathrm{s}}\left[\mathrm{mg} \mathrm{NH}_{4} \cdot \mathrm{L}^{-1}\right]$ & $0,13 \pm 0,00$ & $0,44 \pm 0,06$ \\
\hline $\mathrm{q}_{\mathrm{o} 2}\left[\left(\mathrm{mmol} \mathrm{O} \mathrm{O}_{2}\right) \cdot(\mathrm{g} \mathrm{DW} \cdot \mathrm{h})^{-1}\right]$ & 6,14 & 2,24 \\
\hline $\mathrm{qco}\left[\left(\mathrm{mmol} \mathrm{CO}_{2}\right) \cdot(\mathrm{g} \mathrm{DW} \cdot \mathrm{h})^{-1}\right]$ & 4,79 & 3,34 \\
\hline$R Q$ & 0,78 & 0,67 \\
\hline$Y_{x / s}$ true $\left[(g D W) \cdot\left(g_{\text {glycerol }}\right)^{-1}\right]$ & \multicolumn{2}{|c|}{0,12} \\
\hline $\mathrm{m}_{\mathrm{s}}\left[(\mathrm{g}\right.$ glycerol $\left.) \cdot(\mathrm{g} \text { DW.h })^{-1}\right]$ & \multicolumn{2}{|c|}{$-0,91$} \\
\hline
\end{tabular}

* Valores representam a média e o desvio da média dos experimentos realizados em duplicata. Para algumas variáveis, somente foi possível obter uma medida.

Apesar do aumento da concentração celular na taxa de diluição $0,15 \mathrm{~h}^{-1}(1,16$ g DW. $\left.\mathrm{L}^{-1}\right)$, quando comparada à taxa de diluição $0,25 \mathrm{~h}^{-1}\left(0,90 \mathrm{~g} \mathrm{DW} . \mathrm{L}^{-1}\right)$, houve uma diminuição nas velocidades específicas de produção de $\mathrm{CO}_{2}\left(q_{\mathrm{co} 2}\right)$ e de consumo de $\mathrm{O}_{2}$ (9o2), como observado na Figura 24 e na Tabela 10. Isso é provavelmente devido a um desaceleramento do metabolismo celular concomitantemente à diminuição da velocidade específica de crescimento. Isto também se reflete na redução da 
velocidade específica de consumo de glicerol ( $\left.\mathrm{q}_{\mathrm{s}(\mathrm{glicerol})}\right)$ de 12,2 (mmol glycerol).(g DW.h $)^{-1}$ à taxa de diluição $0,25 \mathrm{~h}^{-1}$ para 3,1 (mmol glycerol).(g DW.h $)^{-1}$ à taxa de diluição $0,15 \mathrm{~h}^{-1}$. Observou-se ainda uma alteração do $Y_{\text {X/glicerol de }}$ 0,23 (g DW).(g glycerol $)^{-1}$ na taxa de diluição $0,25 \mathrm{~h}^{-1}$ para 0,55 (g DW).(g glycerol) ${ }^{-1}$ na taxa de diluição $0,15 h^{-1}$. Em outros estudos, foram observadas mudanças notáveis de rendimentos totais de biomassa em função do $D$ (Gill et al., 1977; Brown et al., 1989). No entanto, essa alteração no fator de conversão substrato a células não foi observada por Papanikolaou e Agellis (2002) nos $D$ testados, apesar da mudança nos produtos de fermentação, indicando a presença de mecanismos reguladores que particionam o fluxo de carbono no sentido de lipídios, material de síntese não lipídico e requerimentos de energia.

A desaceleração do metabolismo celular pode também ser 0 fator responsável pela diminuição do coeficiente respiratório na taxa de diluição $0,15 \mathrm{~h}^{-1}$, uma vez que, através da análise do oxigênio dissolvido no meio, é possível afirmar que não houve limitação de oxigênio no cultivo, pois as medidas de DO ficaram em torno de $88 \%$ em ambos os estados estacionários atingidos.

Utilizando o conceito introduzido por Pirt (1975), o coeficiente de manutenção celular pode ser estimado a partir do gráfico $\mathrm{q}_{\mathrm{s}(\text { glicerol) }} v s$, já que o glicerol foi a única fonte de energia para $Y$. lipolytica nos cultivos realizados. Foram plotados no gráfico os dados referentes aos estados estacionários do cultivo contínuo e, com isto, foi obtido um coeficiente de manutenção $\left(m_{\mathrm{S}}\right)$ igual a $-0,91$ (g glycerol).(g DW.h $)^{-1}$. Porém, o valor esperado seria um valor positivo, indicando a parcela da energia, proveniente do consumo do substrato, destinada à manutenção das funções vitais do microrganismo (ou aos processos celulares diferentes da biossíntese). Também encontramos um $Y_{x / s}^{\text {true }}$ igual a 0,12 (g DW).(g glycerol) $)^{-1}$, um valor inferior ao

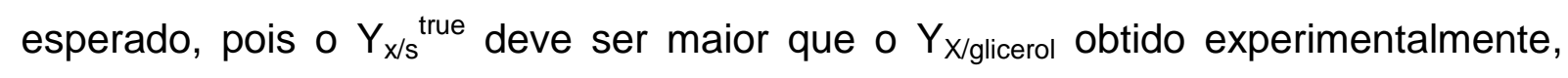
uma vez que esse cálculo não considera o coeficiente de manutenção celular. A melhor explicação que pudemos encontrar para estes valores inconsistentes de $m_{S} e$ $Y_{X / S}^{\text {true }}$ são erros experimentais, provavelmente na determinação analítica da concentração de glicerol, no meio de alimentação e/ou dentro do biorreator. Como houve pequeno consumo de glicerol nos cultivos, qualquer diferença nestes valores provocará uma grande diferença no valor calculado de qs(glicerol).

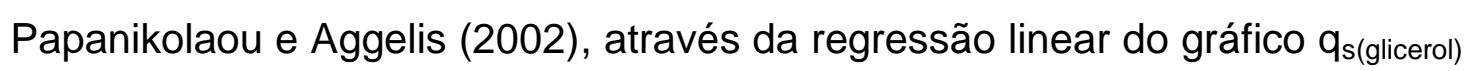
vs , calcularam um $Y_{X / S}{ }^{\text {true }}$ igual a 0,27 (g DW).(g glycerol $)^{-1}$ e um $m_{S}$ igual a 0,034 
(g glycerol).(g DW.h) ${ }^{-1}$ para a linhagem Y. lipolytica LGAM S(7)1 em cultivo utilizando glicerol industrial como fonte de carbono. Esses resultados são mais um indício de que os valores de $Y_{X / S}{ }^{\text {true }}$ e $m_{S}$ encontrados neste trabalho estão incorretos devido a possíveis erros experimentais, e provavelmente a levedura $Y$. lipolytica pode seguir o modelo introduzido por Pirt (1975).

Os valores de $Y_{\mathrm{X} / \mathrm{NH} 4}$ foram iguais em ambas as taxas de diluição estudadas, no entanto o $\mathrm{Y}_{\mathrm{X} / \mathrm{NH} 4}$ observado $\left(13,1(\mathrm{~g} \mathrm{DW}) .\left(\mathrm{g} \mathrm{NH}_{4}\right)^{-1}\right)$ foi menor do que o observado por Papanikolaou et al. (2006) $\left(40,1(\mathrm{~g} \mathrm{DW}) \cdot\left(\mathrm{g} \mathrm{NH}_{4}\right)^{-1}\right)$ em cultivo em frasco para a linhagem $Y$. lipolytica LGAM S(7) e glicose como fonte de carbono.

Observou-se uma redução no $\mathrm{q}_{\mathrm{s}(\mathrm{NH} 4)}$ com a redução na taxa de diluição do cultivo, de 1,07 para $0,63\left(\mathrm{mmol} \mathrm{NH}_{4}\right)$. (g DW.h), isso é devido a maior concentração de células e menor fornecimento de nitrogênio no cultivo na taxa de diluição igual a $0,15 \mathrm{~h}^{-1}$.

Houve um aumento do $K$ s na taxa de diluição igual a $0,15 \mathrm{~h}^{-1}$ e a diminuição do $S_{\text {residual }}$ no meio de cultura de $0,40 \mathrm{mg} \mathrm{NH}_{4} \cdot \mathrm{L}^{-1}\left(D=0,25 \mathrm{~h}^{-1}\right)$ para $0,32 \mathrm{mg} \mathrm{NH}_{4} \cdot \mathrm{L}^{-1}$ $\left(D=0,15 \mathrm{~h}^{-1}\right)$. O esperado seria um $K \mathrm{~s}$ igual nas duas taxas de diluição, no caso da levedura não possuir um sistema de transporte de amônio de alta afinidade para baixa disponibilidade do substrato. No caso de possuir um sistema de transporte de alta afinidade seria esperada uma diminuição no valor de $K_{\mathrm{s}}$, como descrito por Ames (1964), que relatou dois diferentes valores de $K_{\mathrm{s}}$ para Salmonella typhimurium (dependendo da concentração dos aminoácidos no meio), correspondentes a dois sistemas para a captação de aminoácidos específicos: uma permease para cada aminoácido aromático com elevada afinidade $\left(10^{-7} \mathrm{M}\right)$ e uma permease inespecífica com baixa afinidade $\left(10^{-5} \mathrm{M}\right)$.

Como apresentado na Tabela 11, não foram observadas diferenças significativas, nas taxas de diluição estudadas, no número de partículas lipídicas por célula ou um aumento da área das partículas lipídicas. Como observado por Papanikolaou e Aggelis (2002), para iniciar um aumento no acúmulo de lipídios na levedura, é necessário um $D$ inferior a $0,06 \mathrm{~h}^{-1}$. Acima dessa velocidade específica de crescimento, as leveduras acumulam menores quantidades de lipídios, pois a produção dessas moléculas se destina ao crescimento e à formação das membranas celulares. No entanto, a tendência dos dados obtidos no presente trabalho, apesar de não haver diferenças significativas, segue aquilo que se esperava, ou seja, um aumento no acúmulo de lipídios com a diminuição da 
velocidade específica de crescimento, conforme já reportado por Papanikolaou e Aggelis (2002), Ykema et al. (1986) e Ratledge (1994). Observa-se também um aumento no número de partículas lipídicas por célula com a diminuição da velocidade específica de crescimento, no cultivo em frasco agitado a linhagem $Y$. lipolytica IMUFRJ 50682, sem limitação nutricional, apresentou 0,75 PL/Célula (Tabela 7), no cultivo em quimiostato observou-se 1,91 PL/Célula $\left(D=0,25 \mathrm{~h}^{-1}\right) \mathrm{e}$ 2,27 PL/Célula $\left(D=0,15 \mathrm{~h}^{-1}\right)$, como indicado na Tabela 11.

Tabela 11 - Análise das partículas lipídicas nos diferentes estados estacionários do cultivo em quimiostato.

\begin{tabular}{lcc}
\hline$D$ & 0,25 & 0,15 \\
\hline Área de PL/Célula ( $\mathrm{m}^{2} /$ Célula) & $11,00 \pm 1,13$ & $14,12 \pm 2,76$ \\
PL/Célula (un/un) & $1,91 \pm 0,06$ & $2,27 \pm 0,38$ \\
\hline
\end{tabular}

\footnotetext{
"Valores indicam a média e o desvio da média dos experimentos realizados em duplicata.

** Parâmetros obtidos por microscopia de fluorescência através da análise de imagem.
}

As amostras de biomassa de levedura retiradas do biorreator em estado estacionário foram encaminhadas para análise da composição elementar da biomassa, analogamente ao realizado anteriormente para alguns cultivos em frasco (item 5.5). $\mathrm{O}$ objetivo foi quantificar a porcentagem dos elementos $\mathrm{C}, \mathrm{H}$ e $\mathrm{N}$ nas células de $Y$. lipolytica IMUFRJ 50682, nas diferentes condições experimentais empregadas. Através desta análise (Tabela 12), é possível observar que houve um ajuste na composição da biomassa da levedura, conforme a velocidade específica de crescimento. No cultivo com menor vazão de alimentação $\left(0,15 \mathrm{~h}^{-1}\right)$, houve uma diminuição na porcentagem de nitrogênio na biomassa, de 6,3 para $4,6 \%$, ou seja uma redução de $27 \%$ de nitrogênio na biomassa. É sabido que em leveduras o teor de proteína na biomassa celular aumenta com o aumento da velocidade específica de crescimento e isto explica este resultado (Hoek et al., 1998). O dado obtido nos cultivos em frasco, em que as células crescem com $\mu_{\text {Máx, }}$ corroboram esta tendência, pois são aqueles em que a biomassa celular tem maior teor de nitrogênio (Tabela 12). O mesmo foi observado por Rywi'nska et al. (2006), que estudaram a composição elementar da biomassa da linhagem Y.lipolytica A-101-1.31 com e sem restrição de macronutrientes no meio, no cultivo sob limitação de nitrogênio no meio de cultura observaram uma distinta modificação na composição elementar da 
biomassa, que apresentou uma concentração de nitrogênio 54,5\% menor em comparação ao cultivo sem restrição de nitrogênio.

Tabela 12 - Análise elementar da biomassa celular dos cultivos em quimostato em diferentes velocidades específicas de crescimento

\begin{tabular}{|c|c|c|c|c|c|c|c|c|c|c|}
\hline \multirow{2}{*}{ Yeast } & \multirow{2}{*}{$D\left(\mathrm{~h}^{-1}\right)$} & \multicolumn{4}{|c|}{ Composição elementar } & \multirow{2}{*}{$\begin{array}{l}\text { Massa } \\
\text { molar }\end{array}$} & \multirow{2}{*}{$\% \mathrm{C}$} & \multirow{2}{*}{$\% \mathrm{~N}$} & \multirow{2}{*}{$\begin{array}{c}\text { Relação } \\
\text { H/O }\end{array}$} & \multirow{2}{*}{ 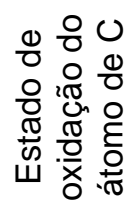 } \\
\hline & & C & $\mathrm{H}$ & $\mathrm{O}^{(\mathrm{e})}$ & N & & & & & \\
\hline Y. lipolytica & 0,25 & 1 & 2,04 & 0,82 & 0,13 & 28,98 & 41 & 6,3 & 2,49 & $-0,01$ \\
\hline IMUFRJ $50682^{(b)}$ & 0,15 & 1 & 2,34 & 0,91 & 0,10 & 30,30 & 40 & 4,6 & 2,57 & $-0,22$ \\
\hline $\begin{array}{l}\text { Y. lipolytica w29 } \\
\text { (a)(b) }\end{array}$ & - & 1 & 1,98 & 0,58 & 0,13 & 25,08 & 48 & 7,3 & 3,41 & $-0,43$ \\
\hline Y.lipolytica A- & $-($ (t) & 1 & 1,76 & 0,50 & 0,13 & 23,58 & 51 & 7,7 & 3,52 & $-0,37$ \\
\hline $101-1.31^{(\mathrm{c})}$ & - (g) & 1 & 1,83 & 0,58 & 0,06 & 23,95 & 50 & 3,5 & 3,15 & $-0,49$ \\
\hline $\begin{array}{c}\text { Y.lipolytica } \\
\text { AWG7 }^{\text {d) }}\end{array}$ & 0,009 & 1 & 2,14 & 0,51 & 0,08 & 23,42 & 51 & 4,8 & 4,19 & $-0,88$ \\
\hline
\end{tabular}

(a) Cultivo em frasco com $10 \mathrm{~g} / \mathrm{L}$ de glicose e $1,5 \mathrm{~g} / \mathrm{L}$ de fonte de nitrogênio, amostra retirada no final do cultivo sem ter ocorrido limitação nutricional.

(b) Composição elementar calculada considerando 7\% de cinza.

(c) Cultivo em frasco usando como fonte de carbono glicose com e sem limitação de fonte de nitrogênio, considerando 8\% de cinzas (Rywi'nska et al., 2006)

(d) Cultivo em quimiostato com limitação de nitrogênio usando como fonte de carbono glicerol (Rywi'nska et al., 2011).

(e) O teor de oxigênio foi calculado pela diferença entre a massa total da biomassa e a massa de C, $\mathrm{H}, \mathrm{N}$ e cinzas que foi medida.

(f) Meio sem limitação de nutrientes

(g) Meio com limitação de nitrogênio.

Rywi'nska et al. (2011) estudaram a composição elementar da linhagem Wratislavia AWG7 em diferentes taxas de diluição $0,009-0,031 \mathrm{~h}^{-1}$ e observaram um aumento na concentração de proteínas na biomassa de 26,3-41,3 \% ( $\mathrm{g} / \mathrm{g})$ de acordo com o aumento da taxas de diluição, também apresentaram uma composição elementar sob restrição de nitrogênio da linhagem Y.lipolytica A-101-1.31 próxima da observada nesse trabalho (Tabela 12).

Um resultado contraditório obtido foi um grau de redução maior para o átomo de carbono na biomassa da levedura cultivada em frasco $(-0,43$, Tabela 8$)$, em relação às leveduras cultivadas nos quimiostatos $(-0,01$ e $-0,22$ nas vazões específicas de 0,25 e 0,15 $\mathrm{h}^{-1}$, respectivamente). Como 0 teor de lipídios foi aparentemente maior nas leveduras cultivadas em quimiostato (ver dados das 
Tabelas 7 e 11), esperava-se o resultado contrário. Apesar de as linhagens usadas em ambos os sistemas terem sido diferentes (w29 e IMUFRJ 50582), não encontramos uma explicação adequada para explicar esta observação. 


\section{CONCLUSÕES}

Os cultivos realizados em frasco agitado permitiram:

1) escolher um meio de cultivo de composição totalmente definida, com tiamina como único fator de crescimento, adequado a estudos de fisiologia quantitativa com a levedura Yarrowia lipolytica;

2) verificar que $Y$. lipolytica não é capaz de crescer com sacarose ou xilose como única fonte de carbono;

3) verificar que as linhagens de $Y$. lipolytica IMUFRJ 50682 e w29 crescem com velocidade específica de crescimento máxima ( Máx) em torno de $0,49 \mathrm{~h}^{-1}$ num meio complexo contendo glicose, extrato de levedura e peptona (YPD), em torno de $0,31 \mathrm{~h}^{-1}$ em meio definido com glicose como única fonte de carbono e em torno de $0,35 \mathrm{~h}^{-1}$ no mesmo meio, mas com glicerol como única fonte de carbono, sem excreção de metabólitos para o meio de cultivo;

4) verificar que o uso de ureia, em vez de sulfato de amônio, como fonte de nitrogenio, contribui para uma variação menor do $\mathrm{pH}$ durante os cultivos, sem prejuízo ao crescimento da levedura;

5) Determinar a composição elementar da biomassa de $Y$. lipolytica $\left(\mathrm{CH}_{1,98} \mathrm{O}_{0,58} \mathrm{~N}_{0,13}\right)$, em que os átomos de carbono encontram-se em média mais reduzidos do que na biomassa de leveduras como Saccharomyces cerevisiae e Dekkera bruxellensis.

Os cultivos realizados em biorreator, em modo batelada, permitiram confirmar os valores dos principais parâmetros fisiológicos apresentados por esta levedura, anteriormente obtidos a partir de cultivos em frasco. O fator de conversão de substrato a células $(\mathrm{Yx} / \mathrm{s})$ foi maior para cultivos realizados com glicerol como fonte única de carbono (0,53 g/g para a linhagem IMUFRJ 50682), do que com glicose (0,48 g/g para a mesma linhagem).

Finalmente, cultivos realizados em quimiostato com glicerol como fonte de carbono e energia, limitados por amônio (fonte de nitrogênio, relação $C / N 126$ ), às vazões específicas de $0,25 \mathrm{~h}^{-1}$ e $0,15 \mathrm{~h}^{-1}$, permitiram observar que:

1) houve um ajuste na composição da biomassa da levedura, sendo observada uma diminuição no teor de nitrogênio quando a velocidade especifica de crescimento foi diminuída de 0,25 para $0,15 \mathrm{~h}^{-1}$; 
2) Nas vazões específicas estudadas $\left(0,25\right.$ e $\left.0,15 h^{-1}\right)$ não houve alteração significativa no número ou no tamanho das partículas lipídicas nas células de $Y$. lipolytica.

Em relação aos objetivos que haviam sido originalmente propostos para este trabalho, não foi possível:

1) implementar uma rotina para a análise de partículas lipídicas por microscopia de fluorescência e análise de imagem em $Y$. lipolytica, que não dependesse de um processamento imediato das amostras (a etapa de fixação de células requer mais estudos);

2) avaliar a formação de partículas lipídicas em $Y$. lipolytica a diferentes velocidades específicas de crescimento (problemas constantes de falta de energia elétrica impediram que os quimiostatos necessários fossem realizados). 


\section{SUGESTÕES PARA TRABALHOS FUTUROS}

A partir dos resultados e das conclusões deste trabalho, sugere-se:

- Cultivar ambas as linhagens de Y. lipolytica em quimiostato, com taxas de diluição inferiores a $0,06 \mathrm{~h}^{-1}$ para observar o acúmulo de lipídios nessas linhagens

- Estudar a composição dos lipídeos acumulados nas células de Y. lipolytica IMUFRJ 50682 e w29

- Deletar os genes que codificam seipin ou CTP: fosfocolina citidil transferase na linhagem IMUFRJ 50682 para induzir e estudar um possível maior acúmulo lipídico (Yang, et al., 2012). 


\section{REFERÊNCIAS}

AMARAL, P. F. F. Produção de lipase de Yarrowia lipolytica em biorreator multifásico. 2007, 221 p. Tese ( Doutorado em Tecnologia de Processos Químicos e Bioquímicos) Escola de Química da Universidade Federal do Rio De Janeiro, Rio de Janeiro, 2007.

AMES, G. F. Uptake of amino acids by Salmonella typhimurium. Arch. Biochem. Biophys. v. 104, p.1-18, 1964.

ATHENSTAEDT, K.; DAUM, G. The life cycle of neutral lipids: synthesis, storage and degradation. Cell. Mol. Life Sci, v.63, p. 1355-1369. 2006.

ATHENSTAEDT, K.;JOLIVET, P.;BOULARD, C.;ZIVY, M.;NEGRONI, L.;NICAUD, J. M.;CHARDOT, T. Lipid particle composition of the yeast Yarrowia lipolytica depends on the carbon source. Proteomics, v. 6, p.1450-1459, 2006.

BARNETT, J. A.; PAYNE, R. W.; YARROW, D. Yeasts: Characteristics and identification. Cambridge University Press, 2ed. New York, 1990.

BARTH, G.; GAILLARDIN, C. Yarrowia lipolytica. Nonconventional Yeasts in Biotechnology. ed. Wolf K, p. 313-388, Berlin, 1996.

BARTH, G.; GAILLARDIN, C. Physiology and genetics of the dimorphic fungus Yarrowia lipolytica. FEMS Microl. Rev., p. 1-19, 1997.

BASSO, T. O. Melhoramento da fermentação alcóolica em Saccharomyces cerevisiae por engenharia evolutiva. 2011, 136 p. Tese (Doutorado em Biotecnologia), Instituto de Ciências Biomédicas da Universidade de São Paulo. São Paulo. 2011.

BEOPOULOS, A.;MROZOVA, Z.;THEVENIEAU, F.; LE DALL, M-T.; HAPALA, I.; PAPANIKOLAOU, S.; CHARDOT , T.;NICAUD, J-M. Control of Lipid Accumulation in the Yeast Yarrowia lipolytica. Appl. Environ. Microbiol., v. 74, No. 24, p. 77797789, 2008.

BEOPOULOS, A.; CHARDOT, T.;NICAUD, J-M. Review: Yarrowia lipolytica: A model and a tool to understand the mechanism simplicated in lipid accumulation. Biochimie., v. 91 p. 692-696, 2009.(a)

BEOPOULOS, A.; CESCUT, J.; HADDOUCHE, R.;URIBELARREA, J-L.; MOLINAJOUVE, C.; NICAUD, J-M. Yarrowia lipolytica as a model for bio-oil production. Prog. lipid res., v.48 p. 375-387, 2009.(b)

BEOPOULOS, A.; NICAUD, J-M.; GAILLARDIN, C. An overview of lipid metabolism in yeasts and its impact on biotechnological processes. Appl. Microbiol. Biot., v. 90, p. 1193-1206, 2011. 
BEOPOULOS, A.; HADDOUCHE, R.;KABRAN, P.;DULERMO, T.;CHARDOT, T.;NICAUD, J-M. Identification and characterization of DGA2, an acyltransferase of the DGAT1 acyl-CoA:diacy Iglycerol acyl transferase family in the oleaginous yeast Yarrowia lipolytica. New insights into the storage lipid metabolism of oleaginous yeasts. Appl. Microbiol. Biot., v. 93, p. 1523-1537, 2012.

BOZAQUEL-MORAIS, B.L.; MADEIRA, J. B.; MAYA-MONTEIRO, C.M.; MASUDA, C.A.; MONTERO-LOMELI, M. A new fluorescence-based method identifies protein phosphatases regulating lipid droplet metabolism. PLoSOne. Oct28;5(10):e13692, 2010.

BROWN, B. D.; HSU, K. H.; HAMMOND, E. G.; GLATZ, B. A. A relationship between growth and lipid accumulation in Candida curvata D. J. biosci. bioeng., v. 68, p. 344-352, 1989.

CELIŃSKA, E.; GRAJEK, W. A novel multigene expression construct for modification of glycerol metabolism in Yarrowia lipolytica. Microb. Cell Fact., v.12,.p. 102, 2013.

CESCUT, J. Accumulation d'acylglycérols par des espèces levuri-ennes à usage carburant aéronautique: physiologie et performance de procedés. 2009. 301 p. Tese (PhD Thesis). Institut national des sciences appliquées Université de Toulouse, Toulouse, 2009.

CIRIGLIANO, M. C.; CARMAN, G. M. Purification and Characterization of Liposan, a Bioemulsifier from Candida lipolytica. Appl. Environ. Microbiol., v. 50, p. 846850,1985 .

COELHO, M. A. Z.; AMARAL, P. F. F. Yarrowia lipolytica: an industrial workhorse. Belo current research, technology and education topics in applied microbiology and microbial biotechnology.p. 930-944, 2010.

CORBACHO, I.; TEIXIDO, F.;VELA'ZQUEZ, R.; HERNA'NDEZ, L. M.; OLIVERO, I. Standard YPD, even supplemented with extra nutrients, does not always compensate growth defects of Saccharomyces cerevisiae auxotrophic strains. Antonie Van Leeuwenhoek. v. 99, p. 591-600, 2011.

CZABANY T, ATHENSTAEDT K, DAUM G. Synthesis, storage and degradation of neutral lipids in yeast. Biochim. Biophys. Acta., v. 1771, p. 299-309, 2007.

DAUM, G.; LEES, N. D.; BARD, M.; DICKSON, R. Biochemistry, Cell Biology and Molecular Biology of Lipids of Saccharomyces cerevisiae.Yeast,v.14, p. 1471-1510, 1998.

DEIVE, F. J.; SANROMÁN, M. A.; LONGO, M. A. A comprehensive study of lipase production by Yarrowia lipolytica CECT 1240 (ATCC 18942): from shake flask to continuous bioreactor FRANCISCO. J. Chem. Technol. Biot.. v. 85, p. 258-266, 2010.

DELLA-BIANCA, B. E. Stress tolerance of Saccharomyces cerevisiae strains employed in the fuel ethanol production in Brazil. 2013, 126 p. Tese (Doutorado 
em Engenharia Química) Escola Politécnica da Universidade de São Paulo, São Paulo, 2013.

DELLA-BIANCA, B. E. E GOMBERT, A. K. Stress tolerance and growth physiology of yeast strains from the Brazilian fuel ethanol industry. Antonie van Leeuwenhoek, v.104, p. 1083-1095, 2013.

DULERMO, T., E NICAUD, J-M. Involvement of the G3P shuttle and b-oxidation pathway in the control of TAG synthesis and lipid accumulation in Yarrowia lipolytica. Metabolic., v.13, p. 482-491, 2011.

ENDRIZZI, A.; PAGOT,Y.; LE CLAINCHE,A.; NICAUD, J-M.; BELINL, J-M. Production of Lactones and Peroxisomal Beta-Oxidation in Yeasts. CRC crit. rev. biotechnol., v.16, p. 301-329, 1996.

FAKAS, S.; PAPANIKOLAOU, S.; GALIOTOU-PANAYOTOU, M.; KOMAITIS, M.; AGGELIS, G. Biochemistry and biotechnology of single cell oil. In: PANDEY, A., LARROCHE, CH., SOCCOL, C.R., DUSSAP, C.-G., New Horizons in Biotechnology. Asiatech Publishers Inc., 2009, New Delhi, India, p. 53-75

FEI, W.; ZHONG, L.; TA, M. T.; SHUI, G.; WENK, M. R.; YANG, H. The size and phospholipid composition of lipid droplets can influence their proteome. Biochem. Biophys. Res. Commun., v. 415, p. 455-462, 2011.

FERREIRA, T. F. Emprego de Yarrowia lipolytica na degradação de óleo cru. 2009. 122 p. Dissertação (Mestrado em Tecnologia de Processos Químicos e Bioquímicos) Escola de Química da Universidade Federal do Rio de Janeiro, Rio de Janeiro.

FICKERS, P.; BENETTI, P.-H.; WACHÉ, Y.; MARTY, A.; MAUERSBERGER, S.; SMIT ,M. S.; NICAUD, J.-M. Hydrophobic substrate utilisation by the yeast Yarrowia lipolytica, and its potential applications. FEMS Yeast Res., v. 5, p. 527-543, 2005.

FONTES, G. C.; AMARAL, P. F. F.; COELHO, M. A. Z. Revisão: Produção de biossurfactante por levedura. Quim. Nova, v. 31, No. 8, p. 2091-2099, 2008.

FÖRSTER, A.; AURICH, A.; MAUERSBERGER, S.; BARTH, G. Citric acid production from sucrose using a recombinant strain of the yeast Yarrowia lipolytica. Appl. Microbiol. Biot., v. 75, n. 6, p. 1409-1417, 2007.

FUJIMOTO T, OHSAKI Y, CHENG J, SUZUKI M, SHINOHARA Y. Lipid droplets: a classic organelle with new outfits. Histochem. Cell Biol., v.130, p. 263-279, 2008.

GUI, M.; LEE, K. T.; BHATIA, S. Feasibility of edible oil vs. nonedible oil vs. waste edible oil as biodiesel feedstock. Energy, v. 33, p. 1646-1653, 2008.

GILL, C.; HALL, M.; RATLEDGE, C. Lipid accumulation in an oleaginous yeast with possession of ATP: citrate lyase. Appl. Envir. Microbiol., v. 33, p. 231-239, 1977. 
GOMES, N.; AGUEDO, M.; TEIXEIRA, J.; BELO, I. Oxygen mass transfer in a biphasic medium: influence on the biotransformation of methyl ricinoleate into cdecalactone by the yeast Yarrowia lipolytica. Biochem. Eng. J., v. 35, p. 380-386, 2007.

HALL, M. J.; RATLEDGE, C. Lipid accumulation in an oleaginous yeast (Candida 107) growing on glucose under various conditions in a one- and two- stage conditions culture. Appl. Environ. Microbiol., 33(3):577. 1977.

HADDOUCHE, R.; DELESSERT, S.; SABIROVA, J.; NEUV' EGLISE, C.; POIRIER, Y.; NICAUD, J-M. Roles of multiple acyl-CoA oxidases in the routing of carbon low towards b-oxidation and polyhydroxyalkanoate biosynthesis in Yarrowia lipolytica. FEMS. Yeast Res., v. 10, p. 917-927, 2010.

HAGLER, A. N.; MENDONÇA-HAGLER, L. C. Candida lipolytica isolated from guanabara bay and its ability to grow in marine and estuarine conditions. Rev. bras. pesqui. med. biol., v. 12, p. 273-277, 1979.

HAEGLER, A.N.; MENDONÇA-HAEGLER, L. C. Yeasts from marine and estuarine waters with different levels of pollution in the state of Rio de Janeiro, Brazil. Appl. Environ. Microbiol, v. 41, p. 173-178, 1981.

HASSLACHER, M.; IVESSA, A. S.; PALTAUF, F.; KOHLWEIN, S. D. Acetyl-CoA carboxylase from yeast is na essential enzyme and is regulayed by factors that control phospholipid metabolism. J. biol. chem., v.268, p. 10946-10952, 1993.

HOEK, P. V.; VAN DIJKEN, J. P.; PRONK, J. T. Effect of Specific Growth Rate on Fermentative Capacity of Baker's Yeast. Appl. Environ. Microbiol., v.64 p. 42264233, 1998.

HOLDSWORTH, J. E.; VEENHUIS, M.; RATLEDGE, C. Enzyme activities in oleaginous yeasts accumulating and utilizing exogenous or endogenous lipids. $\mathbf{J}$. Gen. Microbiol., v. 134, n.11, p. 2907-2915, 1988.

JUSZCZYK, P.; TOMASZEWSKA, L.; KITA, A.; RYMOWICZ, W. Biomass production by novel strains of Yarrowia lipolytica using raw glycerol, derived from biodiesel production. Bioresour. technol., v. 137, p. 124-131, 2013.

KAMISAKA, Y.; NODA, N.; SAKAI, T.; KAWASAKI, K. Lipid bodies and lipid body formation in an oleaginous fungus, Mortierella ramanniana var. angulispora. Biochim. Biophys. Acta., v. 1438, p. 185-198, 1999.

KAMZOLOVA, S. V.; SHISHKANOVA, N. V.; MORGUNOV, I. G.; FINOGENOVA, T. $\mathrm{V}$. Oxygen requirements for growth and citric acid production of Yarrowia lipolytica. FEMS Yeast Res., v. 3, p. 217-222, 2003.

KAMZOLOVA, S. V.; FATYKHOVA, A. R.; DEDYUKHINA, E. G.; ANASTASSIADIS, S. G.; GOLOVCHENKO, N. P.; MORGUNOV, I. G. Citric acid production by yeast grown on glycerol-containing waste from biodiesel industry. Food Technol. Biotech., v. 49, p. 65-74, 2011. 
KAMZOLOVA, S. V.; DEDYUKHINA, E. G.; SAMOILENKO, V. A.; LUNINA, J. N.; PUNTUS, I. F.; ALLAYAROV, R. L.; CHIGLINTSEVA, M. N.; MIRONOV, A. A.; MORGUNOV, I. G. Isocitric acid production from rapeseed oil by Yarrowia lipolytica yeast. Appl. Microbiol. Biot., v. 97, p. 9133-9144, 2013.

KIM, J-W; PARK, T. J.; RYU, D.D.Y.; Kim, J-Y. High Cell Density Culture of Yarrowia lipolytica Using a One-Step Feeding Process. Biotechnol. Prog., v.16, p. 657-660, 2000.

KLEINA, C. J. L.; OLSSONA, L.; NIELSENA, J. Nitrogen-limited continuous cultivations as a tool to quantify glucose control in Saccharomyces cerevisiae. Enzyme microb. technol., v. 23, p. 91-100, 1998.

LANGE, H. C.; HEIJNEN, J. J. Statistical reconciliation of the elemental and molecular biomass composition of Saccharomyces cerevisiae. Biotechnol Bioeng., v. 75, p. 334-344, 2001.

LARSSON, C.; VON STOCKAR, U.; MARISON, I.; GUSTAFSSON, L. Growth and metabolism of Saccharomyces cerevisiae in chemostat cultures under carbon-, nitrogen-, or carbon- and nitrogen-limiting conditions. J. Bacteriol., v. 175, p. 48094816, 1993.

LARSSON, C.; NILSSON, A.; BLOMBERG, A.; GUSTAFSSON, L. Glycolytic flux is conditionally correlated with ATP concentration in Saccharomyces cerevisiae: a chemostat study under carbon- or nitrogen-limiting conditions. J. Bacteriol., v. 179, p. 7243-7250, 1997.

LEITE, F. C. B.; BASSO, T. O.; PITA, W. B.; GOMBERT, A. K.; SIMO, D. A.; MORAIS, M. A. Quantitative aerobic physiology of the yeast Dekkera bruxellensis, a major contaminant in bioethanol production plants. FEMS Yeast Res., DOI: 10.1111/1567-1364.12007, 1-10, 2012.

LILLIE, S. H.; PRINGLE, J. R. Reserve carbohydrate metabolism in Saccharomyces cerevisiae: responses to nutrient limitation. J. Bacteriol., v. 43, p. 1384-1394, 1980.

LUTTIK, M. A.; KÖTTER, P.; SALOMONS, F. A.; VAN DER KLEI, I. J.; VAN DIJKEN, J. P.; PRONK, J. T. The Saccharomyces cerevisiae ICL2 gene encodes a mitochondrial 2-methylisocitrate lyase involved in propionyl-coenzyme A metabolism. J. bacteriol., v. 182, n. 24, p. 7007-13, dez. 2000.

LAZAR, Z.; ROSSIGNOL, T.; VERBEKE, J.; COQ, A. C.; NICAUD, J.; ROBAK, M. Optimized invertase expression and secretion cassette for improving Yarrowia lipolytica growth on sucrose for industrial applications. J. Ind. Microbiol. Biot., v. 40, p.1273-1283, 2013.

LAGES, F.; SILVA-GRAÇA, M.; LUCAS, C. Active glycerol uptake is a mechanism underlying halotolerance em yeasts: a study of 42 species. Microbiology, v. 145, p. 2577-2585, 1999. 
LUCIE MOELLER, L.; ZEHNSDORF, A.; AURICH, A.; BARTH, G. BLEY, T.; STREHLITZ, B. Citric acid production from sucrose by recombinant Yarrowia lipolytica using semicontinuous fermentation. Eng. Life Sci., v. 13, p. 163-171, 2013.

MADIGAN, M.T.; MARTINKO, J.M.; DUNLAP, P.V.; CLARK, D.P. Microbiologia de Brock. 12. ed., Porto Alegre, Artmed, 2010. 1160 p.

MASHEGO, M. R.; VAN GULIK, W. M.; VINKE, J. L.; HEIJNEN, J. J. Critical evaluation of sampling techniques for residual glucose determination in carbonlimited chemostat culture of Saccharomyces cerevisiae. Biotechnol. Bioeng., v. 83, p. 395-399, 2003.

MASON, J. T.; O'LEARY, T. J. Effects of formaldehyde fixation on protein secondary structure: a calorimetric and infrared spectroscopic investigation. J. histochem. cytochem., v. 39, n. 2, p. 225-229, 1991.

MLICKOVA, K.; ROUX, E.; ATHENSTAEDT, K.; D'ANDREA, S.; DAUM, G.; CHARDOT, T.; NICAUD, J. M. Lipid accumulation, lipid body formation, and acyl coenzyme-A oxidases of the yeast Yarrowia lipolytica. Appl. Environ. Microbiol., v. 70, p. 3918-3924, 2004.

MONOD, J. The growth of bacterial cultures. Annu. Rev. Microbiol., v. 3, p. 371394, 1949.

MOO-YOUNG, M. Comprehensive Biotechnology: The Principles, Applications and Regulations of Biotechnology in Industry, Agriculture and Medicine. V. 1 The Principles of Biotechnology: Scientific Fundamentals, Pergamon Press, Oxford, 1985.

MORGUNOV, I. G.; KAMZOLOVA, S. V.; LUNINA, J. N. The citric acid production from raw glycerol by Yarrowia lipolytica yeast and its regulation. Appl. Microbiol. Biot., v.97, p. 7387-7397, 2013.

MORITA, T.; KONISH, M.; FUKUOKA, T.; IMURA, T.; KITAMOTO, H. K.; KITAMOTO, D. Characterization of the genus Pseudozyma by the formation of glycolipid biosurfactants, mannosylerythritol lipids. FEMS Yeast Res., v.7, p. 286292. 2006.

MURPHY, D. J. Review: The biogenesis and functions of lipid bodies in animals, plants and microorganisms. Prog. lipid res., v. 40,p. 325-438, 2001.

NELSON, D. L.; COX, M. M. Lehninger Principles of Biochemistry. 4th ed. USA. W. H. Freeman \& Company, 2004.

NICAUD, J. M.; MADZAK, C.; VAN DEN BROEK, P.; GYSLER, C.; DUBOC, P.; NIEDERBERGER, P.; GAILLARDIN, C. Protein expression and secretion in the yeast Yarrowia lipolytica. FEMS Yeast Res., v. 2, n. 3, p. 371-9, ago. 2002.

NILSEN, J.; VILLADSEN, J. Bioreaction engeneering principles. Plenum Press, 2 ed., New York, 1994. 
OCHOA-ESTOPIER, A.; GUILLOUET, S. E. D-stat culture for studying the metabolic shifts from oxidativemetabolism to lipid accumulation and citric acid production in Yarrowia lipolytica. J. biotechnol.. v. 170, p. 35- 41, 2014.

OLIVEIRA, A. A. C. Estudo fisiológico e morfológico da aplicação de estresse eletroquímico em cultivos de levedura. 2009, 101 p. Dissertação (Mestrado em tecnologia de processos químicos e bioquímicos) Escola de Química da Universidade Federal do Rio de Janeiro, Rio de Janeiro, 2009.

OLIVEIRA, P. H. S. Análise fisiológica e cinética do crescimento da levedura oleaginosa Yarrowia lipolytica IMUFRJ 50682 em diferentes fontes de carbono. 2014, 121 p. Dissertação (Mestrado em Engenharia Quimica) Escola Politécnica da Universidade de São Paulo, São Paulo, 2014.

OLSSON, L.; NIELSEN, J. On-line and in situ monitoring of biomass in submerged cultivations. Tib. Tech., v. 15, p. 517-522, 1997.

PAPANIKOLAOU, S.; CHEVALOT, I.; KOMAITIS, M.; AGGELIS, G.; MARC, I. Kinetic profile of the cellular lipid composition in an oleaginous Yarrowia lipolytica capable of producing a cocoa-butter substitute from industrial fats. Antonie van Leeuwenhoek, v. 80, n. 3-4, p. 215-224, 2001.

PAPANIKOLAOU, S.; MUNIGLIA, L.; CHEVALOT, I.; AGGELIS, G.; MARC, I. Yarrowia lipolytica as a potential producer of citric acid from raw glycerol. Society, p. 737-744, 2002.

PAPANIKOLAOU S, AGGELIS G. Lipid production by Yarrowia lipolytica growing on industrial glycerol in a single-stage continuous culture. Bioresour. technol., v. 82, p. 43-49, 2002.

PAPANIKOLAOU S, AGGELIS G. Modeling lipid accumulation and degradation in Yarrowia lipolytica cultivated on industrial fats. Curr. Microbiol., v. 46, p. 398-402, 2003.

PAPANIKOLAOU, S.; GALIOTOU-PANAYOTOU, M.; CHEVALOT, I.; KOMAITIS, M.; MARC, I.; AGGELIS,G. Influence of glucose and saturated free-fatty acid mixtures on citricacid and lipid production by Yarrowia lipolytica. Curr. Microbiol., v. 52, p. 134142, 2006.

PAPANIKOLAOU, S.; FAKAS, S.; FICK, M.; CHEVALOT, I.; GALIOTOUPANAYOTOU, M.; KOMAITIS, M.; MARC, I.; AGGELIS, G. Biotechnological valorisation of raw glycerol discharged after bio-diesel (fatty acid methyl esters) manufacturing process: Production of 1,3-propanediol, citric acid and single cell oil. Biomass Bioenergy, v.32, p. $60-71,2008$.

PAPANIKOLAOU, S.; CHATZIFRAGKOU, A.; FAKAS, S.; GALIOTOUPANAYOTOU, M.; KOMAITIS, M.; NICAUD, J-M.; AGGELIS, G. Biosynthesis of lipids and organic acids by Yarrowia lipolytica strains cultivated on glucose. Eur. J. Lipid Sci. Technol, v. 111, p.1221-1232, 2009. 
PARROU, J. L.; ENJALBERT, B.; PLOURDE, L.; BAUCHE, A.; GONZALEZ, B.; FRANÇOIS, J. Dynamic responses of reserve carbohydrate metabolism under carbon and nitrogen limitations in Saccharomyces cerevisiae. Yeast., v.15, p. 191203, 1999.

PIRT, S. J. The maintenance energy of bactéria in growing cultures. Proc. R. Soc. Lond., v. 163, p. 264-231, 1965.

PIRT, S. J. Principles of Microbe and Cell Cultivation. A Halsted Press Book, John Wiley \& Sons, 1 ed. Nova York, 1975.

RATLEDGE, C. Yeasts, moulds, algae and bacteria as sources of lipids. In: KAMEL, B.S. and KAKUDA, Y. Technological Advances in Improved and Alternative Sources of Lipids. London: Blackie Academic and Professional, 1994. Cap. 9, p. 235-291.

RECH, F. R. Efeito do glicerol residual e carreadores de oxigênio sobre a produção de lipases de Staphylococus warneri. 2011. 67 p. Dissertação (Mestrado em Ciência e Tecnologia de Alimentos), Universidade Federal do Rio Grande do Sul, Porto Alegre.

REGENBERG,B.; GROTKJAER, T.; WINTHER, O.; FAUSBOLL, A.; AKESSON, M.; BRO, C.; HANSEN, L. K.; BRUNA, S.; NIELSEN, J. Growth-rate regulated genes have profound impact on interpretation of transcriptome profiling in Saccharomyces cerevisiae. Genome Biol., v.7, artigo R107 (doi:10.1186/gb-2006-7-11-r107), 2006.

RYWIN'SKA, A.; WOJTATOWICZ, M.; RYMOWICZ, W. Citric acid biosynthesis by Yarrowia lipolytica A-101-1.31 under deficiency of various medium macrocomponents. Elec. J. Polish Agric. Univ., v. 9, p. 1-9, 2006.

RYWIN'SKA, A.; RYMOWICZ, W.; ZAROWSKA, B.; SKRZYPIN'SKI, A. Comparison of citric acid production from glycerol and glucose by different strains of Yarrowia lipolytica. World J. Microb. Biot., v. 26, p. 1217-1224, 2010.

RYWIN'SKA, A.; JUSZCZYK, P.;WOJTATOWICZ, M.; RYMOWICZ, W. Chemostat study of citric acid production from glycerol by Yarrowia lipolytica. J. Biotech., v. 152, p. 54-57, 2011.

SABIROVA, J. S.; HADDOUCHE, R.; VAN BOGAERT, I. N.; MULAA, F.; VERSTRAETE, W.; TIMMIS, K. N.; SCHMIDT-DANNERT, C.; NICAUD, J. M.; SOETAERT, W. The 'LipoYeasts' project: using the oleaginous yeast Yarrowia lipolytica in combination with specific bacterial genes for the bioconversion of lipids, fats and oils into high-value products. Microb. Biot., v. 4, p. 47-54, 2011.

SCHMIDELL, W.; LIMA, U. A.; AQUARONE, E.; BORZANI, W. Biotecnologia Industrial: Engenharia Bioquimica.v.2, 1 ed. Edgard Blücher. São Paulo, 2001. 
SEIP, J.; JACKSON, R.; HE, H.; ZHU, Q.; HONG, S-P. Snf1 Is a Regulator of Lipid Accumulation in Yarrowia lipolytica. Appl. Environ. Microbiol., v. 79, n. 23, p. 73607370, 2013.

SZABO, R. Dimorphism in Yarrowia lipolytica: Filament Formation Is Suppressed by Nitrogen Starvation and Inhibition of Respiration. Folia Microbiol., v. 44, p. 19-24, 1999.

TAI, M. E.; STEPHANOPOULOS, G. Engineering the push and pull of lipid biosynthesis in oleaginous yeast Yarrowia lipolytica for biofuel production. Metab. Eng., v. 15, p. 1-9, 2013.

TEHLIVETS, O.; SCHEURINGER, K.; KOHLWEIN, S. D. Review: Fatty acid synthesis and elongation in yeast. Biochemistry, Biochim. Biophys. Acta, Mol. Cell Biol. Lipids, v. 1771, v. 255-270, 2007.

TER SCHURE E. G.; SILLJÉ, H. H.; RAEVEN, L. J.; BOONSTRA, J.; VERKLEIJ, A. J.; VERRIPS, C.T. Nitrogen-regulated transcription and enzyme activities in continuous cultures of Saccharomyces cerevisiae. Microbiology, v. 141, p. 11011108, 1995a.

TER SCHURE E. G.; SILLJÉ, H. H.; VERKLEIJ, A. J.; BOONSTRA, J.; VERRIPS, C.T. The concentration of ammonia regulates nitrogen metabolism in Saccharomyces cerevisiae. J. Bacteriol., v. 177, p. 6672-6675, 1995b.

TER SCHURE, E. G.; SILLJÉ, H. H.; VERMEULEN, E. E.; KALHORN, J. W.; VERKLEIJ, A. J.; BOONSTRA, J.; VERRIPS, C. T. Repression of nitrogen catabolic genes by ammonia and glutamine in nitrogen-limited continuous cultures of Saccharomyces cerevisiae. Microbiology, v. 144, p. 1451-1462, 1998.

TSIGIE, Y. A.; WANGA, C.; TRUONG, C.; JU, Y. Lipid production from Yarrowia lipolytica Po1g grown in sugarcane bagasse hydrolysate. Bioresour. technol., v.102, p. 9216-9222, 2011.

TSUGAWA, R.; NAKASE, T.; KOYABASHI, T.; YAMASHITA, K.; OKUMURA, S. Fermentation of $n$-paraffins by yeast. Part III. K-Ketoglutarate productivity of various yeasts. Agr. Biol. Chem., Tokyo, v.33, p. 929-938, 1969.

VERDUYN, C.; POSTMA, E.; SCHEFFERS, W. A.; VAN DIJKEN, J. P. Effect of benzoic acid on metabolic fluxes in yeasts: A continuous-culture study on the regulation of respiration and alcoholic fermentation. Yeast, v. 8, n. 7, p. 501-517, 1992.

XUE, Z.; SHARPE, P. L.; HONG, S. P.; YADAV, N. S.; XIE, D.; SHORT, D. R.; DAMUDE, H. G.; RUPERT, R. A.; SEIP, J. E.; WANG, J.; POLLAK, D. W.; BOSTICK, M. W.; BOSAK, M. D.; MACOOL, D. J.; HOLLERBACH, D. H.; ZHANG, H.; ARCILLA, D. M.; BLEDSOE, S. A.; CROKER, K.; MCCORD, E. F.; TYREUS, B. D.; JACKSON, E. N.; ZHU, Q. Production of omega-3 eicosapentaenoic acid by metabolic engineering of Yarrowia lipolytica. Nat. Biotechnol., v. 31, p. 734-740, 2013. 
YANG, H.; GALEA, A.; SYTNYK, V.; CROSSLEY, M. Controlling the size of lipid droplets: lipid and protein factors. Curr. opin. cell biol., v. 24, p. 509-516, 2012.

YKEMA, A.; VERBREE, E. C.; VERSEVELD, H. W.; SMIT, H. Mathematical modelling of lipid production by oleaginous yeasts in continuous cultures. Antonie Van Leeuwenhoek, v. 52, p. 491-506, 1986.

ZHANG, Y.; ADAMS, I. P.; RATLEDGE, C. Malic enzyme: the controlling activity for lipid production? Overexpression of malic enzyme in Mucor circinelloides leads to a 2.5-fold increase in lipid accumulation. Microbiology, v. 153, n. 7, p. 2013-2025, 2007.

ZHANG, J.; GREASHAM, R. Chemically defined media for commercial fermentations. Appl. Microbiol. Biot., v. 51, p. 407-422, 1999.

ZHU, F.; TAJKHORSHID, E.; SCHULTEN, K. Pressure-induced water transport in membrane channels studied by molecular dynamics. Biophys. J., v. 83, p. 154-160, 2002.

ZWEYTICK, D.; ATHENSTAEDT, K.; DAUM, G. Intracellular lipid particles of eukaryotic cells. Biochim. Biophys. Acta, Mol. Cell Biol. Lipids., v.1469, p. 101120, 2000.

WANG, H. J.; LE DALL, M. T.; WACHÉ, Y.; LAROCHE, C.; BELIN, J. M.; GAILLARDIN, C.; NICAUD, J. M. Evaluation of acyl coenzyme A oxidase (Aox) isozyme function in the $\mathrm{n}$-alkane-assimilating yeast Yarrowia lipolytica. J. Bacteriol., v. 181, p. 5140-5148, 1999.

WANG, Z.-P; XU, H-M.; WANG, G-Y.; CHI, Z.; CHI, Z-M. Disruption of the MIG1 gene enhances lipid biosynthesis in the oleaginous yeast Yarrowia lipolytica ACA-DC 50109. Biochim. Biophys. Acta, Mol. Cell Biol. Lipids., v. 1831, p. 675-682, 2013.

WAITE, M.; WAKIL, S. J. Studies on the mechanism of fatty acid synthesis. XII. Acetyl Coenzyme A Carboxylase. J. Biol. Chem., v. 237, p. 2750-2757, 1962.

WEN, Z.; PYLE, D.; ATHALYE, S. Glycerol waste from biodiesel manufacturing. In: AGGELIS, G. Microbial Conversions of Raw Glycerol. New York: Nova Science Publishers Inc., 2009, cap. 1, p. 1-7.

WOLINSKI, H. E; KOHLWEIN, S. D. Microscopic analysis of lipid droplet metabolism and dynamics in yeast. Methods. Mol. Biol., v. 457, p. 151-163, 2008.

WORKMAN, M.; HOLT, P.; THYKAER, J. Comparing cellular performance of Yarrowia lipolytica during growth on glucose and glycerol in submerged cultivations. AMB Express, v. 3, p. 58, 2013.

WU, L.; GE, G.; WAN, J. Biodegradation of oil wastewater by free and immobilized Yarrowia lipolytica W29. J. Environ. Sci., v. 21, p. 237-242, 2009. 


\section{APÊNDICE A - Determinação do fator de conversão substrato a célula dos cultivos realizados.}

Y x/s IMUFRJ A

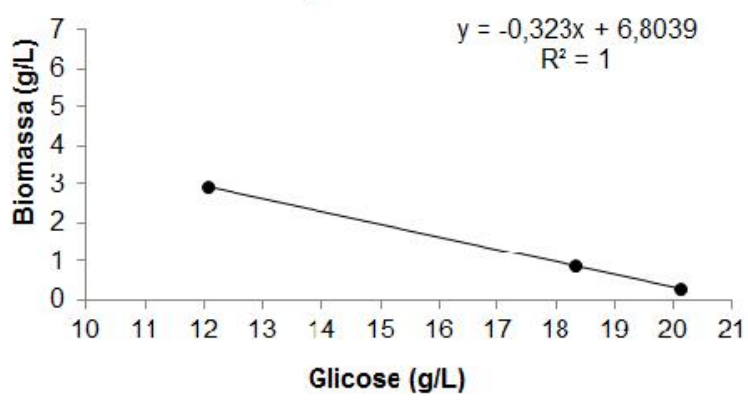

Y x/s W29 A

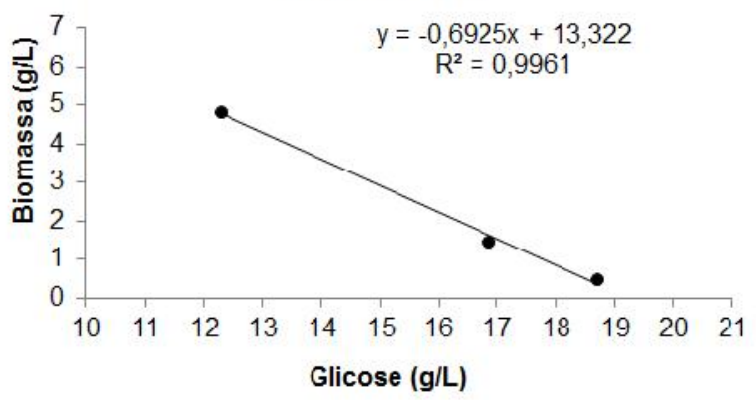

Y $\mathrm{x} / \mathrm{s}$ IMUFRJ B

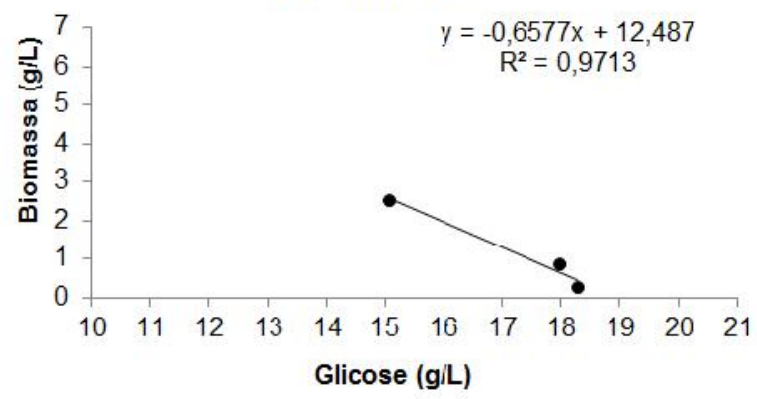

Y x/s W29 B

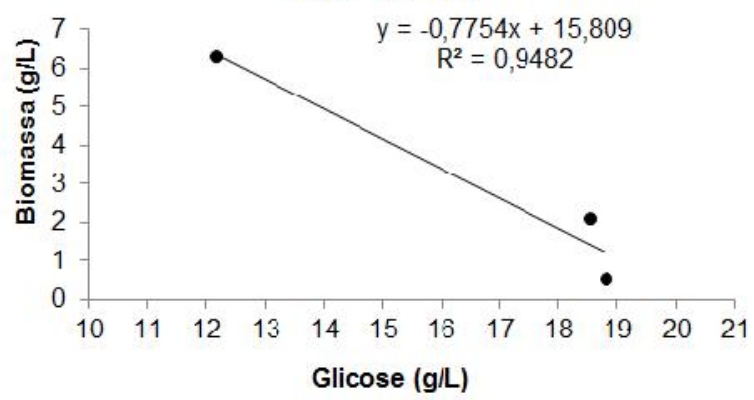

Figura 25 - Regressões lineares para obtenção dos fatores de conversão do substrato a biomassa seca na fase exponencial $\left(Y_{X / 5}^{\exp }\right)$ dos cultivos em frasco (Tabela 4), em meio definido BARTH, com a fonte de carbono glicose. Cultivos realizados a $28{ }^{\circ} \mathrm{C}$, agitação de $250 \mathrm{rpm}$ com fonte de carbono glicose (20 $\mathrm{g} / \mathrm{L}$ iniciais) e fonte de nitrogênio sulfato de amônio ( $3 \mathrm{~g} / \mathrm{L}$ iniciais), com a relação $\mathrm{C} / \mathrm{N}(\mathrm{g} / \mathrm{g})$

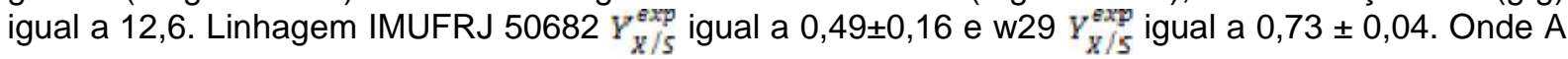
e B são duplicatas. 
Y x/s IMUFRJ A

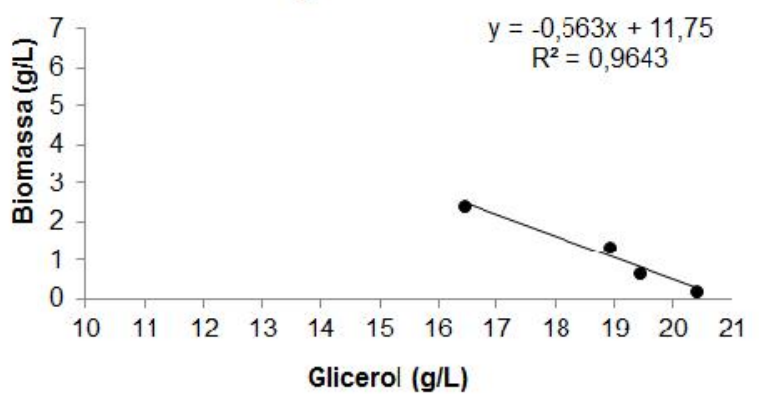

Y x/s W29 A

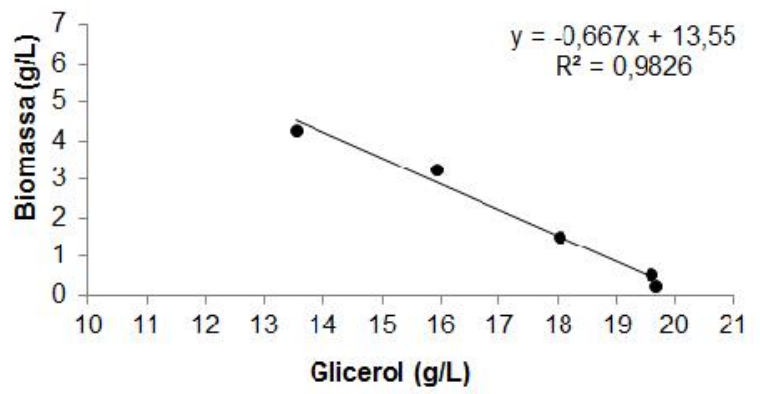

Y x/s IMUFRJ B

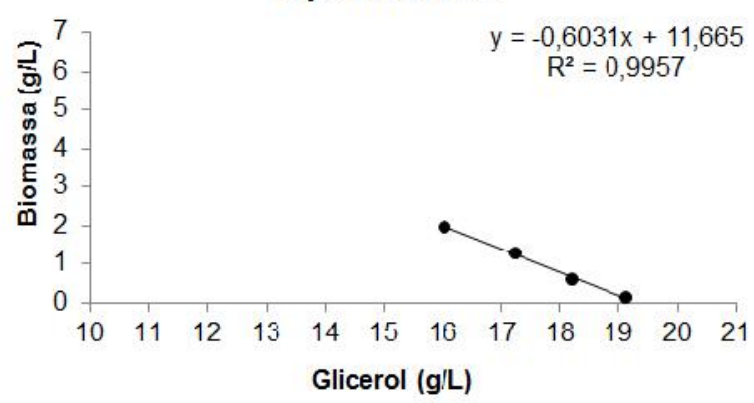

Y x/s W29 B

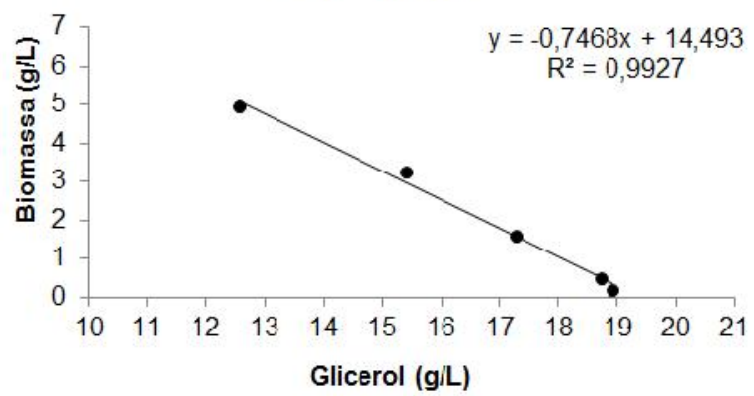

Figura 26 - Regressões lineares para obtenção dos fatores de conversão do substrato a biomassa seca na fase exponencial $\left(Y_{X / 5}^{\exp }\right)$ dos cultivos em frasco (Tabela 4), em meio definido BARTH, com a fonte de carbono glicerol. Cultivos realizados a $28{ }^{\circ} \mathrm{C}$, agitação de $250 \mathrm{rpm}$ com fonte de carbono glicerol (21 g/L iniciais) e fonte de nitrogênio sulfato de amônio (3 g/L iniciais), com a relação C/N

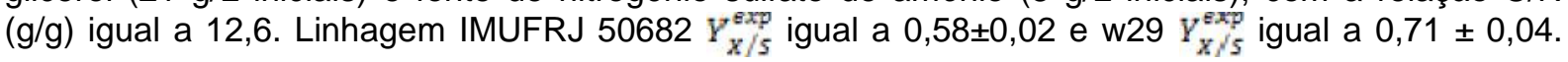
Onde A e B são duplicatas.

\section{$\mathrm{Y} x / \mathrm{s}$ IMUFRJ}

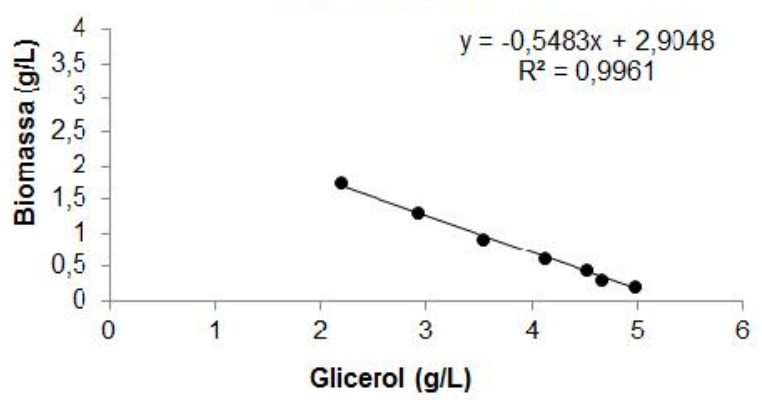

Y x/s W29

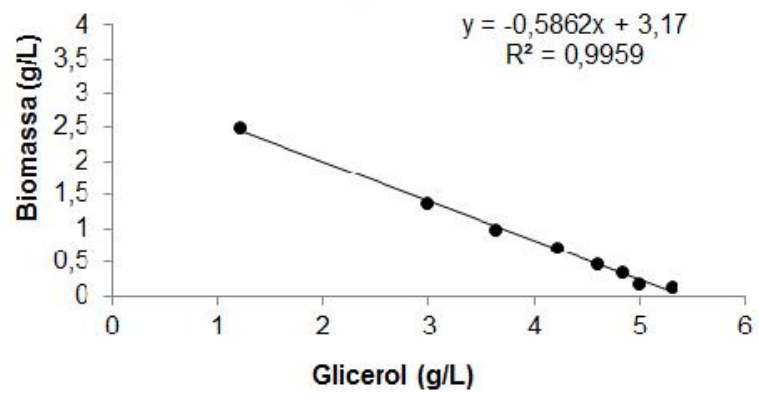

Figura 27 - Regressões lineares para obtenção dos fatores de conversão do substrato a biomassa seca na fase exponencial $\left(Y_{X / 5}^{\operatorname{sxp}}\right)$ dos cultivos em biorreator (Tabela 9), em meio definido BARTH, com a fonte de carbono glicerol. Cultivo em batelada em biorreator de $1 \mathrm{~L}$, a $28{ }^{\circ} \mathrm{C}, \mathrm{pH} 5$, agitação 1000 $\mathrm{rpm}, 0,3 \mathrm{~mL} / \mathrm{L}$ de antiespumante, ar comprimido a $1 \mathrm{vvm}$ e $5 \mathrm{~g} / \mathrm{L}$ iniciais de glicerol como fonte de carbono. Relação C/N (g/g) inicial igual a 3. Linhagem IMUFRJ $50682 Y_{X / 5}^{\exp }$ igual a 0,55 e w29 $Y_{X / 5}^{\exp }$ igual a 0,59 . 
Y x/s W29 A

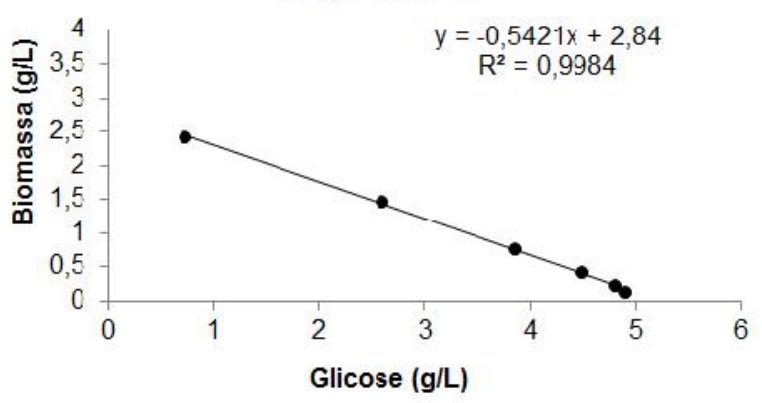

Y x/s W29 B

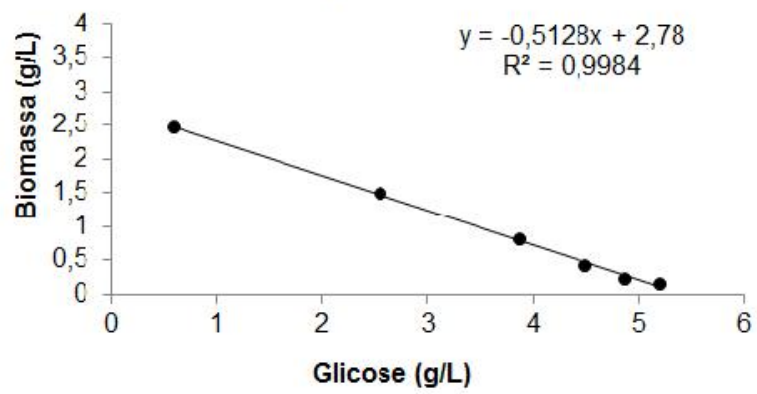

Figura 28 - Regressões lineares para obtenção dos fatores de conversão do substrato a biomassa seca na fase exponencial $\left(Y_{X / S}^{\exp }\right)$ dos cultivos em biorreator (Tabela 9), em meio definido BARTH, com a fonte de carbono glicose. Cultivo em batelada em biorreator de $1 \mathrm{~L}$, a $28^{\circ} \mathrm{C}, \mathrm{pH} 5$, agitação 1000 $\mathrm{rpm}, 0,3 \mathrm{~mL} / \mathrm{L}$ de antiespumante, ar comprimido a $1 \mathrm{vvm}$ e $5 \mathrm{~g} / \mathrm{L}$ iniciais de glicose como fonte de

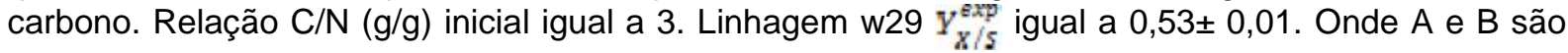
duplicatas.

\section{Y x/s IMUFRJ}

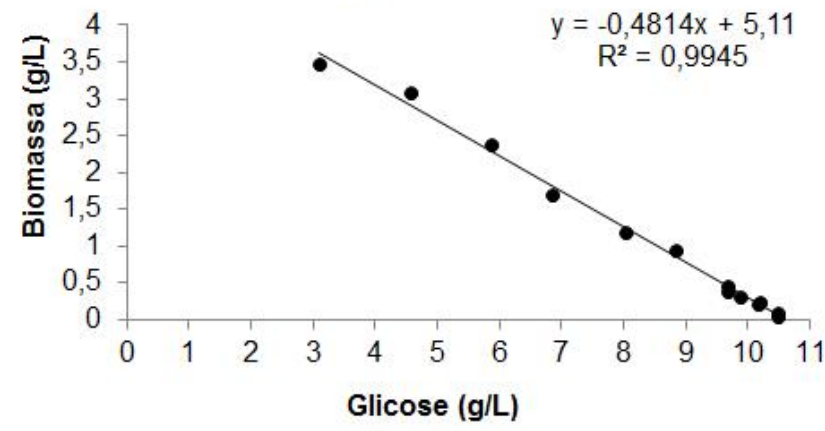

Figura 29 - Regressões lineares para obtenção dos fatores de conversão do substrato a biomassa seca na fase exponencial $\left(Y_{X / 5}^{s x p}\right)$ dos cultivos em biorreator (Tabela 9), em meio definido BARTH, com a fonte de carbono glicose. Cultivo em batelada em biorreator de $1 \mathrm{~L}$, a $28^{\circ} \mathrm{C}, \mathrm{pH} 5$, agitação 1000 $\mathrm{rpm}, 0,3 \mathrm{~mL} / \mathrm{L}$ de antiespumante, ar comprimido a $1 \mathrm{vvm}$ e $10 \mathrm{~g} / \mathrm{L}$ iniciais de glicose como fonte de carbono. Relação C/N (g/g) inicial igual a 6,25. Linhagem IMUFRJ $50682 Y_{x / 5}^{\exp }$ igual a 0,48. 


\section{APÊNDICE B - Cromatogramas inicial e final de um cultivo}

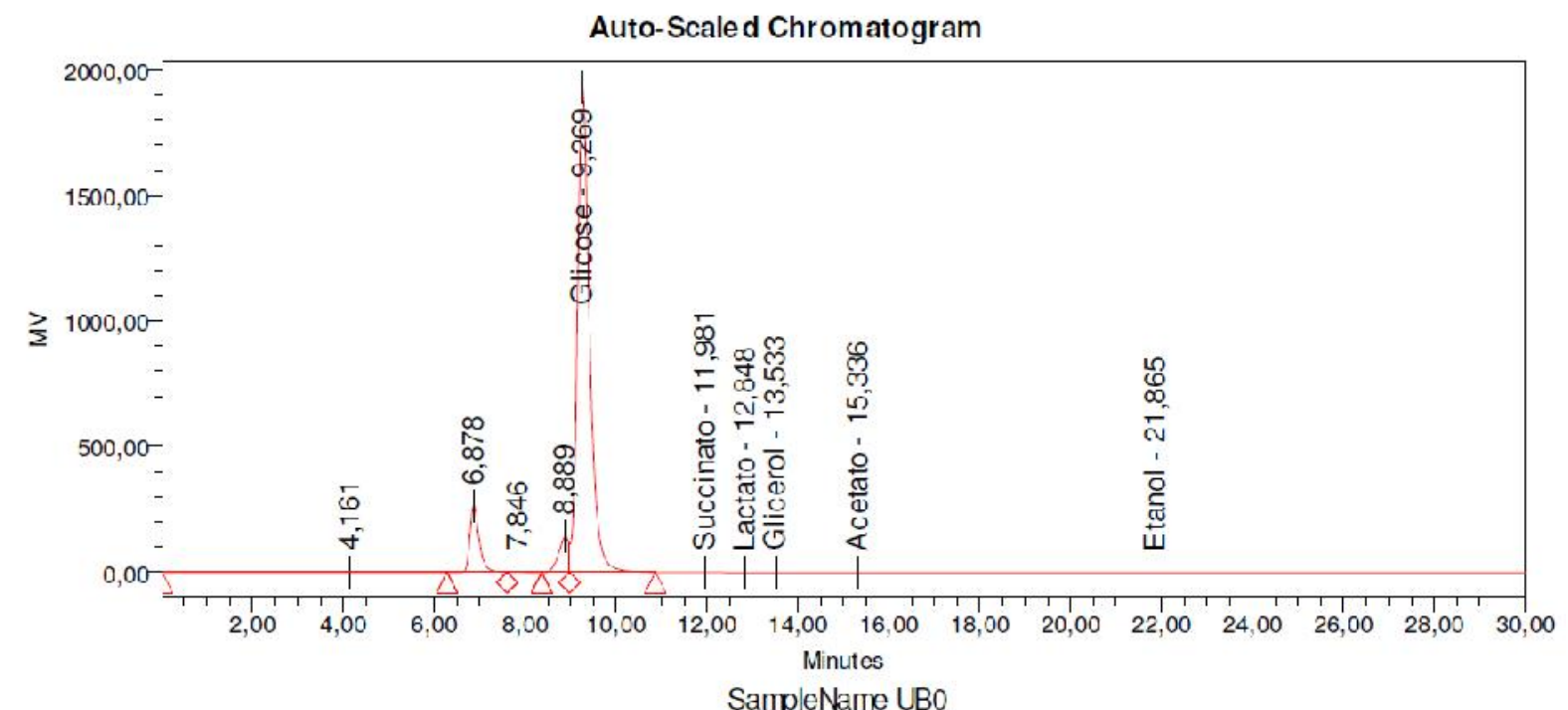

Figura 30 - Cromatograma de uma amostra no instante inicial de um cultivo com a fonte de carbono glicose.

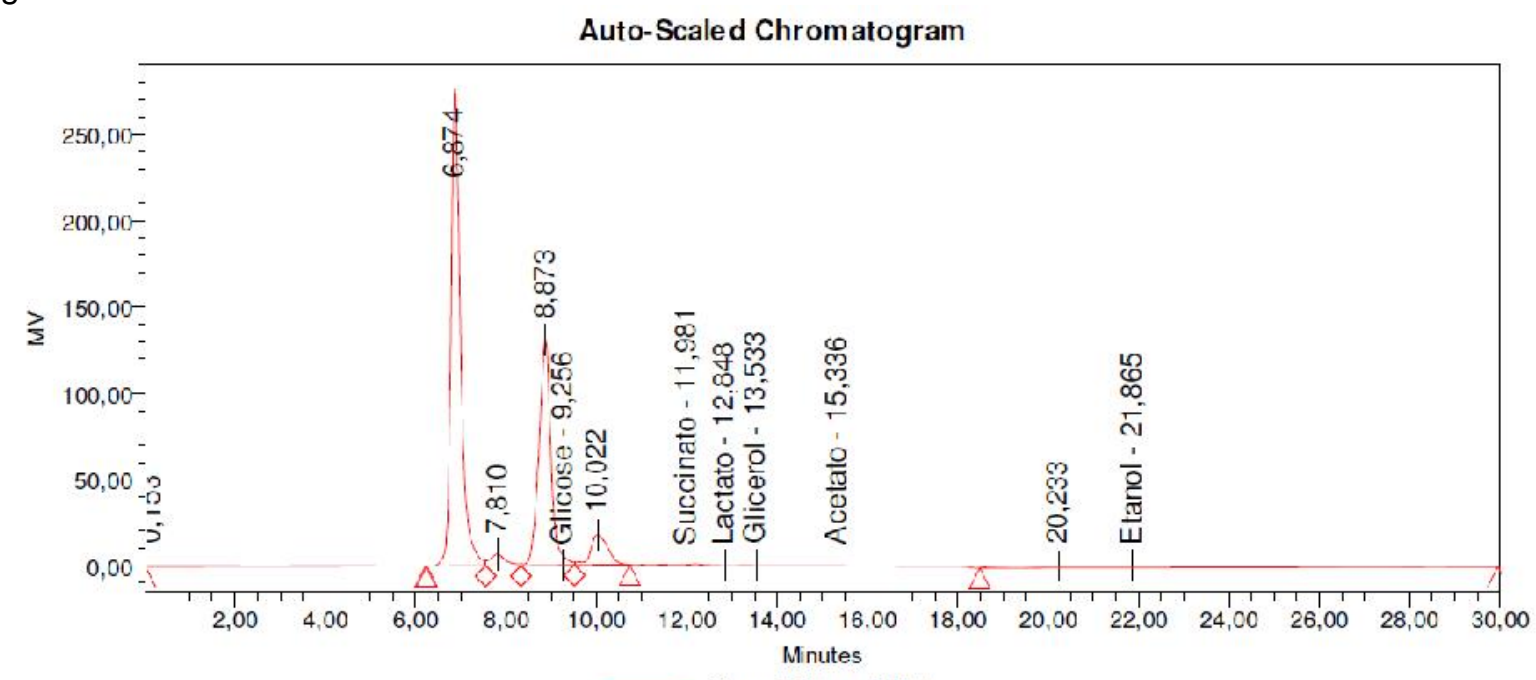

SampleName UB11

Figura 31- Cromatograma de uma amostra no instante final de um cultivo com a fonte de carbono glicose, mostrando a glicose esgotada e nenhum outro metabólito produzido. 